\title{
Regulator of G Protein Signaling-21 (RGS21) in Peripheral Taste Physiology.
}

\author{
Adam Bryant Schroer
}

Follow this and additional works at: https://researchrepository.wvu.edu/etd

\section{Recommended Citation}

Schroer, Adam Bryant, "Regulator of G Protein Signaling-21 (RGS21) in Peripheral Taste Physiology." (2018). Graduate Theses, Dissertations, and Problem Reports. 8187.

This Dissertation is protected by copyright and/or related rights. It has been brought to you by the The Research Repository @ WVU with permission from the rights-holder(s). You are free to use this Dissertation in any way that is permitted by the copyright and related rights legislation that applies to your use. For other uses you must obtain permission from the rights-holder(s) directly, unless additional rights are indicated by a Creative Commons license in the record and/ or on the work itself. This Dissertation has been accepted for inclusion in WVU Graduate Theses, Dissertations, and Problem Reports collection by an authorized administrator of The Research Repository @ WVU.

For more information, please contact researchrepository@mail.wvu.edu. 


\title{
Regulator of G protein signaling-21 (RGS21) in peripheral taste physiology
}

\section{Adam Bryant Schroer}

\author{
Dissertation submitted \\ to the School of Medicine \\ at West Virginia University \\ in partial fulfillment of the requirements for the degree of \\ Doctor of Philosophy in \\ Cellular \& Integrative Physiology
}

Eric E. Kelley, Ph.D., Chair David P. Siderovski, Ph.D.

Vincent Setola, Ph.D.

William T. Stauber, Ph.D.

Emidio E. Pistilli, Ph.D.

Department of Physiology, Pharmacology, and Neuroscience

Morgantown, West Virginia

2018

Keywords: regulator of G protein signaling-21 (RGS21), taste buds, taste perception Copyright 2018 Adam Bryant Schroer 


\section{ABSTRACT \\ Regulator of G protein signaling-21 (RGS21) in peripheral taste physiology}

\section{Adam Bryant Schroer}

The gustatory system subjects ingested food to 'quality control' that prevents consumption of harmful compounds while also regulating nutrient intake. A better understanding of the physiological regulation of taste will enhance our ability to facilitate the appropriate consumption of nutrients and improve overall health. Bitter, sweet, and umami tastes are detected by a family of G protein-coupled receptors (GPCRs) that associate with heterotrimeric $G$ proteins and initiate intracellular signaling cascades after activation by tastant binding. 'Regulators of G protein Signaling' (RGS proteins) act as G $\alpha$-directed GTPase-accelerating proteins (GAPs) and thereby accelerate inactivation of GPCR-mediated signaling. Rgs 21 is selectively expressed in tastantresponsive tissue, suggesting it likely facilitates the inactivation of the taste transduction pathway. We have assessed taste responses in Rgs21 knockout mice: bitterant, sweetener, and umami responses (metabotropic, Type II cell responses) are blunted in the absence of RGS21, whereas aversion to sour (ionotropic, Type III cell response) is unchanged. Notably, appetitive responses to $\mathrm{NaCl}$ are blunted in $\mathrm{Rgs} 21$-deficient mice as well, suggesting transduction of $\mathrm{NaCl}$ taste involves a GPCR and/or $\mathrm{G}$ protein signaling in Type II taste receptor cells. We suspect that RGS21 loss leads to hyperactivity of GPCRs in taste receptor cells, eventually causing prolonged desensitization and/or downregulation. Further work is needed to test this hypothesis and thus elucidate the mechanism(s) by which RGS21 affects peripheral taste signaling, including appetitive salt taste (a taste modality traditionally considered the exclusive domain of ionotropic signal transduction). 


\section{Acknowledgements}

My years at West Virginia University have been challenging, but also rewarding as I have diligently sought to launch my research career. Through my own personal efforts and with the help of my mentors, friends, and family, I have been able to refine my scientific skills and am ready for the next step in my career.

I would first like to thank David for his support and guidance throughout my time in his lab. His Canadian politeness and earnestness always motivated me to follow his example and give more to the lab. I am grateful for David's lightning fast responses to my emails, being a sounding board when I needed it, and his diligence in helping to further my training. I don't know how you keep everything straight with the many "hats" you wear within the University, but I am eternally grateful for your continued attention and mentorship as I seek to further my research career. Also, a special thanks to Sue for being understanding as David works persistently up to the $11^{\text {th }}$ hour to help everyone in the lab. Vince, I thank you for all the time you spent teaching me and challenging me to articulate and defend my ideas. These skills will be critical to my future career.

I would also like to thank the additional members of my dissertation committee: Dr. Emidio Pistilli, Dr. Eric Kelley, and particularly Dr. William Stauber for continuing to challenge and encourage me, whether in journal club, seminars, classes, or Starbucks.

To Bryan, Josh, and Shane, our discussions about everything from the ills of society to the healthfulness of frozen chicken are always intellectually stimulating. You always pushed me to find new ways to play devil's advocate. Having you all to decompress with and use as a sounding board helped to keep me sane (or at least close to it). I will always be thankful that I had you not just as lab mates, but also as friends. 
I also must thank Kayla, who has been one of my greatest supporters the past few years. She has made the lows less low and the highs more high during this pursuit.

Finally, I would like to thank my mom for her continued support and encouragement throughout my career. Her ability to support and nurture others is beyond what should be humanly possible. I also want to thank my family for their confidence in me to make the most of the opportunities that life has given me. I wish I could have made more trips to see them all during my time in graduate school, but I am grateful for their understanding and the time we spent together. 


\section{Table of Contents}

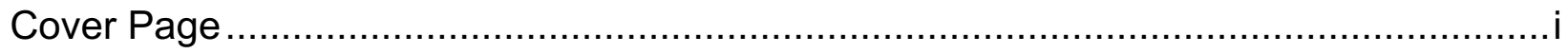

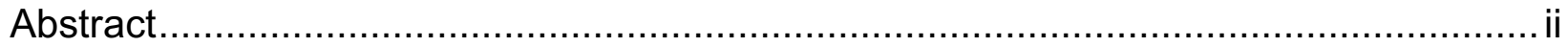

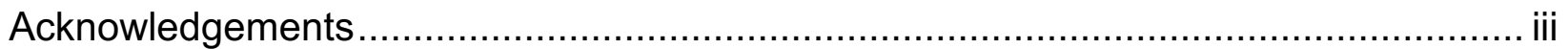

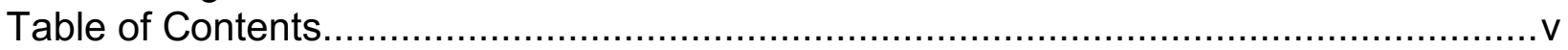

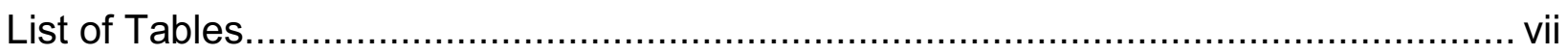

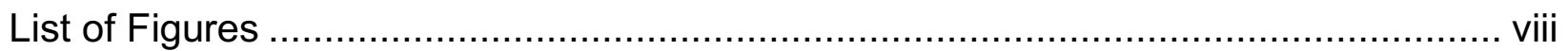

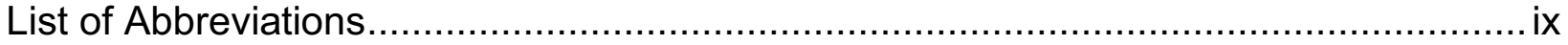

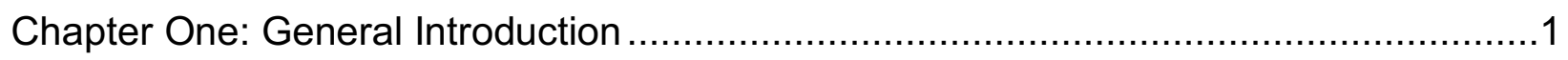

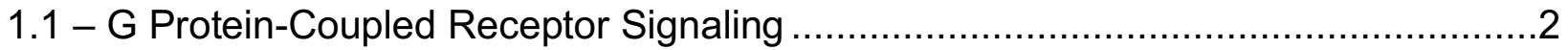

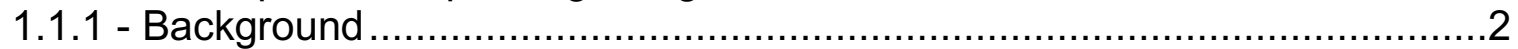

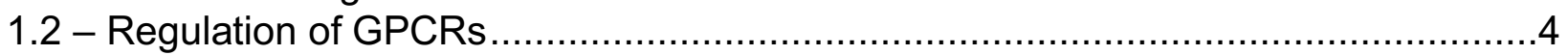

1.2.1a - Kinase-mediated Regulation ...................................................

1.2.1b - Kinase-mediated Regulation in Physiology .....................................

1.2.2a - Regulators of G protein Signaling (RGS proteins) ............................

1.2.2b - RGS proteins in Physiology......................................................11

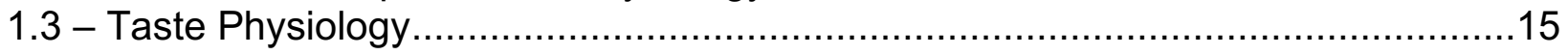

1.3.1 - Introduction to Taste Physiology .................................................15

1.3.2 - Regulator of G Protein Signaling-21 in Taste Physiology .....................20

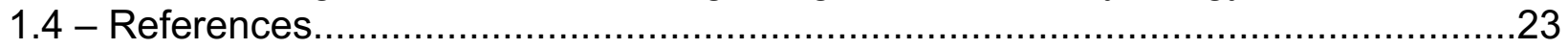

Chapter Two: Development of full sweet, umami, and bitter taste responsiveness requires Regulator of G protein Signaling-21 (RGS21) ..........................................

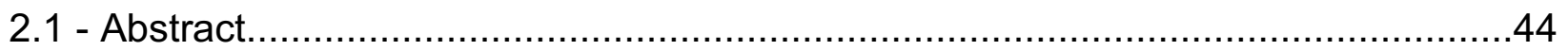

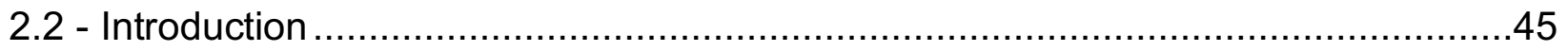

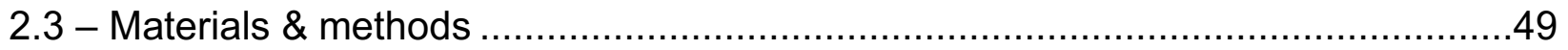

2.3.1 - Subjects \& maintenance ..........................................................

2.3.2 - RNA extraction.......................................................................50

2.3.3 - Real-time quantitative reverse transcription-polymerase chain reaction 51

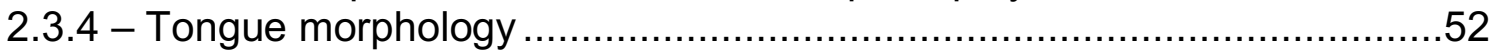

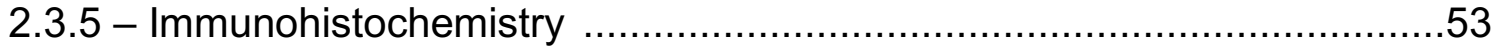

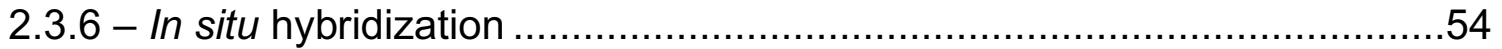

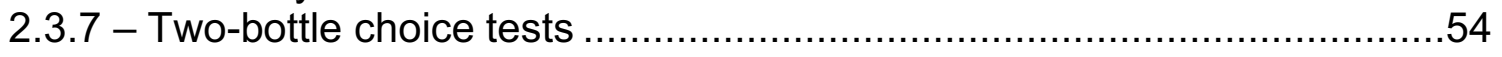

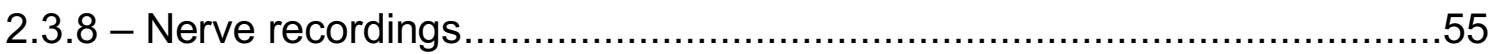

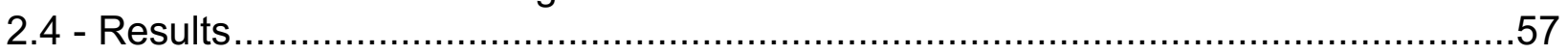

2.4.1 - Development of Rgs21-null mice ..........................................57

2.4.2 - Normal lingual histology and complement of taste cell-specific markers in

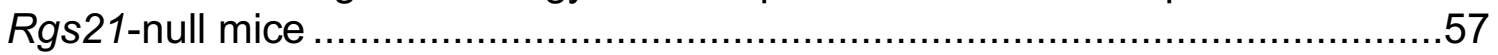

2.4.3 - Reduced responsiveness in two-bottle choice tests............................58

2.4.4 - Blunted responses in chorda tympani nerve recordings.......................59

2.5 - Discussion 


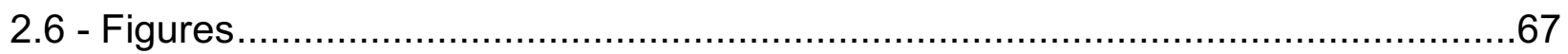

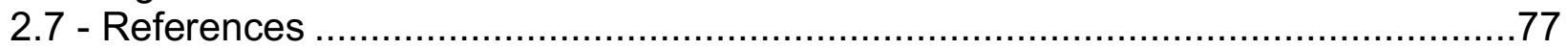

Chapter Three: Further investigations of RGS21 in taste physiology..........................86

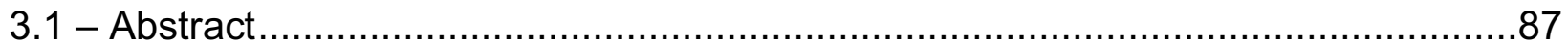

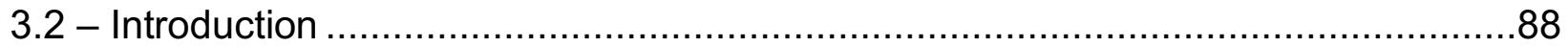

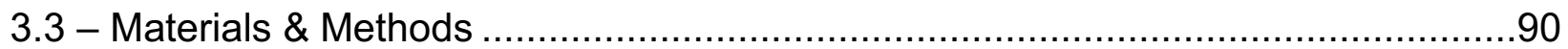

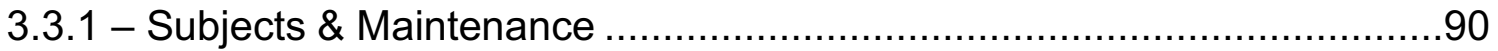

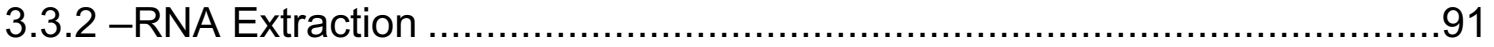

3.3.3 - Real-time quantitative reverse transcription-polymerase chain reaction.92

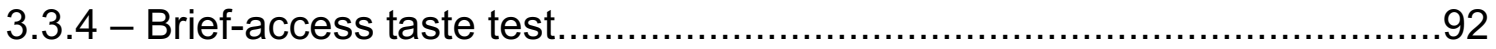

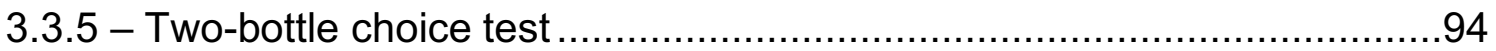

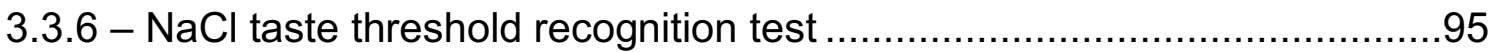

3.3.7 - Additional Rgs genes in taste receptor cells ...................................96

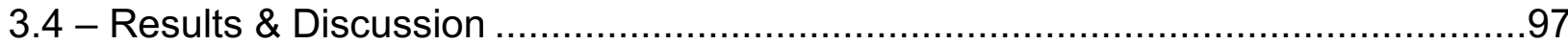

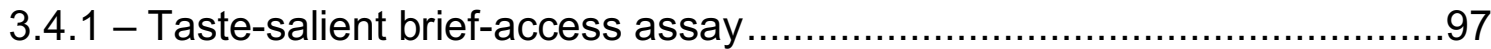

3.4.2 - Gene-dose effect of Rgs21 deficiency .........................................97

3.4.3 - Temporal function of RGS21 in taste responsiveness ........................99

3.4.4 - Understanding salt taste deficits in Rgs21-deficient mice ...................101

3.4.5 - Additional Rgs genes in taste receptor cells ..................................103

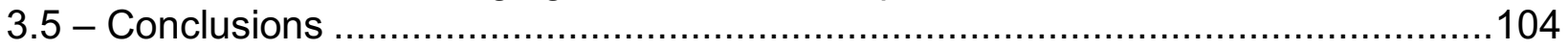

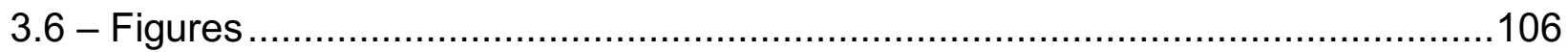

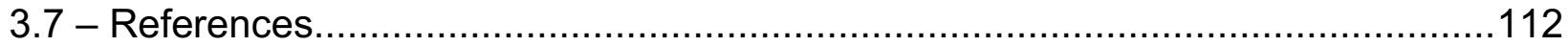

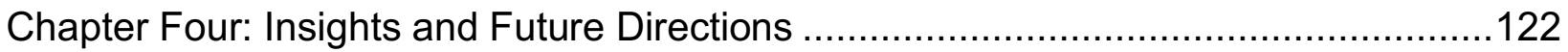

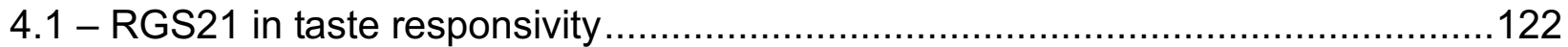

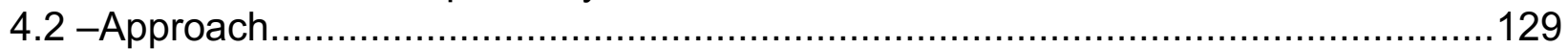

4.2.1 - Identify the roles of additional RGS proteins in taste responses ....................130

4.2.1a - Two-bottle choice tests ........................................................130

4.2.1b - Taste-salient brief-access taste tests ...................................... 132

4.2.1c - Nerve recordings .............................................................. 134

4.2.2 - Establish how RGS proteins affect peripheral taste signaling ........................139

4.2.2a - Characterize taste cell complement / morphology ..........................139

4.2.2b - Delineate the temporal influence of $R g s$ gene loss ......................... 142

4.2.2c - Testing for evidence of receptor downregulation............................142

4.2.2d - Second messenger production and ATP release assays..................144

4.2.2e - Interrogating the role of RGS proteins in salt taste .........................148

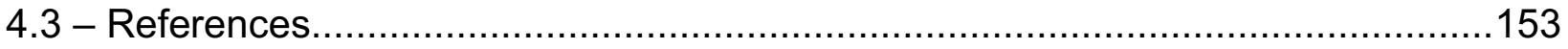




\section{List of Tables}

Fig. Title:

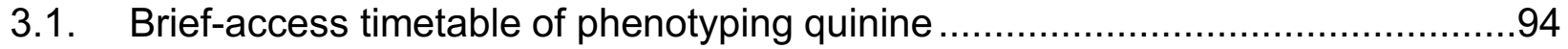

3.2. Brief-access timetable of phenotyping sucrose ...............................................94 


\section{List of Figures}

Fig. Title:

1.1. The guanine nucleotide cycle governing GPCR-mediated activation of

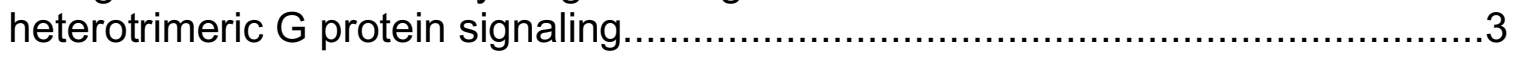

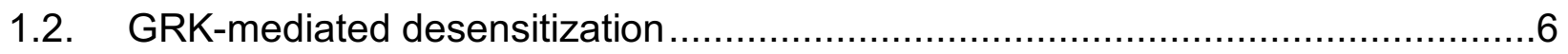

1.3. Representative members of the mammalian RGS protein subfamilies ..............14

1.4. Simplified model of the $\mathrm{G} \alpha \cdot \mathrm{GDP} / \mathrm{G} \alpha \cdot \mathrm{GTP}$ cycle controlled by tastant-responsive

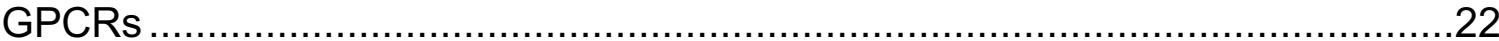

2.1. Genotype and gene expression validation of excision of Rgs21 exon 5............64

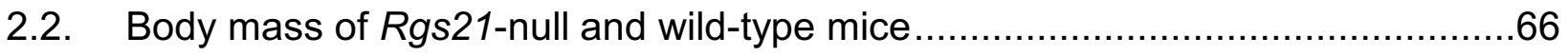

2.3. Tongue morphology in Rgs21-null mice ....................................................67

2.4. Morphology and expression of taste cell markers within circumvallate papillae of

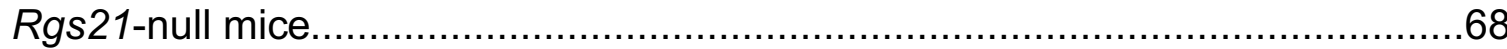

2.5. Two-bottle choice preferences of $\operatorname{Rgs} 21^{\Delta 5 / \Delta 5}(\mathrm{n}=7)$ and wild-type mice .............70

2.6. Representative integrated chorda tympani nerve responses in $R g s 21^{\Delta 5 / \Delta 5}$ mice.72

3.1. Brief-access taste tests using $R g s 21^{\Delta 5 / \Delta 5}$ mice and wild-type littermates ..........106

3.2. Two-bottle choice preferences of Rgs21-heterozygous mice..........................107

3.3. Two-bottle choice data of tamoxifen-induced Rgs21-deficient mice..................108

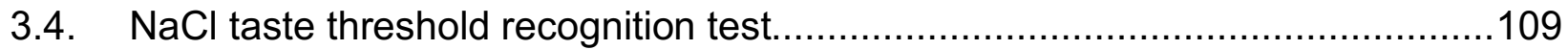

3.5. Two-bottle choice preferences of salts in $R g s 21^{\Delta 5 / \Delta 5}$ and wild-type mice..........110

3.6. Rgs genes differentially expressed in Tas $1 r 3+$ taste cells versus Type III taste

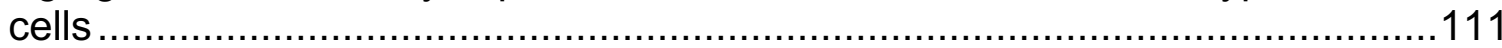

4.1. Proposed model of taste receptor cell desensitization ................................124

4.2. Secondary proposed model of purinergic receptor desensitization ..................126

4.3. RGS proteins to be pursued in future investigations .....................................129 


\section{Abbreviations}

$\begin{array}{ll}\text { A2B } & \text { Adenosine 2B receptor } \\ \text { ADP } & \text { Adenosine diphosphate } \\ \text { ANOVA } & \text { Analysis of variance } \\ \text { ATP } & \text { Adenosine triphosphate } \\ \text { CA } & \text { Citric acid } \\ \text { CAMP } & \text { Cyclic-adenosine monophosphate } \\ \text { CALHM1 } & \text { Calcium homeostasis modulator 1 } \\ \text { CDNA } & \text { Complimentary deoxyribonucleic acid } \\ \text { CNS } & \text { Central nervous system } \\ \text { CXCR4 } & \text { C-X-C chemokine receptor type 4 } \\ \text { CT } & \text { Chorda tympani } \\ \text { CV } & \text { Circumvallate Papilla } \\ \text { DAPI } & \text { 4',6-diamidino-2-phenylindole } \\ \text { DEP } & \text { Dishevelled/EGL-10/Pleckstrin homology domain } \\ \text { DNA } & \text { Deoxyribonucleic acid } \\ \text { EGTA } & \text { Ethylene glycol-bis( } \beta \text {-aminoethyl ether)-N,N,N',N'-tetraacetic acid } \\ \text { ENaC } & \text { Epithelial sodium channel } \\ \text { ERK1/2 } & \text { Extracellular related kinase 1/2 } \\ \text { GAP } & \text { GTPase activating protein } \\ \text { GDP } & \text { Guanosine diphosphate } \\ \text { GEF } & \text { Guanine nucleotide exchange factor } \\ \text { GLAST } & \text { Glutamate/aspartate transporter } \\ \text { GoLoco } & \text { G alpha i/o-loco } \\ \text { GPCR } & \text { G protein-coupled receptor } \\ \text { GRK } & \text { G protein-coupled receptor kinase } \\ \text { GTP } & \text { Guanosine triphosphate } \\ \text { Ga } & \text { Alpha subunit of the heterotrimeric G protein } \\ \text { GßY } & \text { Beta gamma subunits of the heterotrimeric G protein } \\ \text { GGL } & \text { G } \text {-like domain } \\ \text { H\&E } & \text { Hemotoxylin and Eosin } \\ \text { HCl } & \text { Hydrochloric acid } \\ \text { IHC } & \text { Immunohistochemistry } \\ \text { IMP } & \text { Inosine monophosphate } \\ \text { IP } & \text { Intraperitoneal } \\ \text { IP3 } & \text { Inositol 1,4,5-triphosphate } \\ \text { IP3R } & \text { Inositol 1,4,5-triphosphate receptor } \\ \text { ISH } & \text { In situ hybridization } \\ \text { JNK3 } & \text { C-Jun N-terminal kinase type 3 } \\ \text { KCI } & \text { Potassium Chloride } \\ \text { MAP } & \text { Mitogen activated protein } \\ \text { MEK } & \text { MAPK/extracellular signal-regulated kinase } \\ \text { mRNA } & \text { Messenger ribonucleic acid } \\ \text { MSG } & \text { Monosodium Glutamate } \\ \end{array}$




$\begin{array}{ll}\mathrm{NaCl} & \text { Sodium Chloride } \\ \mathrm{NCBI} & \text { National center for biotechnology information } \\ \mathrm{NH}_{4} \mathrm{Cl} & \text { Ammonium Chloride } \\ \text { NTPDase2 } & \text { Nucleoside triphosphate diphosphohydrolases-2 } \\ \text { OCT } & \text { Optimum cutting temperature } \\ \mathrm{P} 2 \mathrm{X} & \text { lonotropic purinergic receptor } \\ \mathrm{P} 2 Y & \text { Metabotropic purinergic receptor } \\ \text { PCR } & \text { Polymerase chain reaction } \\ \text { PDE } & \text { Phosphodiesterase } \\ \text { PDZ } & \text { PSD95/Dlg/ZO-1 homology domain } \\ \text { PKA } & \text { Protein kinase A (cAMP-dependent kinase) } \\ \text { PKC } & \text { Protein kinase C } \\ \text { PLC } & \text { Phospholipase C } \\ \text { qRT-PCR } & \text { Quantitative real-time polymerase chain reaction } \\ \text { R9AP } & \text { RGS9-1-anchor protein } \\ \text { RFP } & \text { Red fluorescent protein } \\ \text { RGS } & \text { Regulator of G protein signaling } \\ \text { RNA } & \text { Ribonucleic acid } \\ \text { ShRNA } & \text { Short hairpin ribonucleic acid } \\ \text { SNAP-25 } & \text { Synaptosomal-associated protein 25 } \\ \text { T1R } & \text { Type 1 taste receptor } \\ \text { T2R } & \text { Type 2 taste receptor } \\ \text { TBS-T } & \text { 0.3\% Tween 20 in Tris-buffered saline } \\ \text { TRPM5 } & \text { Transient receptor potential cation channel subfamily M member 5 } \\ \text { WHIM } & \text { Warts, hypogammaglobulinemia, immunodeficiency, and } \\ & \text { myelokathexis syndrome }\end{array}$




\section{Chapter 1}

General Introduction 


\section{1 - G Protein-Coupled Receptor Signaling}

\subsection{1 - Background}

An organism's survival is dependent on individual cells sensing and responding to a wide array of extracellular cues (e.g., neurotransmitters, hormones and chemokines, odorants, and tastants) (Rodbell, 1985; Gilman, 1987; Buck and Axel, 1991; Montmayeur et al., 2001). A cell's recognition of-and response to-membrane impermeable extracellular cues is dependent on cell surface receptors. The seventransmembrane proteins of the G protein-coupled receptor (GPCR) class make up a large proportion of cell surface receptors with the purpose of transducing extracellular cues into intracellular signals, which initiate a myriad of cellular responses.

Activation of GPCRs by extracellular signals conventionally generates messages within cells by interacting with heterotrimeric G protein complexes (Dohlman et al., 1987; Neer and Clapham, 1988). Heterotrimeric $G$ proteins are composed of single $\alpha, \beta$, and $\gamma$ subunits (Hepler and Gilman, 1992; Gudermann et al., 1996). When inactive, G $\alpha$ is bound to GDP and to $G \beta / \gamma$ subunits, that together associate with membrane-bound GPCRs. Ligand binding to a GPCR induces the receptor to undergo a conformational change (i.e., a reorientation of the 3-D arrangement of the seven transmembrane helices relative to one another), exposing intracellular portions of the receptor that allow it to function as a guanine nucleotide exchange factor (GEF) that reduces the affinity of GDP for the inactive G $\alpha$ subunit and allows for release of the nucleotide (Lambright et

al., 1994; Neer, 1995). Given the high concentration of GTP relative to GDP in cells and the affinity of $G \alpha$ subunits for GTP, GTP will bind to the $G \alpha$ subunit. The G $\alpha$ GTP 
subunit has reduced affinity for the $G \beta \gamma$ subunit, which leads to the dissociation of free G $\alpha \cdot G T P$ and $G \beta \gamma$ subunits (Lambright et al., 1996). Both the $G \alpha$ subunit and the $G \beta \gamma$ subunits, in their free state, activate downstream effector enzymes. Activated subunits have a number of different effectors, depending on the specific types of subunits involved (Freissmuth et al., 1989; Simon et al., 1991). Effectors of heterotrimeric G protein signaling include potassium and calcium ion channels, adenylyl cyclases, phosphodiesterases (PDEs), and various isoforms of phospholipase C (including PLC $\beta$ ), along with other effector proteins (Hamm, 1998; Marinissen and Gutkind, 2001; Offermanns, 2003; Goldsmith and Dhanasekaran, 2007). Free heterotrimeric G protein subunits will continue to influence effectors as long as the $\mathrm{G} \alpha$ subunit is bound to GTP. However, the $G \alpha$ subunit possesses internal GTPase activity, which catalyzes the hydrolysis of the bound GTP to GDP. The G $\alpha$ GDP subunit has greater affinity for the GBy subunits, causing the free subunits to return to a heterotrimeric $G$ protein complex and allow a restoration of interaction with a receptor. This activation/inactivation cycle allows heterotrimeric G-proteins to function as a molecular switch (Figure 1.1).

Figure 1.1. Guanine nucleotide cycle governing GPCR-mediated activation of heterotrimeric $\mathbf{G}$ protein signaling. Agonist (activator)-bound GPCRs stimulate signal onset by acting as guanine nucleotide exchange factors (GEFs) for $\mathrm{G} \alpha$ subunits, inducing GDP release, subsequent binding of GTP, and release of the $G \beta \gamma$ dimer. Both the free GTP-bound $G \alpha$ and free $G \beta \gamma$ subunits are then able to modulate the activity of various enzymes, ion

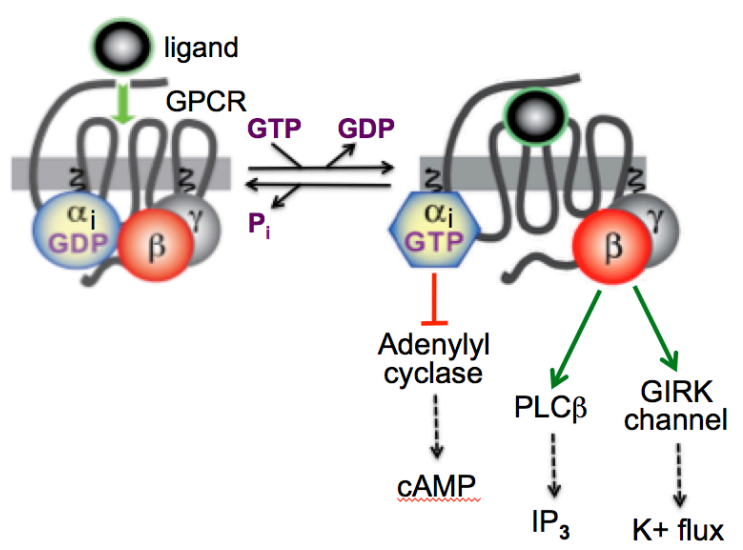
channels, and other effectors. 
Important molecular players in $G$ protein-mediated signaling are members of the Regulator of G protein signaling (RGS) proteins. In vitro, the GTP hydrolysis activity of purified $\mathrm{G} \alpha$ subunits is about 100-times slower than that observed in vivo (Vuong and Chabre, 1991; Angleson and Wensel, 1993). This timing paradox was resolved by the discovery of RGS proteins (Berman et al., 1996; Siderovski et al., 1996; Watson et al., 1996), which act as "breaks" on activated G protein signaling.

The following dissertation will focus on the two predominant forms of regulating G protein signaling pathways, with a particular focus on the role of these pathways in taste chemosensation and its regulation. Specifically, the role of one particular RGS protein limited in expression to tastant-receptive cells, Regulator of G protein Signaling21 (RGS21), will be investigated in GPCR-mediated taste responses, highlighting the importance of a rheostat mechanism to maintain the appropriate induction level and discontinuation of second messenger production in taste chemosensation.

\section{2 - Regulation of GPCRs}

\subsection{1a - Kinase-mediated regulation of GPCRs}

A number of regulatory mechanisms have been observed to prevent unrestrained signaling from GPCRs and to ultimately maintain the sensitivity of the G protein signal transduction system. That is, receptors can be phosphorylated by two types of kinases leading to the desensitization of a given receptor to its agonists (and a shift towards alternative signaling pathways) (Pierce and Lefkowitz, 2001). Canonically, kinases that are commonly activated downstream of heterotrimeric $G$ protein signaling, such as 
cAMP-dependent kinase (also referred to as protein kinase $A[P K A]$ ) and protein kinase C (PKC), can phosphorylate many different receptors and signaling components, reducing their responsiveness, regardless of agonist occupancy (Hoffman et al., 1994; Freedman and Lefkowitz, 1996). This process of unbiased desensitization of both active and inactive receptors is known as heterologous desensitization. However, other kinases play an important role in regulating $\mathrm{G}$ protein signaling.

GPCR kinases (GRKs) function similarly by phosphorylating receptors; however, these kinases only phosphorylate agonist-occupied receptors, allowing the specific desensitization of activated receptors, a process known as homologous desensitization (Lohse et al., 1990; Benovic et al., 1991; Lorenz et al., 1991; Pitcher et al., 1998). Canonically, following GRK-mediated phosphorylation of GPCRs, $\beta$-arrestin proteins can interact with GPCRs to block continued G protein activation and promote the internalization of the receptor into endosomes (Figure 1.2) (Von Zastrow and Kobilka, 1992; Ferguson et al., 1996; Lefkowitz, 1998). Internalization can either lead to dephosphorylation/resensitization of the receptor to allow recycling back to the cell membrane or degradation of the receptor in a process known as down-regulation (Oakley et al., 1999; Tsao and von Zastrow, 2000). 

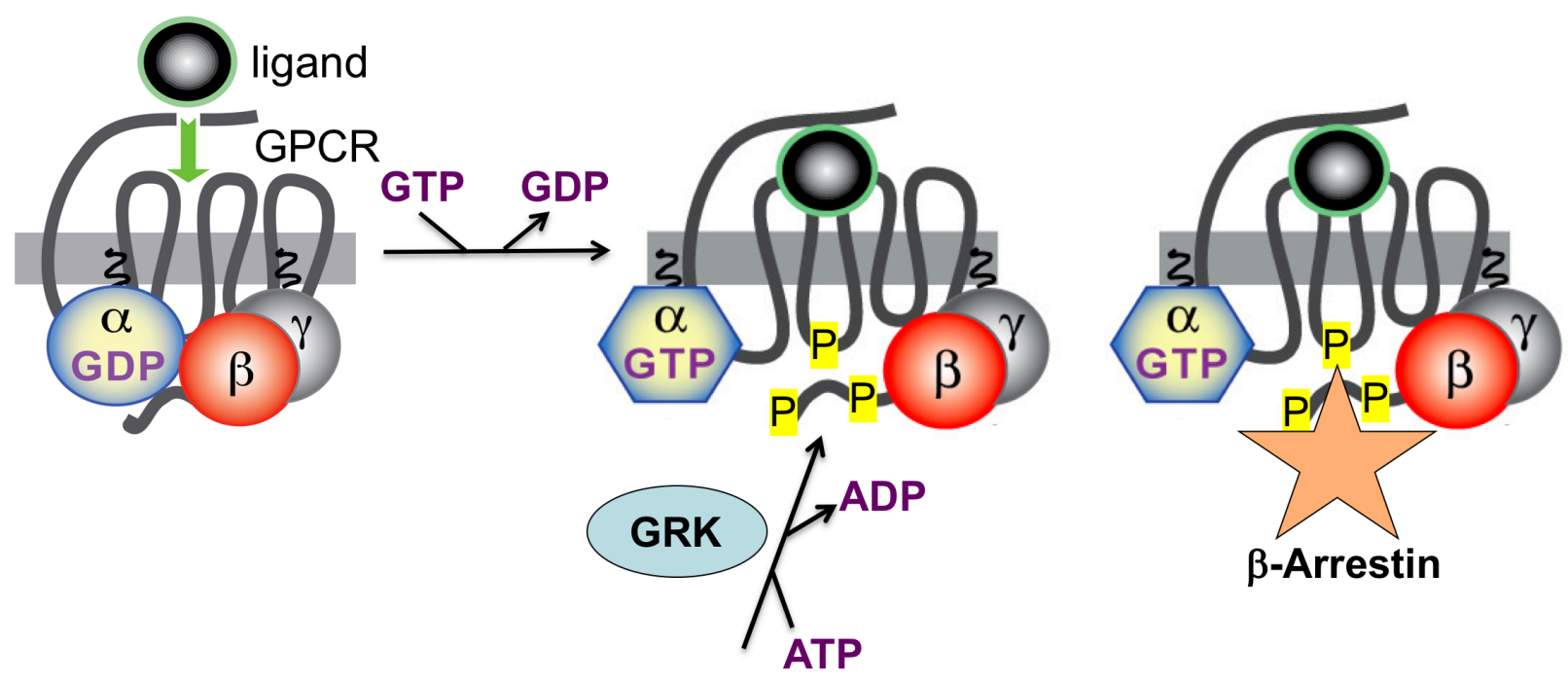

Figure 1.2. GRK-mediated desensitization. Activated GPCRs and their activated G $\beta \gamma$ subunits recruit GRKs (Inglese et al., 1992; Pitcher et al., 1992; Pack et al., 2018), which phosphorylate serine/threonine residues of agonist-bound receptors. $\beta$-arrestins bind to the phosphorylated residues to disrupt $G$ protein coupling and to adapt GPCRs to endocytosis machinery (Rajagopal and Shenoy, 2018). Endocytosis can lead to either dephosphorylation of the receptor and recycling back to the membrane or to degradation of the receptor in a process known as down-regulation (Oakley et al., 1999; Tsao and von Zastrow, 2000).

$\beta$-arrestin-mediated internalization not only functions to desensitize/resensitize agonist-bound GPCRs, but it also promotes the activation of different mitogen-activated protein (MAP) kinase-signaling pathways (Daaka et al., 1998; Luttrell et al., 1999). Following internalization of GPCRs into endosomes, $\beta$-arrestin proteins are able to link receptors to multiple MAP kinase signaling pathways. $\beta$-arrestin proteins are able to function as scaffolds for these signaling pathways (Luttrell et al., 1999; DeFea et al., 2000). First discovered in yeast, signaling scaffolds are proteins that can bring together sequential members of a signaling pathway to facilitate protein-protein interactions in distinct cellular locations allowing the targeting of this pathway to specific substrates (Choi et al., 1994; Marcus et al., 1994; Morrison and Davis, 2003). For example, $\beta$ arrestins can function as scaffolds for extracellular response kinase 1/2 (ERK1/2) and c- 
Jun N-terminal kinase type 3 (JNK3) signaling cascades (Luttrell et al., 1999, 2001; McDonald et al., 2000).

\subsection{1b. - Kinase-mediated regulation of GPCRs in physiology}

GPCR phosphorylation, $\beta$-arrestin-mediated receptor internalization, and MAP kinase pathway recruitment are critical in a number of physiological processes. Maintaining the appropriate induction level and discontinuation of second messenger production can be critical in preserving the sensitivity of signal transduction pathways to various ligands. For example, these kinase-mediated regulatory mechanisms are critical in maintaining normal taste chemosensation. Deletion of one of the main $\mathrm{G} \alpha$ proteins in taste receptor cells, G $\alpha$-gustducin (McLaughlin et al., 1992; Hoon et al., 1995; Wong et al., 1996), leads to reduced sensitivity to taste stimuli transduced by tastant-responsive GPCRs (Wong et al., 1996; Ming et al., 1999; Caicedo et al., 2003; Ruiz et al., 2003). Initially, it was thought that this lack of taste responsiveness in Ga-gustducin-deficient mice identified a key role for gustducin's regulation of PDE, which breaks down cAMP in the taste receptor cells, in the transduction of GPCR-mediated taste signals. However, the primacy of G $\beta \gamma$ subunit activation of PLC $\beta 2$ was subsequently reported (Huang et al., 1999; Zhang et al., 2003). Furthermore, in the absence of PLC $\beta 2$, or downstream signaling partners (e.g., IP3R, TRPM5, and CALHM1), responses to GPCR-mediated taste stimuli are completely lost (Zhang et al., 2003; Hisatsune et al., 2007; Taruno et al., 2013). Subsequent studies assessing the Ga-gustducin-deficient mouse revealed elevated tonic cAMP levels due to a reduction in basal PDE activity. This prolonged basal elevation in cAMP levels increases PKA activity, leading to the phosphorylation 
and desensitization of key membrane-bound taste signaling proteins (e.g., PLC $\beta 2$ and IP3R) (Clapp et al., 2008). Therefore, G $\alpha$-gustducin may regulate PKA-mediated heterologous desensitization, rather than serving a key role in the primary transduction of taste information from the periphery to the central nervous system (CNS). This example highlights the influence that heterologous desensitization can exert over active or inactive signaling pathways.

Homologous desensitization of GPCRs is also involved in numerous alternative physiological functions. Desensitization of agonist-occupied receptors can be critical to preventing excessive responses to stimuli. As stated above, GRKs initiate desensitization by phosphorylating agonist-activated receptors. For example, mutations in the C-terminal tail of the chemokine receptor CXCR4 and GRK3 have been found in patients with the autosomal dominant WHIM immunodeficiency syndrome (Hernandez et al., 2003; Balabanian et al., 2005, 2008). In this syndrome, patients have impaired CXCR4 desensitization and internalization, leading to prolonged G protein-dependent signaling, enhanced chemotaxis, and impaired leukocyte trafficking (Balabanian et al., 2008; Tarrant et al., 2013). This defect in homologous desensitization causes elevated G protein signaling, but ultimately results in a diminished immune system and leaves the patient with a markedly reduced neutrophil count.

GRK5, and potentially GRK2 and GRK6, are expressed in tastant-responsive lingual tissue (Premont et al., 1994; Zubare-Samuelov et al., 2005). However, only GRK5 has been found in all taste bud cells, including cells with tastant-responsive GPCRs (Zubare-Samuelov et al., 2005). Various amphipathic compounds that induce sweet and bitter tastes produce an aftertaste; a prolonged taste that does not dissipate 
quickly after the compound is removed from the mouth. It was found that these amphipathic compounds are capable of permeating taste cell membranes (Peri et al., 2000), which raised the possibility that their associated aftertaste may be the result of these tastants interfering with intracellular signaling (Naim et al., 1994). Subsequently, it was found that these tastants function as inhibitors of purified GRK2, GRK5, and PKA (Zubare-Samuelov et al., 2005), resulting in delayed GPCR desensitization and elevated signaling output in whole cells (Malach et al., 2015). Therefore, amphipathic tastants, such as non-caloric sweeteners and bitterants, may permeate taste bud cells and inhibit desensitization of taste receptors, thereby producing the prolonged taste response perceived as an aftertaste (Zubare-Samuelov et al., 2005). However, other compounds (i.e., non-amphipathic) that produce prolonged aftertaste likely impart this phenomenon via different mechanisms. Disruption of GRK-mediated desensitization by amphipathic tastants highlights the importance of desensitization of tastant-responsive GPCRs, which functions to prevent hyperactivity of taste receptor cells to tastants.

\subsection{2a - Regulators of G protein Signaling (RGS proteins)}

An additional mechanism to prevent unrestrained signaling from GPCRs and to maintain the sensitivity of heterotrimeric $G$ protein signal transduction involves direct modulation of the activation/inactivation cycle of the $G$ protein complexes. Regardless of receptor activity, the duration of heterotrimeric $G$ protein signaling is controlled by the length of time that the $\mathrm{G} \alpha$ subunit is bound to GTP. However, a discrepancy was observed between the slow rate of GTP hydrolysis of many purified $\mathrm{G} \alpha$ subunits in vitro and the rapid inactivation of their corresponding $\mathrm{G}$ protein signal transduction pathways 
in vivo. For example, a large discrepancy was observed in the slow off-rate of $\mathrm{G} \alpha$ transducin subunits in vitro versus the rapid inactivation of the phototransduction system in vivo (Vuong and Chabre, 1991; Angleson and Wensel, 1993). Purified Ga-transducin protein hydrolyzes GTP in vitro with a half-life of $\sim 15 \mathrm{sec}$, while the phototransduction system inactivates in $<1 \mathrm{sec}$ (Vuong and Chabre, 1991). G protein effectors (including $\operatorname{PLC} \beta$ ) were found to participate in regulation of the activation/inactivation cycle of $\mathrm{G} \alpha$ subunits by interacting with the GTP-bound $\alpha$-subunit and accelerating its GTPase activity; as such, these effectors were also described as GTPase Activating Proteins (GAPs) of heterotrimeric G proteins (Arshavsky and Bownds, 1992; Berstein et al., 1992; Kozasa et al., 1998; Scholich et al., 1999). However, the GAP function of these effectors alone could not account for the discrepancy in slow GTPase activity of many $\mathrm{G} \alpha$ subunits when purified in vitro versus the rapid inactivation of their corresponding $\mathrm{G}$ protein signal transduction pathways in vivo. This timing paradox was fully resolved upon discovery of the family of Regulator of G protein Signaling (RGS) proteins (Druey et al., 1996; Koelle and Horvitz, 1996; Siderovski et al., 1996). RGS proteins were initially discovered in a number of different species, including the yeast Saccharomyces cerevisiae (Chan and Otte, 1982a, 1982b; Dohlman et al., 1996), the aspergillus Emericella nidulans (Yu et al., 1996), the nematode Caenorhabiditis elegans (Koelle and Horvitz, 1996), and the human Homo sapiens (Druey et al., 1996; Siderovski et al., 1996). RGS homologs have now been identified in plants, even in the absence of seven-transmembrane GPCRs that function as GEFs, suggesting the evolutionary precedence of GAPs in regulating heterotrimeric G proteins (Chen et al., 2003b; Choudhury et al., 2012). This evolutionary conservancy points to the critical role of the 
RGS protein family in maintaining proper responsiveness of cells to ultimately promote their survival.

Members of the mammalian RGS protein family contain a conserved $\sim 120$ amino-acid motif, known as an "RGS-box" or RGS domain. This region can interact with $\mathrm{G} \alpha \cdot$ GTP subunits to function as an enzyme to catalyze the hydrolysis of GTP to GDP (Berman et al., 1996; Hunt et al., 1996; Watson et al., 1996). The GAP activity exerted by the RGS family of proteins functions to dramatically accelerate the termination of heterotrimeric $G$ protein activity and thus the downstream signaling activity. Since the initial discovery of the RGS family of proteins, 37 members have been identified in the human genome (Siderovski and Willard, 2005).

\subsection{2b - RGS proteins in physiology}

Not only have RGS proteins been identified in the human genome, but also numerous physiological roles have been identified. As referenced above, the $\mathrm{G} \alpha$ protein found in the retinal photoreceptor cells, G $\alpha$-transducin, hydrolyzes GTP in vitro much slower than cells are able to recover following light stimulation in vivo (Vuong and Chabre, 1991; Angleson and Wensel, 1993), suggesting a likely regulatory mechanism increasing GTPase activity to inactivate this system. The specific protein functioning as a GAP on transducin in retinal photoreceptors is RGS9 (Cowan et al., 1998; He et al., 1998; Makino et al., 1999). RGS9 requires an obligate partner, $G \beta 5$, to remain stable (Chen et al., 2003a). Additionally, RGS9 binds a transmembrane protein, R9AP, to tether the RGS9.G $\beta 5$ complex to the outer segment of the photoreceptor (Hu and Wensel, 2002). Experimental studies in mice with genetic deletion of any of these three 
proteins revealed nearly identical defective photoresponses, with a greatly reduced recovery following light stimulation (Chen et al., 2000; Hu and Wensel, 2002; Krispel et al., 2003; Keresztes et al., 2004). Additionally, mutations to RGS9 and R9AP have been found in humans with defects in the off-rate of the phototransduction system, resulting in normal visual acuity, but a severely reduced ability to see moving objects (Nishiguchi et al., 2004).

The majority of RGS proteins contain multiple functional domains, in addition to the RGS box that conveys GAP activity. For example, the GRKs, which were discussed above as kinases that phosphorylate GPCRs, also have an RGS box (Siderovski et al., 1996) giving them the dual ability to directly regulate both heterotrimeric $G$ proteins and receptors (Carman et al., 1999). An additional role for these supplementary domains is to target RGS proteins to specific subcellular regions and receptors. RGS9 proteins contain a DEP (Dishevelled/EGL-10/Pleckstrin homology) domain, which functions to tether them to R9AP proteins in the outer segment of the photoreceptor (Martemyanov et al., 2003). RGS proteins are organized into eight subfamilies based on sequence homology and the presence of specific functional domains (Figure 1.3). For example, the GRKs make up a subfamily of RGS proteins known as the GRK or G subfamily. RGS9 is a member of the R7 or C subfamily, which contain a G $\gamma$-like (GGL) domain, the domain causing these proteins to form obligate heterodimers with $G \beta 5$ (Chen et al., 2003a). Most members of the R12 or D subfamily contain complex domain architectures. Specifically, RGS12 and RGS14 contain tandem Ras-binding domains, in addition to a GoLoco motif, which prevents GDP dissociation from Gai/o subunits (Siderovski et al., 1999; Kimple et al., 2001; Siderovski and Willard, 2005). RGS12 also 
has PDZ (PSD95/DIg/ZO-1 homology) and phosphotyrosine-binding domains (Schiff et al., 2000), which cause RGS12 to interact with and regulate specific receptors (Willard et al., 2007). Ultimately, the domain architecture of these two R12 subfamily members can bring together components of the Ras.GTP/Raf/MEK/ERK signaling pathway to promote sustained ERK activity (Willard et al., 2007, 2009; Shu et al., 2010). The subfamily of RGS proteins with the least complex domain architecture, which are little more than an isolated RGS box consisting of a nine-helical bundle, are called the R4 or B subfamily. Members of this family include RGS1-5, 8, 13, 16, 18, and 21 (Woodard et al., 2015). Since R4 subfamily members do not have extensive functional domains beyond an RGS box, they often have less specificity for receptors and are more likely to have function restricted by selective expression patterns. 


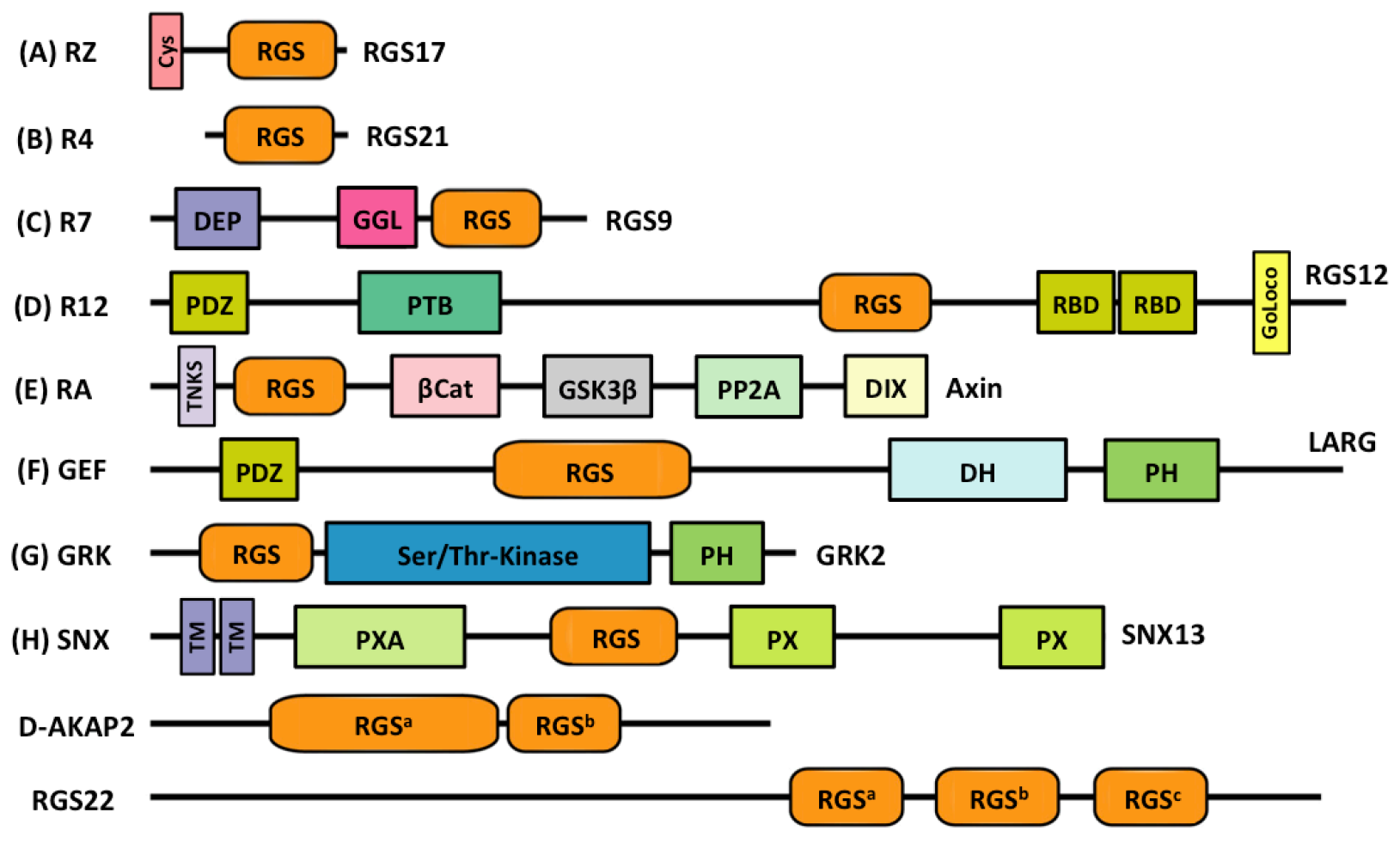

Figure 1.3. Representative members of the mammalian RGS protein subfamilies. Two nomenclatures are alternatively used for several RGS protein subfamilies. A/RZ subfamily members, such as RGS17 (Mao et al., 2004), are characterized by an Nterminal poly-cysteine region ("Cys") that can be palmitoylated (Jones, 2004). Members of the B/R4 subfamily (RGS21), C/R7 subfamily (RGS9), D/R12 subfamily (RGS12), and G/GRK subfamily (GRK2) are described in the text. Members of the E/RA subfamily, Axin and Axil, are negative regulators of the Wnt signaling pathway; neither protein has been shown to interact with Ga subunits, but rather their RGS box interacts with the tumor suppressor protein adenomatous polyposis coli (APC) (Spink et al., 2000). Axin and Axil also contain other domains that interact with tankyrase (TNKS), $\beta$ catenin ( $\beta$ Cat), the kinase GSK3 $\beta$, the phosphatase PP2A, and the protein Dishevelled (DIX) (Kikuchi, 1999). The F/GEF subfamily, such as leukemia-associated RhoGEF (LARG), includes RhoA-specific guanine nucleotide exchange factors (GEFs) with canonical Dbl-homology $(\mathrm{DH})$ and pleckstrin-homology $(\mathrm{PH})$ domains (Jaiswal et al., 2011). Three sorting nexins (SNX13, SNX14, SNX25) comprise the H/SNX subfamily of RGS proteins, having RGS boxes between phosphatidylinositol-binding (PX) and PXassociated (PXA) domains with putative transmembrane regions (TM) allowing association with endosomes. The multiple RGS-box family members D-AKAP2 and RGS22 fall outside the eight established subfamilies. 


\subsection{1 - Taste Physiology}

Pleasant and aversive taste stimuli are capable of being distinguished even in newborn human infants (Ganchrow et al., 1983). The mammalian taste system detects substances via taste buds, the sensory end organs of gustation in the fungiform papillae of the anterior tongue (Arvidson, 1979), in the foliate and circumvallate papillae of the posterior tongue (Guth, 1958; Murray and Murray, 1967), and in the posterior soft palate (Nilsson, 1979). These taste buds are finely tuned to detect a variety of compounds to ultimately regulate intake of nutrients, spoiled foods, and toxic substances. Taste buds are made up of a cluster of roughly 50-100 sensory cells (Roper and Chaudhari, 2017). Conventionally, taste bud cells are divided into three different types of sensory cells: Type I, II, and III taste cells (Finger, 2005). These cell types were initially based on staining and morphological characteristics (Murray, 1993; Pumplin et al., 1997; Yee et al., 2001); however, these staining and morphological characteristics also correlate with the specific functional roles of these taste cells. Type I taste cells are known as glial-like support cells, as they have similarities in expression profile and function with glial cells of the nervous system (Pumplin et al., 1997; Lawton et al., 2000; Bartel et al., 2006). These Type I cells express the glial glutamate/aspartate transporter (GLAST), which is responsible for re-uptake of glutamate in the nervous system (Lawton et al., 2000). To maintain the extracellular milieu of ATP, Type I cells also express an ecto-ATPase known as nucleoside triphosphate diphosphohydrolases-2 (NTPDase2) (Bartel et al., 2006; Vandenbeuch et al., 2013). Type II taste cells are commonly referred to as "taste receptor cells", as these cells contain the tastant-responsive GPCRs and downstream signaling components known to mediate sweet, bitter, and umami taste modalities 
(Clapp et al., 2001, 2004; Miyoshi et al., 2001). However, Type II taste receptor cells lack voltage-gated calcium channels and the target SNARE protein SNAP-25 (Clapp et al., 2006), characteristics typically necessary for synaptic transmission at conventional synapses (Yang et al., 2000). Type III taste cells are referred to as pre-synaptic taste cells as they are the only taste bud cells that express SNAP-25 and voltage-gated calcium channels (Yang et al., 2000; Yee et al., 2001; Clapp et al., 2004, 2006), allowing a conventional synapse with afferent gustatory nerves (Kinnamon et al., 1988; Royer and Kinnamon, 1991; Chaudhari and Roper, 2010).

Five basic sensory qualities are detected by the gustatory system: sweet, bitter, umami ("savory"), sour, and salty. Three of these taste qualities are detected by GPCRs on Type II taste receptor cells. Sweet and umami tastes are mediated by type 1 taste receptor (T1R) GPCRs (Montmayeur et al., 2001; Nelson et al., 2001, 2002; Li et al., 2002; Zhao et al., 2003), while bitter tastes are detected by a family of $\sim 30$ GPCRs, the type 2 taste receptors (T2Rs), most of which are expressed in the same subset of taste receptor cells (Hoon et al., 1999; Adler et al., 2000; Chandrashekar et al., 2000; Bufe et al., 2002). Unlike the T2Rs, which are active as monomers (Meyerhof, 2005; Mueller et al., 2005), the T1Rs are only functional as heterodimers (Li et al., 2002; Nelson et al., 2002). L-glutamate and 5'-ribonucleotides (umami compounds) signal through the T1R1-T1R3 heterodimer (Nelson et al., 2002), while sweeteners activate T1R2-T1R3 heterodimers to initiate signaling ( $\mathrm{Li}$ et al., 2002). Sour taste responses are not mediated by GPCR signaling in Type II cells; rather, they are mediated by entry of protons through a $\mathrm{Zn}^{2+}$-sensitive proton channel recently identified as OTOP1 in Type III 
taste cells (Chang et al., 2010; Tu et al., 2018). These intracellular protons subsequently block the inwardly rectifying $\mathrm{K}^{+}$channel KIR2.1 (Ye et al., 2016).

Transduction mechanisms mediating salty taste are the least understood of the five basic taste qualities. The prototypical inducer of salty taste is $\mathrm{NaCl}$; however, $\mathrm{NaCl}$ can also elicit some sweet, bitter, and sour taste in dilute concentrations (Bartoshuk et al., 1978). The taste confusion associated with $\mathrm{NaCl}$ taste adds complexity to the traditional view of the chemosensory field, as each of the basic taste qualities are thought to have unique mechanisms for their sensory reception. Various groups studying salt taste have come to differing conclusions that the cation, the anion, and the water of hydration of $\mathrm{NaCl}$ may all contribute to gustation (Beidler, 1953; Bartoshuk et al., 1964; Lewandowski et al., 2016). An additional source of perplexity arises from the multiple pathways involved in sensory reception of salts (Roper, 2015). These diverse pathways appear to be concentration-specific, as low concentrations of salts can induce appetitive responses, whereas high concentrations of salts elicit aversive responses. The most well-established pathway mediating salt taste is the amiloride-sensitive pathway (Heck et al., 1984; DeSimone and Ferrell, 1985). Amiloride is thought to block epithelial sodium channels (ENaCs) in a dedicated population of taste cells, which are possibly Type I taste cells, but this has yet to be unambiguously confirmed (Vandenbeuch et al., 2008; Chandrashekar et al., 2010; Roper, 2015). However, amiloride is unable to fully block salty taste, especially at high salt concentrations. To account for this amiloride-insensitive salt taste, high salt concentrations have been proposed to co-opt sour- and bitter-responsive cells to stimulate aversive pathways (Oka et al., 2013; Lewandowski et al., 2016), implicating G protein signaling within Type 
II cells in the aversive response to high salt concentrations (Oka et al., 2013). Additionally, recent work in transgenic mice lacking various components of GPCRmediated taste signaling has generated speculation that Type II cells may also be involved in appetitive responses to moderate concentrations of $\mathrm{NaCl}$ (Damak et al., 2006; Hisatsune et al., 2007; Tordoff et al., 2014); however, these finding have been inconsistent (Wong et al., 1996; Zhang et al., 2003). The mechanism(s) whereby moderate concentrations of $\mathrm{NaCl}$ may activate Type II taste cells is not yet clear, but $\mathrm{NaCl}$ may activate a receptor sensitive to $\mathrm{Na}^{+}$on Type II cells or these cells may become active via communication from other $\mathrm{Na}^{+}$-responsive cell types (e.g., $\mathrm{ENaC}+$ taste cells) (Tordoff et al., 2014).

Downstream signaling by taste GPCRs is thought to be mediated predominantly by PLCß2 and, subsequently, the TRPM5 channel (Zhang et al., 2003), leading ultimately to ATP release (Bo et al., 1999; Finger et al., 2005; Murata et al., 2010). Activation of PLCB2 by T2R bitter taste receptors is mediated by a heterotrimeric $\mathrm{G}$ protein complex containing a $\mathrm{G} \alpha$ subunit ( $\mathrm{G} \alpha$-gustducin or a related $\mathrm{G} \alpha$ subfamily member), Gß3, and Gy13 (McLaughlin et al., 1992; Wong et al., 1996; Ming et al., 1998; Huang et al., 1999; Kusakabe et al., 2000; Shindo et al., 2008). GPCR-mediated tastant signaling is primarily transduced by $G \alpha$ nucleotide exchange and release of the $G \beta Y$ dimer, which in turn activates PLC $\beta 2$ to produce inositol 1,4,5-triphosphate $\left(\mathrm{IP}_{3}\right)(\mathrm{Hwang}$ et al., 1990; Huang et al., 1999). $\mathrm{IP}_{3}$ causes calcium release from the endoplasmic reticulum (Akabas et al., 1988) and, subsequently, activation of the TRPM5 channel (Zhang et al., 2003). Opening of TRPM5 channels triggers membrane depolarization and extracellular release of ATP through the calcium homeostasis modulator-1 
(CALHM1) ion channel (Finger et al., 2005; Taruno et al., 2013), which in turn activates ATP-gated, ionotropic purinergic receptors (P2X2 and $\mathrm{P} 2 \mathrm{X} 3$ ) on gustatory afferent nerve fibers (Bo et al., 1999; Finger et al., 2005; Eddy et al., 2009; Kinnamon and Finger, 2013; Vandenbeuch et al., 2015). ATP also functions as an autocrine factor to further augment ATP release from Type II cells (Kinnamon and Finger, 2013). Specifically, ATP activates metabotropic purinergic GPCRs (P2YRs) on Type II taste cells themselves (Kataoka et al., 2004; Bystrova et al., 2006; Huang et al., 2009), acting to potentiate ATP release. Extracellular ATP in the taste bud is also degraded by NTPDase2 to adenosine (Vandenbeuch et al., 2013), which activates the A2B receptor on Type II taste receptor cells to enhance ATP release in response to sweet taste stimuli (Dando et al., 2012; Kataoka et al., 2012).

In Type II taste cell signaling, as in other GPCR signaling cascades, G $\beta \gamma$ activity is terminated when the intrinsic GTPase activity of G $\alpha$ hydrolyzes GTP to GDP, causing G $\beta \gamma$ re-association and restoration of the heterotrimeric complex (Hoon et al., 1995; Siderovski and Willard, 2005). Ga-gustducin, the most extensively characterized $\mathrm{G} \alpha$ in the taste system, is closely related to the $G \alpha$-transducins ( $G \alpha_{t(\text { rod })}$ and $\left.G \alpha_{t(\text { cone })}\right)$ of rod and cone photoreceptors (McLaughlin et al., 1992). All three of these $\mathrm{G} \alpha$ subunits have similar intrinsic GTPase activity, which determines the lifetime of a $G \alpha$ subunit in its GTP-bound (active) form and, thus, the duration of G $\alpha$-dependent signal transduction. For $\mathrm{G} \alpha$-transducin subunits, as stated above, the large discrepancy in slow GTPase activity in vitro and the rapid inactivation of phototransduction in vivo (Vuong and Chabre, 1991; Angleson and Wensel, 1993) was resolved with the discovery of RGS proteins (Druey et al., 1996; Siderovski et al., 1996; Watson et al., 1996), specifically 
RGS9 (Cowan et al., 1998; He et al., 1998; Makino et al., 1999). Thus, it is very likely that tastant signal transduction, which involves $G \alpha$-gustducin and other $G \alpha$ subunits, is similarly regulated by an RGS protein.

\subsection{2 - Regulator of G Protein Signaling-21 (RGS21) in taste physiology}

The smallest and most recently identified member of the R4 subfamily of RGS proteins is RGS21 (von Buchholtz et al., 2004). RGS21 is only 152 amino acids, with $\sim 120$ amino acids accounting for the established RGS box and probably conferring GAP activity without receptor specificity (von Buchholtz et al., 2004; Li et al., 2005). In 2004, von Buchholtz et al. identified Rgs21 from isolated rat foliate and fungiform papillae (von Buchholtz et al., 2004), which are small projections in the oral cavity containing taste buds, and reported that Rgs21 expression is restricted to taste tissue - specifically, a subpopulation of taste cells within all types of taste buds (foliate, fungiform, circumvallate, and palate) (von Buchholtz et al., 2004). Double-label in situ hybridization revealed that Rgs21 is co-expressed with transcript of tastant-responsive GPCRs and that virtually all cells expressing Rgs 21 co-expressed Plc $\beta 2$, a key component of GPCR-mediated taste signaling. Shortly after the initial identification of RGS21, the mRNA transcript was found to be ubiquitously present in all human tissues tested ( $\mathrm{Li}$ et al., 2005). To reconcile these findings in rats and humans, differential roles for RGS21 was suggested in different species (Woodard et al., 2015). However, re-analysis of human tissue, subsequent to the original analysis by Li and colleagues ( $\mathrm{Li}$ et al., 2005), found RGS21 transcript expression to be restricted to tastant-responsive tissue (Cohen et al., 2012; Kimple et al., 2014). Additionally, the Siderovski lab created Rgs21::RFP 
transgenic mouse and surveyed RFP expression in various tissues, including tongue, trachea, lung, intestine, and liver, using immunohistochemistry (Cohen et al., 2012; Kimple et al., 2014). RFP detection revealed robust Rgs21 promoter activity in taste cells of the circumvallate papillae; consistent with the report of von Buchholtz and colleagues, no other tissue from the Rgs21::RFP transgenic mouse displayed detectable levels of RFP immunoreactivity (von Buchholtz et al., 2004; Cohen et al., 2012; Kimple et al., 2014). In addition to being expressed in gustatory tissue, RGS21 is also found to be present in tissues with extra-oral taste receptors, such as the sinonasal mucosa (Kimple et al., 2014).

Biochemical analyses have confirmed that purified RGS21 protein acts as a promiscuous GAP for multiple different $\mathrm{G} \alpha$ subunits of the Gai/o and $\mathrm{G} \alpha q$ subfamilies, including $\mathrm{G} \alpha$-gustducin and others involved in tastant signal transduction (Cohen et al., 2012; Kimple et al., 2014). Measuring the separate effects of RGS21 overexpression and shRNA-mediated knockdown in the tastant-responsive, immortalized human bronchial epithelial cell line 16HBE (i.e., a cell line that natively expresses bitterreceptive T2Rs and the necessary downstream signaling components) confirmed that RGS21 acts, at least in cell culture, to oppose bitter signaling to calcium second messenger changes (Cohen et al., 2012), consistent with its demonstrable $\mathrm{G} \alpha$-directed GAP activity in vitro (Figure 1.4). The following dissertation was therefore developed to address the idea of RGS21 as a potential taste reception-specific regulator in vivo. 


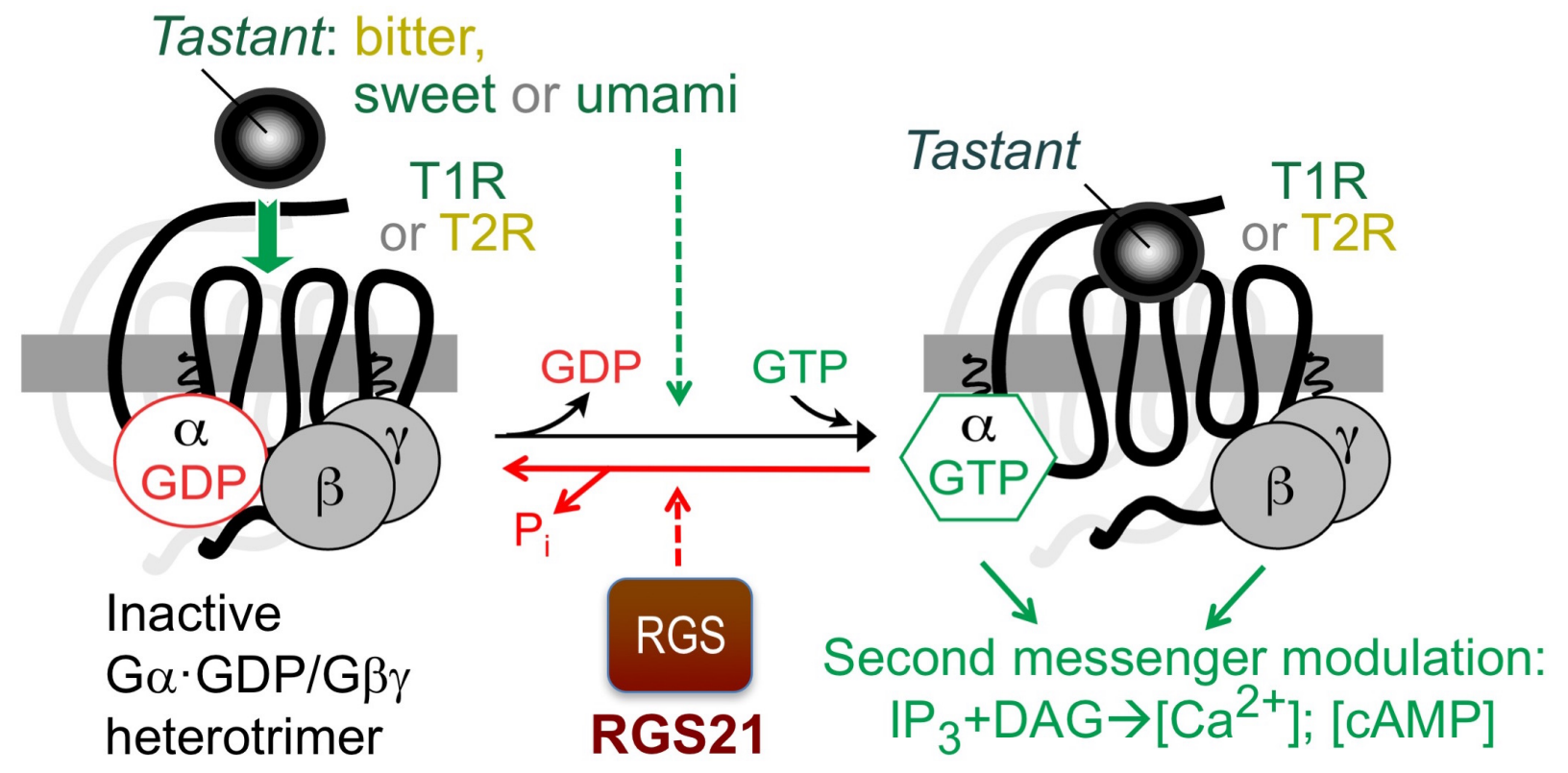

Figure 1.4. Simplified model of the Ga.GDP/Ga.GTP cycle controlled by tastantresponsive GPCRs.

The $G \beta \gamma$ heterodimer serves to couple $G \alpha$ to the receptor and to prevent spontaneous GDP dissociation. Tastant binding to the taste receptor stimulates signal onset by acting as a guanine nucleotide exchange factor (GEF) for $G \alpha$ subunits, stimulating GDP release, subsequent binding of GTP, and release of the G $\beta \gamma$ dimer. Both $G \alpha$ and $G \beta \gamma$ are then free to interact with effectors, such as phosphodiesterase and PLC $\beta 2$, thereby modulating the levels of second messengers as indicated. Regulator of $G$ protein Signaling (RGS) proteins, like RGS21, are known to stimulate signal termination by acting as GTPase-accelerating proteins (GAPs) for Ga subunits (Druey et al., 1996; Siderovski et al., 1996; Watson et al., 1996). Prior work suggests that RGS21 acts in this $\mathrm{G} \alpha \cdot \mathrm{GDP} / \mathrm{G} \alpha \cdot \mathrm{GTP}$ cycle in opposition to activated T2R bitterant receptors, at least in vitro in tastant-responsive human epithelial cells (Cohen et al., 2012). 


\section{4 - References}

Adler E, Hoon MA, Mueller KL, Chandrashekar J, Ryba NJ, Zuker CS (2000) A novel family of mammalian taste receptors. Cell 100:693-702.

Akabas MH, Dodd J, Al-Awqati Q (1988) A bitter substance induces a rise in intracellular calcium in a subpopulation of rat taste cells. Science 242:1047-1050.

Angleson JK, Wensel TG (1993) A GTPase-accelerating factor for transducin, distinct from its effector cGMP phosphodiesterase, in rod outer segment membranes. Neuron 11:939-949.

Arshavsky VY, Bownds MD (1992) Regulation of deactivation of photoreceptor G protein by its target enzyme and cGMP. Nature 357:416-417.

Arvidson K (1979) Location and variation in number of taste buds in human fungiform papillae. Scand J Dent Res 87:435-442.

Balabanian K, Lagane B, Pablos JL, Laurent L, Planchenault T, Verola O, Lebbe C, Kerob D, Dupuy A, Hermine O, Nicolas J-F, Latger-Cannard V, Bensoussan D, Bordigoni P, Baleux F, Le Deist F, Virelizier J-L, Arenzana-Seisdedos F, Bachelerie F (2005) WHIM syndromes with different genetic anomalies are accounted for by impaired CXCR4 desensitization to CXCL12. Blood 105:2449-2457.

Balabanian K, Levoye A, Klemm L, Lagane B, Hermine O, Harriague J, Baleux F, Arenzana-Seisdedos F, Bachelerie F (2008) Leukocyte analysis from WHIM syndrome patients reveals a pivotal role for GRK3 in CXCR4 signaling. J Clin Invest 118:1074-1084.

Bartel DL, Sullivan SL, Lavoie ÉG, Sévigny J, Finger TE (2006) Nucleoside triphosphate 
diphosphohydrolase-2 is the ecto-ATPase of type I cells in taste buds. J Comp Neurol 497:1-12.

Bartoshuk LM, McBurney DH, Pfaffmann C (1964) Taste of sodium chloride solutions after adaptation to sodium chloride: implications for the "water taste". Science 143:967-968.

Bartoshuk LM, Murphy C, Cleveland CT (1978) Sweet taste of dilute $\mathrm{NaCl}$ :

Psychophysical evidence for a sweet stimulus. Physiol Behav 21:609-613.

Beidler LM (1953) Properties of chemoreceptors of tongue of rat. J Neurophysiol 16:595-607.

Benovic JL, Onorato JJ, Arriza JL, Stone WC, Lohse M, Jenkins NA, Gilbert DJ, Copeland NG, Caron MG, Lefkowitz RJ (1991) Cloning, expression, and chromosomal localization of beta-adrenergic receptor kinase 2. A new member of the receptor kinase family. J Biol Chem 266:14939-14946.

Berman DM, Wilkie TM, Gilman AG (1996) GAIP and RGS4 Are GTPase-Activating Proteins for the Gi Subfamily of G Protein a Subunits. Cell 86:445-452.

Berstein G, Blank JL, Jhon DY, Exton JH, Rhee SG, Ross EM (1992) Phospholipase Cbeta 1 is a GTPase-activating protein for $\mathrm{Gq} / 11$, its physiologic regulator. Cell $70: 411-418$.

Bo X, Alavi A, Xiang Z, Oglesby I, Ford A, Burnstock G (1999) Localization of ATPgated $\mathrm{P} 2 \mathrm{X} 2$ and $\mathrm{P} 2 \mathrm{X} 3$ receptor immunoreactive nerves in rat taste buds. Neuroreport 10:1107-1111.

Buck L, Axel R (1991) A novel multigene family may encode odorant receptors: A molecular basis for odor recognition. Cell 65:175-187. 
Bufe B, Hofmann T, Krautwurst D, Raguse J-D, Meyerhof W (2002) The human TAS2R16 receptor mediates bitter taste in response to $\beta$-glucopyranosides. Nat Genet 32:397-401.

Bystrova MF, Yatzenko YE, Fedorov I V., Rogachevskaja OA, Kolesnikov SS (2006) P2Y isoforms operative in mouse taste cells. Cell Tissue Res 323:377-382.

Caicedo A, Pereira E, Margolskee RF, Roper SD (2003) Role of the G-protein subunit alpha-gustducin in taste cell responses to bitter stimuli. J Neurosci 23:9947-9952.

Carman C V, Parent JL, Day PW, Pronin AN, Sternweis PM, Wedegaertner PB, Gilman AG, Benovic JL, Kozasa T (1999) Selective regulation of Galpha(q/11) by an RGS domain in the G protein-coupled receptor kinase, GRK2. J Biol Chem 274:3448334492.

Chan RK, Otte CA (1982a) Isolation and genetic analysis of Saccharomyces cerevisiae mutants supersensitive to $\mathrm{G} 1$ arrest by a factor and alpha factor pheromones. Mol Cell Biol 2:11-20.

Chan RK, Otte CA (1982b) Physiological characterization of Saccharomyces cerevisiae mutants supersensitive to $\mathrm{G} 1$ arrest by a factor and alpha factor pheromones. Mol Cell Biol 2:21-29.

Chandrashekar J, Kuhn C, Oka Y, Yarmolinsky DA, Hummler E, Ryba NJP, Zuker CS (2010) The cells and peripheral representation of sodium taste in mice. Nature 464:297-301.

Chandrashekar J, Mueller KL, Hoon MA, Adler E, Feng L, Guo W, Zuker CS, Ryba NJP (2000) T2Rs Function as Bitter Taste Receptors. Cell 100:703-711.

Chang RB, Waters H, Liman ER (2010) A proton current drives action potentials in 
genetically identified sour taste cells. Proc Natl Acad Sci 107:22320-22325.

Chaudhari N, Roper SD (2010) The cell biology of taste. J Cell Biol 190:285-296.

Chen C-K, Burns ME, He W, Wensel TG, Baylor DA, Simon MI (2000) Slowed recovery of rod photoresponse in mice lacking the GTPase accelerating protein RGS9-1. Nature 403:557-560.

Chen CK, Eversole-Cire P, Zhang H, Mancino V, Chen YJ, He W, Wensel TG, Simon MI (2003a) Instability of GGL domain-containing RGS proteins in mice lacking the G protein -subunit G 5. Proc Natl Acad Sci 100:6604-6609.

Chen J-G, Willard FS, Huang J, Liang J, Chasse SA, Jones AM, Siderovski DP (2003b) A Seven-Transmembrane RGS Protein That Modulates Plant Cell Proliferation. Science 301:1728-1731.

Choi KY, Satterberg B, Lyons DM, Elion EA (1994) Ste5 tethers multiple protein kinases in the MAP kinase cascade required for mating in S. cerevisiae. Cell 78:499-512. Choudhury SR, Westfall CS, Laborde JP, Bisht NC, Jez JM, Pandey S (2012) Two Chimeric Regulators of G-protein Signaling (RGS) Proteins Differentially Modulate Soybean Heterotrimeric G-protein Cycle. J Biol Chem 287:17870-17881.

Clapp TR, Medler KF, Damak S, Margolskee RF, Kinnamon SC (2006) Mouse taste cells with $\mathrm{G}$ protein-coupled taste receptors lack voltage-gated calcium channels and SNAP-25. BMC Biol 4:1-9.

Clapp TR, Stone LM, Margolskee RF, Kinnamon SC (2001) Immunocytochemical evidence for co-expression of Type III IP3 receptor with signaling components of bitter taste transduction. BMC Neurosci 2:6.

Clapp TR, Trubey KR, Vandenbeuch A, Stone LM, Margolskee RF, Chaudhari N, 
Kinnamon SC (2008) Tonic activity of Ga-gustducin regulates taste cell responsivity. FEBS Lett 582:3783-3787.

Clapp TR, Yang R, Stoick CL, Kinnamon SC, Kinnamon JC (2004) Morphologic characterization of rat taste receptor cells that express components of the phospholipase C signaling pathway. J Comp Neurol 468:311-321.

Cohen SP, Buckley BK, Kosloff M, Garland AL, Bosch DE, Cheng G, Radhakrishna H, Brown MD, Willard FS, Arshavsky VY, Tarran R, Siderovski DP, Kimple AJ (2012) Regulator of G-protein signaling-21 (RGS21) is an inhibitor of bitter gustatory signaling found in lingual and airway epithelia. J Biol Chem 287:41706-41719.

Cowan CW, Fariss RN, Sokal I, Palczewski K, Wensel TG (1998) High expression levels in cones of RGS9, the predominant GTPase accelerating protein of rods. Proc Natl Acad Sci 95:5351-5356.

Daaka Y, Luttrell LM, Ahn S, Della Rocca GJ, Ferguson SS, Caron MG, Lefkowitz RJ (1998) Essential role for G protein-coupled receptor endocytosis in the activation of mitogen-activated protein kinase. J Biol Chem 273:685-688.

Damak S, Rong M, Yasumatsu K, Kokrashvili Z, Pérez CA, Shigemura N, Yoshida R, Mosinger B, Glendinning JI, Ninomiya Y, Margolskee RF (2006) Trpm5 null mice respond to bitter, sweet, and umami compounds. Chem Senses 31:253-264.

Dando R, Dvoryanchikov G, Pereira E, Chaudhari N, Roper SD (2012) Adenosine enhances sweet taste through A2B receptors in the taste bud. J Neurosci 32:322330.

DeFea KA, Zalevsky J, Thoma MS, Dery O, Mullins RD, Bunnett NW (2000) $\beta$-Arrestindependent Endocytosis of Proteinase-activated Receptor2 is Required for 
Intracellular Targeting of Activated ERK1/2. J Cell Biol 148:1267-1281.

DeSimone JA, Ferrell F (1985) Analysis of amiloride inhibition of chorda tympani taste response of rat to $\mathrm{NaCl}$. Am J Physiol 249:R52-R61.

Dohlman HG, Caron MG, Lefkowitz RJ (1987) A family of receptors coupled to guanine nucleotide regulatory proteins. Biochem 26:2657-2664.

Dohlman HG, Song J, Ma D, Courchesne WE, Thorner J (1996) Sst2, a negative regulator of pheromone signaling in the yeast Saccharomyces cerevisiae: expression, localization, and genetic interaction and physical association with Gpa1 (the G-protein alpha subunit). Mol Cell Biol 16:5194-5209.

Druey KM, Blumer KJ, Kang VH, Kehrl JH (1996) Inhibition of G-protein-mediated MAP kinase activation by a new mammalian gene family. Nature 379:742-746.

Eddy MC, Eschle BK, Barrows J, Hallock RM, Finger TE, Delay ER (2009) Double $\mathrm{P} 2 \mathrm{X} 2 / \mathrm{P} 2 \mathrm{X} 3$ purinergic receptor knockout mice do not taste $\mathrm{NaCl}$ or the artificial sweetener SC45647. Chem Senses 34:789-797.

Ferguson SS, Downey WE 3rd, Colapietro AM, Barak LS, Menard L, Caron MG (1996)

Role of beta-arrestin in mediating agonist-promoted G protein-coupled receptor internalization. Science 271:363-366.

Finger TE (2005) Cell Types and Lineages in Taste Buds. Chem Senses 30:i54-i55.

Finger TE, Danilova V, Barrows J, Bartel DL, Vigers AJ, Stone L, Hellekant G, Kinnamon SC (2005) ATP Signaling Is Crucial for Communication from Taste Buds to Gustatory Nerves. Science 310:1495-1499.

Freedman NJ, Lefkowitz RJ (1996) Desensitization of G protein-coupled receptors. Recent Prog Horm Res 51:319-353. 
Freissmuth M, Casey P, Gilman A (1989) G proteins control diverse pathways of transmembrane signaling. FASEB J 3:2125-2131.

Ganchrow JR, Steiner JE, Daher M (1983) Neonatal facial expressions in response to different qualities and intensities of gustatory stimuli. Infant Behav Dev 6:473-484. Gilman AG (1987) G Proteins: Transducers of Receptor-Generated Signals. Ann Rev Biochem 56:615-649.

Goldsmith ZG, Dhanasekaran DN (2007) G Protein regulation of MAPK networks.

Oncogene 26:3122-3142.

Gudermann T, Kalkbrenner F, Schultz G (1996) Diversity and Selectivity of Receptor-G Protein Interaction. Annu Rev Pharmacol Toxicol 36:429-459.

Guth L (1958) Taste buds on the cat's circumvallate papilla after reinnervation by glossopharyngeal, vagus, and hypoglossal nerves. Anatom Rec 130:25-37.

Hamm HE (1998) The many faces of G protein signaling. J Biol Chem 273:669-672.

He W, Cowan CW, Wensel TG (1998) RGS9, a GTPase accelerator for phototransduction. Neuron 20:95-102.

Heck GL, Mierson S, DeSimone JA (1984) Salt taste transduction occurs through an amiloride-sensitive sodium transport pathway. Science 223:403-405.

Hepler JR, Gilman AG (1992) G proteins. Trends Biochem Sci 17:383-387.

Hernandez PA, Gorlin RJ, Lukens JN, Taniuchi S, Bohinjec J, Francois F, Klotman ME, Diaz GA (2003) Mutations in the chemokine receptor gene CXCR4 are associated with WHIM syndrome, a combined immunodeficiency disease. Nat Genet 34:7074.

Hisatsune C, Yasumatsu K, Takahashi-Iwanaga H, Ogawa N, Kuroda Y, Yoshida R, 
Ninomiya Y, Mikoshiba K (2007) Abnormal taste perception in mice lacking the type 3 inositol 1,4,5-trisphosphate receptor. J Biol Chem 282:37225-37231.

Hoffman PW, Ravindran A, Huganir RL (1994) Role of phosphorylation in desensitization of acetylcholine receptors expressed in Xenopus oocytes. $J$ Neurosci 14:4185-4195.

Hoon MA, Adler E, Lindemeier J, Battey JF, Ryba NJP, Zuker CS (1999) Putative Mammalian Taste Receptors: A Class of Taste-Specific GPCRs with Distinct Topographical Selectivity. Cell 96:541-551.

Hoon MA, Northup JK, Margolskee RF, Ryba NJ (1995) Functional expression of the taste specific G-protein, alpha-gustducin. Biochem J 309:629-636.

Hu G, Wensel TG (2002) R9AP, a membrane anchor for the photoreceptor GTPase accelerating protein, RGS9-1. Proc Natl Acad Sci 99:9755-9760.

Huang L, Shanker YG, Dubauskaite J, Zheng JZ, Yan W, Rosenzweig S, Spielman AI, Max M, Margolskee RF (1999) Gy13 colocalizes with gustducin in taste receptor cells and mediates IP3 responses to bitter denatonium. Nat Neurosci 2:1055-1062.

Huang Y, Dando R, Roper S (2009) Autocrine and paracrine roles for ATP and serotonin in mouse taste buds. J Neurosci 29:13909-13918.

Hunt TW, Fields TA, Casey PJ, Peralta EG (1996) RGS10 is a selective activator of Gai GTPase activity. Nature 383:175-177.

Hwang PM, Verma A, Bredt DS, Snyder SH (1990) Localization of phosphatidylinositol signaling components in rat taste cells: role in bitter taste transduction. Proc Natl Acad Sci 87:7395-7399.

Inglese J, Koch WJ, Caron MG, Lefkowitz RJ (1992) Isoprenylation in regulation of 
signal transduction by G-protein-coupled receptor kinases. Nature 359:147-150.

Jaiswal M, Gremer L, Dvorsky R, Haeusler LC, Cirstea IC, Uhlenbrock K, Ahmadian MR (2011) Mechanistic insights into specificity, activity, and regulatory elements of the Regulator of G-protein Signaling (RGS)-containing Rho-specific guanine nucleotide exchange factors (GEFs) p115, PDZ-RhoGEF (PRG), and Leukemia-associated RhoGEF (LARG). J Biol Chem 286:18202-18212.

Jones TLZ (2004) Role of palmitoylation in RGS protein function. Methods Enzymol 389:33-55.

Kataoka S, Baquero A, Yang D, Shultz N, Vandenbeuch A, Ravid K, Kinnamon SC, Finger TE (2012) A2BR adenosine receptor modulates sweet taste in circumvallate taste buds. PLoS One 7:e30032.

Kataoka S, Toyono T, Seta Y, Ogura T, Toyoshima K (2004) Expression of P2Y 1 receptors in rat taste buds. Histochem Cell Biol 121:419-426.

Keresztes G, Martemyanov KA, Krispel CM, Mutai H, Yoo PJ, Maison SF, Burns ME, Arshavsky VY, Heller S (2004) Absence of the RGS9·Gß5 GTPase-activating Complex in Photoreceptors of the R9AP Knockout Mouse. J Biol Chem 279:15811584.

Kikuchi A (1999) Modulation of Wnt signaling by Axin and Axil. Cytokine Growth Factor Rev 10:255-265.

Kimple AJ, Garland AL, Cohen SP, Setola V, Willard FS, Zielinski T, Lowery RG, Tarran R, Siderovski DP (2014) RGS21, a regulator of taste and mucociliary clearance? Laryngoscope 124:E56-E63.

Kimple RJ, De Vries L, Tronchère H, Behe Cl, Morris RA, Farquhar MG, Siderovski DP 
(2001) RGS12 and RGS14 GoLoco motifs are G alpha(i) interaction sites with guanine nucleotide dissociation inhibitor Activity. J Biol Chem 276:29275-29281.

Kinnamon JC, Sherman TA, Roper SD (1988) Ultrastructure of mouse vallate taste buds: III. Patterns of synaptic connectivity. J Comp Neurol 270:1-10, 56-57.

Kinnamon SC, Finger TE (2013) A taste for ATP: neurotransmission in taste buds. Front Cell Neurosci 7:264.

Koelle MR, Horvitz HR (1996) EGL-10 regulates G protein signaling in the C. elegans nervous system and shares a conserved domain with many mammalian proteins. Cell 84:115-125.

Kozasa T, Jiang X, Hart MJ, Sternweis PM, Singer WD, Gilman AG, Bollag G, Sternweis PC (1998) p115 RhoGEF, a GTPase activating protein for Galpha12 and Galpha13. Science 280:2109-2111.

Krispel CM, Chen C-K, Simon MI, Burns ME (2003) Prolonged photoresponses and defective adaptation in rods of Gbeta5-/- mice. J Neurosci 23:6965-6971.

Kusakabe Y, Yasuoka A, Asano-Miyoshi M, Iwabuchi K, Matsumoto I, Arai S, Emori Y, Abe K (2000) Comprehensive study on G protein alpha-subunits in taste bud cells, with special reference to the occurrence of Galphai2 as a major Galpha species. Chem Senses 25:525-531.

Lambright DG, Noel J, P., Hamm H, E., Sigler P, B. (1994) Structural determinants for activation of the $\alpha$-subunit of a heterotrimeric $G$ protein. Nature 369:621-628.

Lambright DG, Sondek J, Bohm A, Skiba NP, Hamm HE, Sigler PB (1996) The $2.0 \AA$ crystal structure of a heterotrimeric G protein. Nature 379:311-319.

Lawton DM, Furness DN, Lindemann B, Hackney CM (2000) Localization of the 
glutamate-aspartate transporter, GLAST, in rat taste buds. Eur J Neurosci $12: 3163-3171$.

Lefkowitz RJ (1998) G protein-coupled receptors. III. New roles for receptor kinases and beta-arrestins in receptor signaling and desensitization. J Biol Chem 273:1867718680.

Lewandowski BC, Sukumaran SK, Margolskee RF, Bachmanov AA (2016) AmilorideInsensitive Salt Taste Is Mediated by Two Populations of Type III Taste Cells with Distinct Transduction Mechanisms. J Neurosci 36:1942-1953.

Li X, Chen L, Ji C, Liu B, Gu J, Xu J, Zou X, Gu S, Mao Y (2005) Isolation and expression pattern of RGS21 gene, a novel RGS member. Acta Biochim Pol $52: 943-946$.

Li X, Staszewski L, Xu H, Durick K, Zoller M, Adler E (2002) Human receptors for sweet and umami taste. Proc Natl Acad Sci 99:4692-4696.

Lohse MJ, Benovic JL, Codina J, Caron MG, Lefkowitz RJ (1990) beta-Arrestin: a protein that regulates beta-adrenergic receptor function. Science 248:1547-1550.

Lorenz W, Inglese J, Palczewski K, Onorato JJ, Caron MG, Lefkowitz RJ (1991) The receptor kinase family: primary structure of rhodopsin kinase reveals similarities to the beta-adrenergic receptor kinase. Proc Natl Acad Sci 88:8715-8719.

Luttrell LM, Ferguson SS, Daaka Y, Miller WE, Maudsley S, Della Rocca GJ, Lin F, Kawakatsu H, Owada K, Luttrell DK, Caron MG, Lefkowitz RJ (1999) $\beta$-arrestindependent formation of $\beta 2$ adrenergic receptor-Src protein kinase complexes. Science 283:655-661.

Luttrell LM, Roudabush FL, Choy EW, Miller WE, Field ME, Pierce KL, Lefkowitz RJ 
(2001) Activation and targeting of extracellular signal-regulated kinases by betaarrestin scaffolds. Proc Natl Acad Sci 98:2449-2454.

Makino ER, Handy JW, Li T, Arshavsky VY (1999) The GTPase activating factor for transducin in rod photoreceptors is the complex between RGS9 and type $5 \mathrm{G}$ protein beta subunit. Proc Natl Acad Sci 96:1947-1952.

Malach E, Shaul ME, Peri I, Huang L, Spielman Al, Seger R, Naim M (2015)

Membrane-permeable tastants amplify $\beta 2$-adrenergic receptor signaling and delay receptor desensitization via intracellular inhibition of GRK2's kinase activity. Biochim Biophys Acta 1850:1375-1388.

Mao H, Zhao Q, Daigle M, Ghahremani MH, Chidiac P, Albert PR (2004) RGS17/RGSZ2, a Novel Regulator of Gi/o, Gz, and Gq Signaling. J Biol Chem 279:26314-26322.

Marcus S, Polverino A, Barr M, Wigler M (1994) Complexes between STE5 and components of the pheromone-responsive mitogen-activated protein kinase module. Proc Natl Acad Sci 91:7762-7766.

Marinissen MJ, Gutkind JS (2001) G-protein-coupled receptors and signaling networks: emerging paradigms. Trends Pharmol Sci 22:368-376.

Martemyanov KA, Lishko P V, Calero N, Keresztes G, Sokolov M, Strissel KJ, Leskov IB, Hopp JA, Kolesnikov A V, Chen C-K, Lem J, Heller S, Burns ME, Arshavsky VY (2003) The DEP domain determines subcellular targeting of the GTPase activating protein RGS9 in vivo. J Neurosci 23:10175-10181.

McDonald PH, Chow CW, Miller WE, Laporte SA, Field ME, Lin FT, Davis RJ, Lefkowitz RJ (2000) Beta-arrestin 2: a receptor-regulated MAPK scaffold for the activation of 
JNK3. Science 290:1574-1577.

McLaughlin SK, McKinnon PJ, Margolskee RF (1992) Gustducin is a taste-cell-specific

G protein closely related to the transducins. Nature 357:563-569.

Meyerhof W (2005) Elucidation of mammalian bitter taste. Rev Physiol Biochem Pharmacol 154:37-72.

Ming D, Ninomiya Y, Margolskee RF (1999) Blocking taste receptor activation of gustducin inhibits gustatory responses to bitter compounds. Proc Natl Acad Sci 96:9903-9908.

Ming D, Ruiz-Avila L, Margolskee RF (1998) Characterization and solubilization of bitter-responsive receptors that couple to gustducin. Proc Natl Acad Sci 95:89338938.

Miyoshi MA, Abe K, Emori Y (2001) IP(3) receptor type 3 and PLCbeta2 are coexpressed with taste receptors T1R and T2R in rat taste bud cells. Chem Senses 26:259-265.

Montmayeur JP, Liberles SD, Matsunami H, Buck LB (2001) A candidate taste receptor gene near a sweet taste locus. Nat Neurosci 4:492-498.

Morrison DK, Davis RJ (2003) Regulation of MAP kinase signaling modules by scaffold proteins in mammals. Ann Rev Cell Dev Biol 19:91-118.

Mueller KL, Hoon MA, Erlenbach I, Chandrashekar J, Zuker CS, Ryba NJP (2005) The receptors and coding logic for bitter taste. Nature 434:225-230.

Murata Y, Yasuo T, Yoshida R, Obata K, Yanagawa Y, Margolskee RF, Ninomiya Y (2010) Action Potential-Enhanced ATP Release From Taste Cells Through Hemichannels. J Neurophsiol 104:896-901. 
Murray RG (1993) Cellular relations in mouse circumvallate taste buds. Microsc Res Tech 26:209-224.

Murray RG, Murray A (1967) Fine structure of taste buds of rabbit foliate papillae. J Ultrastruct Res 19:327-353.

Naim M, Seifert R, Nürnberg B, Grünbaum L, Schultz G (1994) Some taste substances are direct activators of G-proteins. Biochem J 297 ( Pt 3):451-454.

Neer EJ (1995) Heterotrimeric G proteins: organizers of transmembrane signals. Cell $80: 249-257$.

Neer EJ, Clapham DE (1988) Roles of G protein subunits in transmembrane signalling. Nature 333:129-134.

Nelson G, Chandrashekar J, Hoon MA, Feng L, Zhao G, Ryba NJP, Zuker CS (2002) An amino-acid taste receptor. Nature 416:199-202.

Nelson G, Hoon MA, Chandrashekar J, Zhang Y, Ryba NJ, Zuker CS (2001) Mammalian sweet taste receptors. Cell 106:381-390.

Nilsson B (1979) The occurrence of taste buds in the palate of human adults as evidenced by light microscopy. Acta odontol Scand 37:253-258.

Nishiguchi KM, Sandberg MA, Kooijman AC, Martemyanov KA, Pott JWR, Hagstrom SA, Arshavsky VY, Berson EL, Dryja TP (2004) Defects in RGS9 or its anchor protein R9AP in patients with slow photoreceptor deactivation. Nature 427:75-78.

Oakley RH, Laporte SA, Holt JA, Barak LS, Caron MG (1999) Association of $\beta$-Arrestin with G Protein-coupled Receptors during Clathrin-mediated Endocytosis Dictates the Profile of Receptor Resensitization. J Biol Chem 274:32248-32257. Offermanns S (2003) G-proteins as transducers in transmembrane signalling. Prog 
Biophys Mol Biol 83:101-130.

Oka Y, Butnaru M, von Buchholtz L, Ryba NJP, Zuker CS (2013) High salt recruits aversive taste pathways. Nature 494:472-475.

Pack TF, Orlen MI, Ray C, Peterson SM, Caron MG (2018) The dopamine D2 receptor can directly recruit and activate GRK2 without G protein activation. J Biol Chem:jbc.RA117.001300.

Peri I, Mamrud-Brains H, Rodin S, Krizhanovsky V, Shai Y, Nir S, Naim M (2000) Rapid entry of bitter and sweet tastants into liposomes and taste cells: implications for signal transduction. Am J Physiol Cell Physiol 278:C17-C25.

Pierce KL, Lefkowitz RJ (2001) Classical and new roles of $\beta$-arrestins in the regulation of G-PROTEIN-COUPLED receptors. Nat Rev Neurosci 2:727-733.

Pitcher JA, Freedman NJ, Lefkowitz RJ (1998) G Protein - Coupled Receptor Kinases. Annu Rev Biochem 67:653-692.

Pitcher JA, Inglese J, Higgins JB, Arriza JL, Casey PJ, Kim C, Benovic JL, Kwatra MM, Caron MG, Lefkowitz RJ (1992) Role of beta gamma subunits of G proteins in targeting the beta-adrenergic receptor kinase to membrane-bound receptors. Science 257:1264-1267.

Premont RT, Koch WJ, Inglese J, Lefkowitz RJ (1994) Identification, purification, and characterization of GRK5, a member of the family of G protein-coupled receptor kinases. J Biol Chem 269:6832-6841.

Pumplin DW, Yu C, Smith D V (1997) Light and dark cells of rat vallate taste buds are morphologically distinct cell types. J Comp Neurol 378:389-410.

Rajagopal S, Shenoy SK (2018) GPCR desensitization: Acute and prolonged phases. 
Cell Signal 41:9-16.

Rodbell M (1985) Programmable messengers: a new theory of hormone action. Trends Biochem Sci 10:461-464.

Roper SD (2015) The taste of table salt. Pflugers Arch Eur J Physiol 467:457-463.

Roper SD, Chaudhari N (2017) Taste buds: cells, signals and synapses. Nat Rev Neurosci 18:485-497.

Royer SM, Kinnamon JC (1991) HVEM serial-section analysis of rabbit foliate taste buds: I. Type III cells and their synapses. J Comp Neurol 306:49-72.

Ruiz CJ, Wray K, Delay ER, Margolskee RF, Kinnamon SC (2003) Behavioral evidence for a role of $\alpha$-gustducin in glutamate taste. Chem Senses 28:573-579.

Schiff ML, Siderovski DP, Jordan JD, Brothers G, Snow B, De Vries L, Ortiz DF, Diversé-Pierluissi M (2000) Tyrosine-kinase-dependent recruitment of RGS12 to the N-type calcium channel. Nature 408:723-727.

Scholich K, Mullenix JB, Wittpoth C, Poppleton HM, Pierre SC, Lindorfer MA, Garrison JC, Patel TB (1999) Facilitation of signal onset and termination by adenylyl cyclase. Science 283:1328-1331.

Shindo Y, Miura H, Carninci P, Kawai J, Hayashizaki Y, Ninomiya Y, Hino A, Kanda T, Kusakabe Y (2008) Ga14 is a candidate mediator of sweet/umami signal transduction in the posterior region of the mouse tongue. Biochem Biophys Res Commun 376:504-508.

Shu F, Ramineni S, Hepler JR (2010) RGS14 is a multifunctional scaffold that integrates G protein and Ras/Raf MAPkinase signalling pathways. Cell Signal 22:366-376. Siderovski DP, Diversé-Pierluissi M, De Vries L (1999) The GoLoco motif: a Galphai/o 
binding motif and potential guanine-nucleotide exchange factor. Trends Biochem Sci 24:340-341.

Siderovski DP, Hessel A, Chung S, Mak TW, Tyers M (1996) A new family of regulators of G-protein-coupled receptors? Curr Biol 6:211-212.

Siderovski DP, Willard FS (2005) The GAPs, GEFs, and GDIs of heterotrimeric Gprotein alpha subunits. Int J Biol Sci 1:51-66.

Simon MI, Strathmann MP, Gautam N (1991) Diversity of G proteins in signal transduction. Science 252:802-808.

Spink KE, Polakis P, Weis WI (2000) Structural basis of the Axin-adenomatous polyposis coli interaction. EMBO J 19:2270-2279.

Tarrant TK, Billard MJ, Timoshchenko RG, McGinnis MW, Serafin DS, Foreman O, Esserman DA, Chao NJ, Lento WE, Lee DM, Patel D, Siderovski DP (2013) G protein-coupled receptor kinase-3-deficient mice exhibit WHIM syndrome features and attenuated inflammatory responses. J Leukoc Biol 94:1243-1251.

Taruno A, Vingtdeux V, Ohmoto M, Ma Z, Dvoryanchikov G, Li A, Adrien L, Zhao H, Leung S, Abernethy M, Koppel J, Davies P, Civan MM, Chaudhari N, Matsumoto I, Hellekant G, Tordoff MG, Marambaud P, Foskett JK (2013) CALHM1 ion channel mediates purinergic neurotransmission of sweet, bitter and umami tastes. Nature 495:223-226.

Tordoff MG, Ellis HT, Aleman TR, Downing A, Marambaud P, Foskett JK, Dana RM, McCaughey SA (2014) Salty taste deficits in CALHM1 knockout mice. Chem Senses 39:515-528.

Tsao P, von Zastrow M (2000) Downregulation of G protein-coupled receptors. Curr 
Opin Neurobiol 10:365-369.

Tu Y-H, Cooper AJ, Teng B, Chang RB, Artiga DJ, Turner HN, Mulhall EM, Ye W, Smith AD, Liman ER (2018) An evolutionarily conserved gene family encodes protonselective ion channels. Science 359:1047-1050.

Vandenbeuch A, Anderson CB, Parnes J, Enjyoji K, Robson SC, Finger TE, Kinnamon SC (2013) Role of the ectonucleotidase NTPDase2 in taste bud function. Proc Natl Acad Sci 110:14789-14794.

Vandenbeuch A, Clapp TR, Kinnamon SC (2008) Amiloride-sensitive channels in type I fungiform taste cells in mouse. BMC Neurosci 9:1-13.

Vandenbeuch A, Larson ED, Anderson CB, Smith SA, Ford AP, Finger TE, Kinnamon SC (2015) Postsynaptic P2X3-containing receptors in gustatory nerve fibres mediate responses to all taste qualities in mice. J Physiol 593:1113-1125.

von Buchholtz L, Elischer A, Tareilus E, Gouka R, Kaiser C, Breer H, Conzelmann S (2004) RGS21 is a novel regulator of G protein signalling selectively expressed in subpopulations of taste bud cells. Eur J Neurosci 19:1535-1544.

Von Zastrow M, Kobilka BK (1992) Ligand-regulated internalization and recycling of human $\beta 2$-adrenergic receptors between the plasma membrane and endosomes containing transferrin receptors. J Biol Chem 267:3530-3538.

Vuong TM, Chabre M (1991) Deactivation kinetics of the transduction cascade of vision. Proc Natl Acad Sci 88:9813-9817.

Watson N, Linder ME, Druey KM, Kehrl JH, Blumer KJ (1996) RGS family members: GTPase-activating proteins for heterotrimeric G-protein alpha-subunits. Nature 383:172-175. 
Willard FS, Willard MD, Kimple AJ, Soundararajan M, Oestreich EA, Li X, Sowa NA, Kimple RJ, Doyle DA, Der CJ, Zylka MJ, Snider WD, Siderovski DP (2009) Regulator of G-protein signaling 14 (RGS14) is a selective H-Ras effector. PLoS One $4: e 4884$.

Willard MD, Willard FS, Li X, Cappell SD, Snider WD, Siderovski DP (2007) Selective role for RGS12 as a Ras/Raf/MEK scaffold in nerve growth factor-mediated differentiation. EMBO J 26:2029-2040.

Wong GT, Gannon KS, Margolskee RF (1996) Transduction of bitter and sweet taste by gustducin. Nature 381:796-800.

Woodard GE, Jardín I, Berna-Erro A, Salido GM, Rosado JA (2015) Regulators of GProtein-Signaling Proteins: Negative Modulators of G-Protein-Coupled Receptor Signaling. Int Rev Cell Mol Biol 317:97-183.

Yang R, Crowley HH, Rock ME, Kinnamon JC (2000) Taste cells with synapses in rat circumvallate papillae display SNAP-25-like immunoreactivity. J Comp Neurol 424:205-215.

Ye W, Chang RB, Bushman JD, Tu Y-H, Mulhall EM, Wilson CE, Cooper AJ, Chick WS, Hill-Eubanks DC, Nelson MT, Kinnamon SC, Liman ER (2016) The K + channel K IR 2.1 functions in tandem with proton influx to mediate sour taste transduction. Proc Natl Acad Sci 113:E229-E238.

Yee CL, Yang R, Böttger B, Finger TE, Kinnamon JC (2001) "Type IIl" cells of rat taste buds: immunohistochemical and ultrastructural studies of neuron-specific enolase, protein gene product 9.5, and serotonin. J Comp Neurol 440:97-108.

Yu JH, Wieser J, Adams TH (1996) The Aspergillus FlbA RGS domain protein 
antagonizes $\mathrm{G}$ protein signaling to block proliferation and allow development. EMBO J 15:5184-5190.

Zhang Y, Hoon MA, Chandrashekar J, Mueller KL, Cook B, Wu D, Zuker CS, Ryba NJP (2003) Coding of sweet, bitter, and umami tastes: Different receptor cells sharing similar signaling pathways. Cell 112:293-301.

Zhao GQ, Zhang Y, Hoon MA, Chandrashekar J, Erlenbach I, Ryba NJP, Zuker CS (2003) The receptors for mammalian sweet and umami taste. Cell 115:255-266.

Zubare-Samuelov M, Shaul ME, Peri I, Aliluiko A, Tirosh O, Naim M (2005) Inhibition of signal termination-related kinases by membrane-permeant bitter and sweet tastants: potential role in taste signal termination. Am J Physiol Cell Physiol 289:C483-C492. 


\title{
Chapter Two
}

\section{Development of full sweet, umami, and bitter taste responsiveness requires Regulator of G protein Signaling-21} (RGS21)

\author{
Original Article - Chemical Senses \\ Adam B. Schroer ${ }^{1}$, Joshua D. Gross ${ }^{1}$, Shane W. Kaski ${ }^{1}$, Kim Wix ${ }^{1}$, \\ David P. Siderovski ${ }^{1}$, Aurelie Vandenbeuch ${ }^{2}$, Vincent Setola ${ }^{1,3, *}$
}

${ }^{1}$ Department of Physiology, Pharmacology, and Neuroscience, West Virginia School of Medicine, One Medical Center Drive, Morgantown, WV 26506, USA, ${ }^{2}$ Department of Otolaryngology, University of Colorado - Denver, Anschutz Medical Campus, 12700 E. 19th Avenue, Aurora, CO 80045, USA,

${ }^{3}$ Department of Behavioral Medicine and Psychiatry, West Virginia School of Medicine, 930 Chestnut Ridge Road, Morgantown, WV 26505, USA

Correspondence to be sent to: Vincent Setola, West Virginia University School of Medicine, Morgantown, WV 26506-9229, USA. email: vssetola@hsc.wvu.edu 


\section{1 - Abstract}

The mammalian tastes of sweet, umami, and bitter are initiated by activation of $\mathrm{G}$ protein-coupled receptors (GPCRs) of the T1R and T2R families on taste receptor cells. GPCRs signal via nucleotide exchange and hydrolysis, the latter hastened by GTPaseaccelerating proteins (GAPs) that include the Regulators of G protein Signaling (RGS) protein family. We previously reported that RGS21, uniquely expressed in Plcb2+ taste receptor cells, decreases the potency of bitter-stimulated T2R signaling in cultured cells, consistent with its in vitro GAP activity. However, the role of RGS21 in organismal responses to GPCR-mediated tastants was not established. Here, we characterized mice lacking the Rgs21 fifth exon. Eliminating Rgs21 expression had no effect on body mass accumulation (a measure of alimentation), fungiform papillae number and morphology, circumvallate papillae morphology, and taste bud number and size. Twobottle preference tests, however, revealed that Rgs21-null mice have blunted aversion to quinine and denatonium, and blunted preference for monosodium glutamate, the sweeteners sucrose and SC45647, and $\mathrm{NaCl}$. Observed reductions in GPCR-mediated tastant responses upon Rgs21 loss are opposite to original expectations, given that loss of RGS21 -- a GPCR signaling negative regulator -- should lead to increased responsiveness to tastant-mediated GPCR signaling (all else being equal). Yet, reduced organismal tastant responses are consistent with observations of reduced chorda tympani nerve recordings in Rgs21-null mice. Reduced tastant-mediated responses and behaviors exhibited by adult mice lacking Rgs21 expression since birth have thus revealed an underappreciated requirement for a GPCR GAP to establish the full character of tastant signaling.

Key words: Gustatory, mouse, regulator of G protein signaling-21 (RGS21), taste buds, taste perception 


\section{2 - Introduction}

Taste perception is initiated by clusters of cells in the oral cavity known as taste buds. Type II taste receptor cells within taste buds express the chemosensory transduction proteins responsive to stimuli for the mammalian tastes of sweet, bitter, and umami (Clapp et al. 2004; DeFazio et al. 2006; Zhang et al. 2003). Stimuli for sweet and umami tastes are detected by the T1R family of G protein-coupled receptors (GPCRs) (Li et al. 2002; Nelson et al. 2001; Nelson et al. 2002; Zhao et al. 2003), while stimuli for bitter tastes are detected by a family of approximately 30 GPCRs, the T2Rs, most of which are expressed in the same subset of taste bud cells (Adler et al. 2000; Bufe et al. 2002; Chandrashekar et al. 2000). Downstream signaling by both T1R and T2R receptors in Type II taste cells is typically mediated by activation of a heterotrimeric $\mathrm{G}$ protein complex composed of $\mathrm{G} \alpha_{\text {gustducin }}$ (a.k.a. $\alpha$-gustducin), $\mathrm{G} \beta_{3}$, and $\mathrm{G} \gamma_{13}$ (Huang et al. 1999; McLaughlin et al. 1992; Ming et al. 1998; Wong et al. 1996). GPCR-mediated tastant signaling is primarily transduced by $\mathrm{G} \alpha$ nucleotide exchange and release of the G $\beta \gamma$ dimer, which in turn activates phospholipase C beta2 (PLC $\beta 2$ ) and, subsequently, the TRPM5 channel (Huang et al. 1999; Zhang et al. 2003). Opening of TRPM5 channels triggers membrane depolarization and extracellular release of ATP through the CALHM1 ion channel (Finger et al. 2005; Taruno et al. 2013), which in turn activates ATP-gated, ionotropic P2X2 and P2X3 receptors on gustatory afferent nerve fibers (Bo et al. 1999; Kinnamon and Finger 2013; Vandenbeuch et al. 2015b) and also metabotropic P2Y receptors on the Type II and Type III taste cells themselves (Bystrova et al. 2006; Huang et al. 2009; Kataoka et al. 2004). 
Tastants, upon binding to T1R or T2R GPCRs, induce guanine nucleotide exchange on the underlying heterotrimeric $G$ protein complex to release $G \beta \gamma$ from the $G \alpha$ subunit ( $\alpha$-gustducin or a related $\mathrm{G} \alpha$ subfamily member) (Hoon et al. 1995; Kusakabe et al. 2000; Ruiz et al. 2003; Shindo et al. 2008; Tizzano et al. 2008; Wong et al. 1996). As in other conventional GPCR signaling cascades, signaling of taste receptor cells as initiated by freed $G \beta \gamma$ is terminated when the intrinsic GTPase activity of the $G \alpha$ subunit hydrolyzes GTP to GDP, causing G $\beta \gamma$ re-association and thus restoration of the heterotrimeric G protein complex (reviewed in Palmer 2007; Siderovski and Willard 2005). In this way, downstream taste signal transduction is critically regulated by the rate of GTP hydrolysis by the $\mathrm{G} \alpha$ subunit.

Alpha-gustducin is most closely related structurally to the transducin subunits $\mathrm{G} \alpha$ t(rod) and $\mathrm{G}_{\mathrm{t}(\mathrm{cone})}$ found within rod and cone photoreceptors, respectively (McLaughlin et al. 1992). All three $\mathrm{G} \alpha$ subunits have similar (and slow) intrinsic GTPase activity, which determines the lifetime of a $\mathrm{G} \alpha$ subunit in its GTP-bound (active) form and, thus, the duration of heterotrimeric $G$ protein-based signal transduction. For $\alpha$-transducin subunits, a large discrepancy was observed early on between their slow observed GTPase activity in vitro and the rapid inactivation of phototransduction in vivo (Angleson and Wensel 1993). This timing paradox was resolved upon discovery of the Regulator of G protein Signaling (RGS) proteins (Druey et al. 1996; Koelle and Horvitz 1996; Siderovski et al. 1996) (reviewed in Kimple et al. 2011), which accelerate the rate of GTP hydrolysis by $\mathrm{G} \alpha$ subunits like $\alpha$-transducin in vitro (He et al. 1998) and in vivo (Chen et al. 2000). Thus, it is very likely that tastant signal transduction, which involves 
$\alpha$-gustducin and other $\mathrm{G} \alpha$ subunits, is similarly regulated by RGS-mediated GTPaseaccelerating protein (GAP) activity.

von Buchholtz and colleagues identified a putative Rgs gene transcript, Rgs21, from isolated rat foliate and fungiform papillae (von Buchholtz et al. 2004). In probing different rat tissues, these authors found that Rgs21 expression is restricted to taste tissue (von Buchholtz et al. 2004) -- specifically in a subpopulation of taste cells within all types of taste papillae (foliate, fungiform, circumvallate (CV), and palate). Furthermore, double-label in situ hybridization experiments revealed that virtually all cells expressing Rgs21 in rat lingual tissue also co-express $P / c \beta 2$, suggesting that Rgs21 is expressed exclusively in Type II taste receptor cells (von Buchholtz et al. 2004). Our subsequent biochemical analyses confirmed that purified RGS21 protein acts as a promiscuous GAP for multiple different $G \alpha$ subunits of the $G \alpha_{i / o}$ and $G \alpha_{q}$ subfamilies, including $\alpha$-gustducin and others involved in tastant signal transduction (Cohen et al. 2012; Kimple et al. 2014).

We demonstrated that Rgs 21 is not only endogenously expressed in mouse taste buds, but is also expressed in primary airway epithelial cells known to express other components of the tastant signaling cascade (Cohen et al. 2012; Kimple et al. 2014). Measuring the separate effects of RGS21 over- and under-expression in the tastantresponsive, immortalized human epithelial cell line 16HBE confirmed that RGS21 acts, in cell culture, to oppose bitter signaling to calcium second messenger changes (Cohen et al. 2012), consistent with its demonstrable G $\alpha$-directed GAP activity in vitro. However, it remained unclear what role(s), if any, RGS21 plays in integrated tastant responses emanating from lingual tissue upon exposure to one of the three GPCR- 
mediated taste modalities of sweet, umami, and bitter. Here, we describe the characterization of a mouse strain constitutively deficient in Rgs21 expression, including two-bottle choice tests for any altered preference/avoidance of umami (MSG), sweet, and bitter compounds; these behavioral findings were supported with complementary gustatory electrophysiology studies. 


\section{3 - Materials \& methods}

\subsection{1 - Subjects and maintenance}

All experiments involved Rgs21 wild-type and knockout mice; the latter mice lacked Rgs21 expression in a constitutive fashion, as described below. First, a conditional knockout of the Rgs21 gene was produced directly in the C57BL/6 background by genOway (Lyon, France). It involved insertion of loxP sites on either side of Rgs21 exon 5 (which encodes the final 67 amino-acids of the 152-amino acid RGS21 open-reading frame), as well as a neomycin-resistance gene (neo) flanked by "flippase recognition target" (FRT) sites, by homologous recombination in C57BL/6 embryonic stem cells. Drug-selected embryonic stem cells, with PCR and Southern blot evidence of homologous recombination, were subsequently injected into C57BL/6 blastocysts. Resulting chimeric male mice were crossed with females from the genOway proprietary ubiquitous Flp recombinase expressing mice for in vivo removal of the FRT-flanked neo selection cassette. F1 heterozygous $R g s 21^{f /+}$ mice devoid of the neo selection cassette were delivered by genOway to the Siderovski lab at WVU.

This conditional 'floxed' Rgs21 knockout strain was maintained at WVU by backcrossing to the $\mathrm{C} 57 \mathrm{BL} / 6 \mathrm{~J}$ strain. For this study, to obtain constitutive Rgs21-null mice, the 'floxed' Rgs21 mice were crossed with an ubiquitous Cre recombinase driver strain [B6.C-Tg(CMV-cre)1Cgn/J; JAX 006054] to generate Rgs21 ${ }^{\Delta 5 /+}$ mice. These $\operatorname{Rgs} 21^{\Delta 5 /+}$ mice were bred together to generate $\operatorname{Rgs} 21^{\Delta 5 / \Delta 5}$ (i.e., Rgs21-null) mice and Rgs $21^{+/+}$(i.e., wild-type) littermate control mice. Genotyping was performed via PCR using ear-snip tissue-derived genomic DNA and the following primer pairs: Shared Rgs21 allele forward primer 5'-CTGCCTTTGGGAAGCTTATG-3' (nts. 144520871 144520890 of GenBank NC_000067.6 [C57BL/6J chromosome 1]) with either wild-type 
Rgs21 allele reverse primer 5'-TGGTATGGTGGTGGTGTTGT-3' (nts. 144520654 144520673 of NC_000067.6) or with $\operatorname{Rgs} 21^{15}$ allele reverse primer 5'CATTTCAGGGTTTGGAAAAGTT-3' (nts. 144519608 - 144519629 of NC_000067.6).

Mice used in this study were maintained in a vivarium at $23{ }^{\circ} \mathrm{C}$ on a $12 \mathrm{~h} / 12 \mathrm{~h}$ light/dark cycle with lights off at 6 PM. They were housed in Allentown mouse cages $(194 \times 181 \times 398 \mathrm{~mm})$ with wire bar lids and corncob bedding, along with crinkled paper scattered on the floor for environmental enrichment. The mice had ad libitum access to Teklad Global 18\% Protein Rodent Diet (Envigo, Inc.) and water (except during exposure tests, see below). Pups were weaned at 21 days and initially housed in groups of the same sex. Body mass was initially recorded at weaning and subsequently every 2 weeks until mice were 9 weeks of age. All mice were at least 9 weeks old prior to subsequent animal testing. Mice used for gustatory electrophysiology were shipped from WVU to Dr. Vandenbeuch's laboratory at UC-Denver in Aurora, Colorado and allowed at least a week to recover before being tested. All procedures were approved by the Institutional Animal Care and Use Committee of the West Virginia University Health Sciences Center. Gustatory electrophysiological studies were also approved by the Animal Care and Use Committee of UC-Denver Anschutz Medical Campus.

\subsection{2 - RNA extraction}

Tongues were excised from mice euthanized with Fatal-Plus $₫$ in accordance with guidelines from the National Institute of Health and with approval from the West Virginia University IACUC. After treatment with an enzyme cocktail consisting of Dispase (3 $\mathrm{mg} / \mathrm{mL}$; Gibco) and Elastase (2.5 mg/mL; Worthington) in Tyrode's solution for $17 \mathrm{~min}$, the epithelium was peeled from the underlying tissue. Gustatory tissue was isolated from the $\mathrm{CV}$ and non-gustatory tissue was isolated from equivalent-sized, non-taste 
epithelial tissue surrounding the $\mathrm{CV}$ prior to being flash frozen for subsequent RNA extraction. Tissue was homogenized in TRIzol reagent (Invitrogen ${ }^{\mathrm{TM}}$ ) using a bench top rotor stator. RNA was extracted according to manufacturer's instructions using the Direct-zol ${ }^{\mathrm{TM}}$ RNA MiniPrep kit from Zymo Research. Reverse transcription and genomic DNA elimination was performed using the QuantiTect Reverse Transcription Kit from Qiagen.

\subsection{3 - Real-time quantitative reverse transcription-polymerase chain reaction (qRT-PCR)}

qRT-PCR was performed to compare the expression levels of 18S rRNA and Rgs21 mRNA in Rgs $21^{\Delta 5 / \Delta 5}$ mice and Rgs $21^{+/+}$littermate controls. Additionally, transcript levels of taste cell-specific markers were also assessed: ecto-nucleoside triphosphate diphosphohydrolase 2 (Entpd2) for Type I cells; transient receptor potential cation channel subfamily $\mathrm{M}$ member 5 (Trpm5), phospholipase C $\beta 2$ (Plb2), and calcium homeostasis modulator 1 (Calhm1) for Type II taste receptor cells; and synaptosomalassociated protein 25 (Snap25) for Type III cells. RNA extraction was performed as above. Two microliters of cDNA were used in each PCR reaction using the QuantiTect SYBR Green PCR Master Mix (Qiagen). RT ${ }^{2}$ qPCR Primer Assay for Mouse 18S rRNA was purchased from Qiagen. Primers $(10 \mu \mathrm{M})$ were designed for Rgs21 mRNA (spanning exons 4-5) sequence elements (fwd primer: 5'TCGTAGCTGATGCACCAAAA-3'; rev primer 5'-TACAGGAAAGGCAGCCATCT-3') and purchased from ThermoFisher Scientific. Primer sequences for taste cell-specific markers were described previously (Huang et al. 2011; Taruno et al. 2013) and were purchased from ThermoFisher Scientific. PCR was performed (initial 15 min 
denaturation at $95^{\circ} \mathrm{C}$ followed by 40 cycles of $15 \mathrm{~s}$ denaturation at $95^{\circ} \mathrm{C}, 30 \mathrm{~s}$ annealing at $60^{\circ} \mathrm{C}$, and $30 \mathrm{~s}$ extension at $72^{\circ} \mathrm{C}$ ) in a Qiagen Rotor Gene-Q system. We utilized the SYBR green dye qPCR technique to detect double-stranded PCR amplicons as they accumulated during PCR cycling. Melting curves were obtained after each qRT-PCR experiment to assure specificity of resultant amplicons.

\subsection{4 - Tongue morphology}

To assess general tongue morphology and number of fungiform papillae, tongues were dissected from $R g s 21^{+/+}$and $R g s 21^{\Delta 5 / \Delta 5}$ mice and briefly placed in $1 \%$ methylene blue (Ricca Chemical Co.). Tongues were then briefly rinsed in phosphate buffered saline. Methylene blue stains fungiform papillae more lightly than surrounding tissue, facilitating the quantification of taste papillae (Barnett et al. 2010). Images of the anterior dorsal surface of the tongue were taken using an Olympus SZX7 bright-field dissecting microscope with a Q-Fire CCD camera (Olympus America, Inc.). To ensure accuracy of scoring, two blinded investigators independently counted the number of fungiform papillae using the counter tool from ImageJ software to count and record all visible papillae on the anterior dorsal tongue. Subsequently, the independent counts were averaged. Images of the posterior tongue were also imported into ImageJ software to quantify the apical area of the CV papilla on each of these tongues. The freehand tool in ImageJ was used to trace around the interior wall of the papilla to quantify the total area of the papilla. Statistical analyses using unpaired Student's $t$ tests were applied to determine whether differences in fungiform number and apical CV area were significant between genotypes. 


\subsection{5 - Immunohistochemistry}

Tongues were excised from adult mice and placed in optimum cutting temperature (OCT) embedding compound (Sakura Finetech) prior to being flash frozen. Transverse sections (8- $\mu \mathrm{m}$ thick) of tongue containing the CV papilla were sliced using a cryostat and placed on Superfrost ${ }^{\mathrm{TM}}$ Microscope Slides (Fisherbrand ${ }^{\mathrm{TM}}$ ). Tissues sections were stained with hematoxylin and eosin (H\&E) and examined under a bright-field microscope (EVOS FL Auto). To assess taste bud number and size, immunohistochemistry was performed on CV papillae sections using the Troma-1 antibody (Developmental Studies Hybridoma Bank [DSHB]). The Troma-1 antibody has previously been characterized as specific using keratin-8 and -18 deficient mice (Tao et al. 2003). The Troma-1 antibody was used to label keratin-8, an intermediate filament protein in mature taste bud cells, to identify the boundary of taste buds (Toh et al. 1993; Zhang et al. 1995); Troma-1 has been shown to label taste bud cells with no labeling of stratified epithelium of the papilla wall (Liebl et al. 1999; Okubo et al. 2006; Seki et al. 2007). General labeling of taste bud cells with Troma-1 allowed for subsequent quantification of taste bud number and size. Tissue sections were fixed in $4 \%$ paraformaldehyde for $10 \mathrm{~min}$ at room temperature; membranes were then permeabilized in PBS with $0.05 \%$ Triton-X100 for $10 \mathrm{~min}$ on ice. After blocking by incubation of slides for 60 min in PBS containing $5 \%$ goat serum at room temperature, sections were incubated at $4^{\circ} \mathrm{C}$ overnight with Troma-1 primary antibody (1:50). The following day, slides were incubated with Alexa Fluor-555-conjugated anti-mouse secondary antibody (1:500; Molecular Probes) for 60 minutes at room temperature. 
Slides were cover-slipped with Vectashield Hardset Mounting Media containing DAPI. Images were acquired using a Zeiss Violet Confocal microscope in the West Virginia University Microscope Imaging Facility, supported by the WVU Cancer Institute and NIH grants P30GM103488 and P20GM103434. Two blind, independent investigators used ImageJ software to quantify the taste bud number and area from these images. Taste bud number was counted on at least four sections per $\mathrm{CV}$, with $80 \mu \mathrm{m}$ between sections, from four separate mice using the ImageJ counter tool to avoid double counting buds. The ImageJ freehand tool was used to trace around the exterior of the cluster of each individual Troma-1-labeled taste bud to quantify the area of each taste bud. Each mouse had the area of all taste buds in the CV averaged. Statistical analyses using unpaired Student's t tests were applied to determine whether differences in taste bud number or taste bud area were significant between genotypes.

\subsection{6 - In situ hybridization}

Tongue tissue sections from both genotypes of mice were provided to the Baylor College of Medicine's RNA In Situ Hybridization Core which performed non-radioactive, RNA in situ hybridization (ISH) using Trpm5 sense and antisense probes and a highthroughput protocol as previously described (Yaylaoglu et al. 2005). Images were acquired using a Zeiss Violet Confocal microscope, as stated above for IHC.

\subsection{7 - Two-bottle choice tests}

Two-bottle choice tests were conducted in large Thoren mouse cages $(30.80 \mathrm{~cm} \mathrm{x}$ $40.60 \mathrm{~cm} \times 15.88 \mathrm{~cm}$ ). Individually housed mice were given access to two bottles containing autoclaved distilled water for $48 \mathrm{~h}$ prior to beginning all choice testing. Fluid 
was available through sipper spouts attached to $50-\mathrm{mL}$ Corning ${ }^{\mathrm{TM}}$ conical-bottom centrifuge tubes, placed in separate bottle access slots on opposite sides of the food bin. Following the initial 48-h presentation of two bottles of water, mice were assessed over $48 \mathrm{~h}$ in tests with a choice between distilled water and ascending concentrations of a taste compound. The positions of the bottles were switched daily, and the fluid intakes were measured to the nearest $0.1 \mathrm{~g}$ by weighing the drinking bottles on an electronic balance. Preference ratio was calculated as volume of tastant solution consumed divided by volume of total solution consumed. The taste compounds were chosen as exemplars of the sweet, bitter, umami, salty, and sour taste qualities, and their concentrations spanned the range between indifference and marked acceptance or avoidance (Sucrose - 2.9, 14.6, 29.2, 58.5, and 292.4 mM; SC45647 - 0.003, 0.01, 0.03, $0.1,0.3$, and $1 \mathrm{mM}$; Denatonium Benzoate - 0.01, 0.1, 0.3, 1, and $5 \mathrm{mM}$; Quinine Sulfate $-0.003,0.01,0.03,0.1,0.3,0.6$, and $1 \mathrm{mM}$; Monosodium Glutamate [MSG; containing $10 \mu \mathrm{M}$ amiloride to block the taste of sodium] $-1,10,30,100,300,600$, and $1000 \mathrm{mM} ; \mathrm{NaCl}-18.75,37.5,75,150,300$, and $600 \mathrm{mM} ; \mathrm{HCl}-0.1,1,10$, and $30 \mathrm{mM}$ ). Mice naïve to the two-bottle choice assay were used to assess $\mathrm{NaCl}$ taste preference. The mice were socially housed for 7 days between each test series. At least 6 mice per genotype were assessed at each concentration of taste solution. Results were analyzed using a two-way ANOVA (genotype $\times$ concentration) with a Sidak multiple comparisons test (GraphPad Prism 7).

\subsection{8 - Nerve recording}

Chorda tympani nerve recordings were performed as previously described (Vandenbeuch et al. 2015a). Briefly, mice were anesthetized with urethane (2 g/kg), maintained in a head holder, and trachea cannulated to facilitate breathing. The chorda 
tympani nerve was exposed using a ventral approach, freed from surrounding tissue and cut near the tympanic bulla. The nerve was then placed on a platinum-iridium wire and a reference electrode was placed in a nearby tissue. The signal was fed to an amplifier (P511; Grass Instruments), integrated, and recorded using AcqKnowledge software (Biopac). For chorda tympani recordings, a total of $7-10$ Rgs21 ${ }^{\Delta 5 / \Delta 5}$ mice and 7-9 wild-type littermate control mice were used. The fungiform papillae were stimulated with different tastants (applied for $30 \mathrm{~s}$ and then rinsed with water for $40 \mathrm{~s}$ ) with a constant flow pump (Fisher Scientific). Each series of stimuli consisted of: $100 \mathrm{mM}$ $\mathrm{NH}_{4} \mathrm{Cl}, 100 \mathrm{mM}$ MSG + $0.5 \mathrm{mM}$ inosine monophosphate (IMP), $10 \mathrm{mM}$ quinine, $500 \mathrm{mM}$ sucrose, $5 \mathrm{mM} \mathrm{SC45657,} 100 \mathrm{mM} \mathrm{NaCl}, 10 \mathrm{mM} \mathrm{HCl}, 10 \mathrm{mM}$ citric acid (CA), and a second application of $100 \mathrm{mM} \mathrm{NH}_{4} \mathrm{Cl}$. Stimuli were randomly applied between the two $\mathrm{NH}_{4} \mathrm{Cl}$ applications; each series was repeated 2-3 times on each animal. To analyze the data, the amplitude of each integrated response was averaged over the 30-s application using AcqKnowledge software. Since no significant difference was observed between the separate $\mathrm{NH}_{4} \mathrm{Cl}$ responses at the beginning and at the end of each series (paired Student's t test; $p>0.05$ ), each tastant's responses were normalized to the average amplitude of $\mathrm{NH}_{4} \mathrm{Cl}$ applications. Responses to each stimulus were averaged per animal and compared between $R g s 21^{+/+}$and $\operatorname{Rgs} 21^{\Delta 5 / \Delta 5}$ mice with an unpaired Student's t test (GraphPad Prism 7). The grand mean was calculated and represented in Figure 6B. 


\section{4 - Results}

\subsection{1 - Development of Rgs21-null mice}

PCR amplification was used to determine the genotype of $R g s 21^{+/+}$and $R g s 21^{\Delta 5 / \Delta 5}$ mice. Specific primers, designed around the floxed exon 5 portion of $R g s 21$, were used to discriminate between mice with unexcised $\left(\operatorname{Rgs} 21^{+/+}\right)$and excised $\left(\operatorname{Rgs} 21^{\Delta 5 / \Delta 5}\right)$ genomic DNA (Figure 1). Real-time quantitative RT-PCR was used to confirm that Rgs21 mRNA expression is observable in tongue tissue and enriched in CV tissue, but absent in non-gustatory epithelial tissue (Figure 1E). Additionally, $R g s 21^{\Delta 5 / \Delta 5}$ mice lack the Rgs21 mRNA expression observable in $R g s 21^{+++}$whole tongue and CV tissues (Figure 1E).

\section{[Location of Figure 1]}

$\operatorname{Rgs} 21^{\Delta 5 / \Delta 5}$ mice were observed to be grossly phenotypically normal and, when bred from $R g s 21^{\Delta 5 /+} \times R g s 21^{\Delta 5 /+}$ crosses, were born in a normal Mendelian ratio of 1:2:1. In addition, $R g s 21^{\Delta 5 / \Delta 5}$ mice exhibited no differences in body weight gain compared with Rgs $21^{+/+}$littermates (Figure 2). These latter data suggest that no appetitive changes to regular nutritional sources (e.g., cage-delivered chow and water) occur upon the loss of Rgs21 expression.

\section{[Location of Figure 2]}

\subsection{2 - Normal lingual histology and complement of taste cell-specific markers in Rgs21-null mice}

To assess any changes to tastant-responsive lingual tissue composition and/or morphology, we first assessed general taste papillae morphology of methylene blue stained $R g s 21^{+/+}$and $R g s 21^{\Delta 5 / \Delta 5}$ tongues. WT and $R g s 21$-null mice had an equivalent 
number of fungiform papillae on the anterior tongue (Figure $3 A-C$ ). Additionally, the apical size of the CV was similar between WT and Rgs21-null mice (Figure 3D-F).

[Location of Figure 3]

The CV was also stained with hemotoxylin and eosin to assess qualitatively CV and taste bud morphology (Figure 2.4A-B). Taste bud and CV cross-sectional morphology appeared equivalent between Rgs21-null mice and wild-type littermate controls. To highlight taste buds, cross-sections of CV from $R g s 21^{+/+}$and $R g s 21^{\Delta 5 / \Delta 5}$ were also labeled with anti-keratin-8 (“Troma-1"; Figure 2.4D-E). To determine whether the overall quantity of tastant-receptive tissue is altered in the absence of Rgs21, the number and size of taste buds in each section were quantified using Troma-1 staining. Rgs $21^{\Delta 5 / \Delta 5}$ taste buds did not differ from Rgs $21^{+/+}$taste buds in number or size (Figure 4C,F), suggesting mice lacking Rgs21 develop taste-receptive lingual tissue normally. Furthermore, in situ hybridization for the Type II taste receptor cell marker Trpm5 revealed no differences between genotypes (e.g., Figure 4G-I); quantitative RT-PCR detection of Trpm5 mRNA and transcripts of other taste cell markers (Plcb2, Calhm1 for Type II cells, Entpd2 for Type I cells, and Snap25 for Type III cells) within taste epithelium isolated from the $\mathrm{CV}$ also revealed no differences in expression between genotypes (Figure 2.4J).

[Location of Figure 2.4]

\subsection{3 - Reduced responsiveness in two-bottle choice tests}

$R g s 21^{1 /+}$ and $\operatorname{Rgs} 21^{\Delta 5 / \Delta 5}$ mice underwent two-bottle choice testing to determine if Rgs21 contributes to the in vivo response to tastants sensed by GPCR taste receptors, i.e., tastants described as bitter, sweet, or umami. Rgs21-null mice showed a lack of aversion to quinine sulfate (Figure 2.5A) and a reduced aversion to denatonium 
benzoate (Figure 2.5B), tastants representing the bitter taste quality, which are mediated by the T2R family of GPCRs. Additionally, $\operatorname{Rgs} 21^{15 / \Delta 5}$ mice revealed reduced preference towards the sweetener sucrose (Figure $2.5 \mathrm{C}$ ). To ensure that the postingestive influence of sucrose is not influencing the altered response observed with Rgs21-null mice, we also tested preference for the non-caloric sweetener SC45647. $\operatorname{Rgs} 21^{\Delta 5 / \Delta 5}$ mice also showed reduced preference for SC45647 (Figure 2.5D). To assess whether umami taste is altered in $\operatorname{Rgs} 21^{\Delta 5 / \Delta 5}$ mice, we measured two-bottle choice using MSG. The preference for MSG was blunted in Rgs21-null mice, as they did not reach a peak preference ratio equivalent to that of wild-type mice (Figure 2.5E). All MSG solutions contained $10 \mu \mathrm{M}$ amiloride to block the effects of the sodium ion. Surprisingly, $\operatorname{Rgs} 21^{\Delta 5 / \Delta 5}$ mice lacked the appetitive response to moderate concentrations of $\mathrm{NaCl}$ seen in wild-type mice (Figure 2.5F), but showed no change in aversion to the sour tastant hydrochloric acid (Figure 2.5G).

[Location of Figure 5]

\subsection{4 - Blunted responses in chorda tympani nerve recordings}

To test whether Rgs21 loss affected the acute phase of taste responses post-lingual tissue engagement, we used $\operatorname{Rgs} 21^{\Delta 5 / \Delta 5}$ mice and $R g s 21^{+/+}$control littermates to perform chorda tympani whole-nerve recordings while stimulating the tongue with various taste stimuli. As shown in Figure 6, no significant difference was observed between the two mouse strains in the amplitude of responses to the sour tastants $\mathrm{HCl}$ and citric acid, as normalized to the average responses to $\mathrm{NH}_{4} \mathrm{Cl}$ recorded at the beginning and ending of the tastant series. In contrast, significantly depressed responses were seen in $R g s 2^{\Delta 5 / \Delta 5}$ mice for exposures to the bitterant quinine, the two sweeteners tested (sucrose and SC45647), and the joint application of two umami 
tastants (i.e., MSG and IMP; Figure 6B). In contrast to the behavioral response (Fig. $2.5 \mathrm{~F}$ ), a significant difference was not found for $R g s 21{ }^{5 / 5}$ mice in response to $100 \mathrm{mM}$ $\mathrm{NaCl}$. However, the remainder of these data are consistent with the overall behavioral responses (i.e., reduction of GPCR-mediated events, but not sour signaling; Figure 2.5) and thereby suggest that Rgs21 functions at the level of peripheral taste input in these taste qualities. While Rgs21 expression is thought to be limited to lingual (and airway) gustatory tissue (Cohen et al. 2012; Kimple et al. 2014; von Buchholtz et al. 2004), blunted preference towards moderate concentrations of $\mathrm{NaCl}$ may instead be the result of altered post-ingestive factors, hedonics, and/or central integration caused by Rgs 21 loss.

[Location of Figure 6] 


\section{5 - Discussion}

The principal finding of this study is that Rgs 21 expression, shown previously to be localized exclusively in cells expressing markers found in Type II taste cells (Cohen et al. 2012; von Buchholtz et al. 2004), is required for establishing the normal responsiveness of the mouse gustatory system to tastants that signal through GPCRs. Microscopy of tongues from $\operatorname{Rgs} 21^{\Delta 5 / \Delta 5}$ mice revealed apparently normal fungiform and circumvallate papillae; taste bud size and number within the CV also did not differ between wild-type and Rgs21-null mice (Figs. $2.3 \& 2.4$ ). The distribution of Trpm5+ cells and levels of other taste cell-specific transcripts, representing all three taste cell types, are unchanged in lingual tissue from $R g s 21^{\Delta 5 / \Delta 5}$ mice, demonstrating the presence of all taste cell types. These findings suggest that the reduced GPCRmediated (and salt) taste responsiveness of $R g s 21^{15 / \Delta 5}$ mice is unlikely to be explained by an abnormal development of lingual chemosensory tissue.

Observations of reduced responsiveness to bitter, sweet, and umami tastants upon Rgs21 loss run opposite to prior expectations built upon the general knowledge of RGS protein function as negative regulators of GPCR signaling (Lambert et al. 2010; Siderovski and Willard 2005; Woodard et al. 2015); moreover, these present observations from characterizing $R g s 21^{\Delta 5 / \Delta 5}$ mice run counter to our prior finding that acute Rgs21 knockdown in tastant-responsive epithelial cells leads to amplified intracellular second messenger responses upon exposure to bitter compounds (Cohen et al. 2012). Based centrally on the fact that RGS proteins like RGS21 accelerate inactivation of GPCR-activated $\mathrm{G} \alpha$ subunits (Berman et al. 1996; Cohen et al. 2012; Kimple et al. 2014; Snow et al. 1998; Watson et al. 1996), the absence of Rgs21 is 
expected to prolong, and therefore potentiate, the signaling of agonist-occupied GPCRs, such as the tastant-responsive T1Rs and T2Rs of taste receptor cells (Adler et al. 2000; Bufe et al. 2002; Chandrashekar et al. 2000; Li et al. 2002; Nelson et al. 2001; Nelson et al. 2002; Zhao et al. 2003). GPCR-targeting tastants should be more potent upon Rgs 21 loss, and thus we originally expected to observe a leftward shift in the dose-response curves for sweet/umami preference and bitter avoidance in Rgs21-null mice compared with wild-type littermates. Instead, a rightward shift was seen for preference to sucrose, SC45647, and monosodium glutamate, and for aversion to the bitter compounds quinine and denatonium. However, as expected, Rgs $21^{\Delta 5 / \Delta 5}$ mice showed no change in aversion to hydrochloric acid (Figure 2.5G), a tastant representing the sour taste quality. Sour taste responses are not mediated by GPCR signaling; rather, they are mediated by a $\mathrm{Zn}^{2+}$-sensitive proton conductance in Type III taste cells, which blocks the inwardly rectifying $\mathrm{K}^{+}$channel KIR2.1 (Chang et al. 2010; Tu et al. 2018; Ye et al. 2016).

An additional surprising observation was that $\operatorname{Rgs} 21^{45 / \Delta 5}$ mice had a reduced appetitive response to moderate concentrations of $\mathrm{NaCl}(37.5-150 \mathrm{mM}$; Figure 2.5F). While recent work has suggested that bitter-responsive taste cells mediate a portion of the aversive response to high $\mathrm{NaCl}$ concentrations (Oka et al. 2013), appetitive responses to moderate $\mathrm{NaCl}$ concentrations are thought to be mediated by a separate population of amiloride-sensitive taste cells, independent of Type II and III taste cells (Chandrashekar et al. 2010; Vandenbeuch et al. 2008). Others have suggested that amiloride-sensitive taste cells may transduce salt taste information to the afferent nerve, at least in part, via GPCR-mediated communication with Type II cells (Tordoff et al. 
2014). However, evidence of GPCR signaling in Type II taste cells mediating the appetitive response to moderate $\mathrm{NaCl}$ concentrations has been inconsistently observed (Damak et al. 2006; Hisatsune et al. 2007; Wong et al. 1996; Zhang et al. 2003). Additionally, $\operatorname{Rgs} 21^{\Delta 5 / \Delta 5}$ mice were not observed to have a statistically significant reduction of their CT nerve responses to $100 \mathrm{mM}$ of $\mathrm{NaCl}$, casting doubt on this hypothesized mechanism of amiloride-sensitive transmission. The reduced preference for moderate $\mathrm{NaCl}$ concentrations shown by $\mathrm{Rgs} 21^{\Delta 5 / \Delta 5}$ mice may therefore result from altered post-ingestive influences, including possible alterations to the renin-angiotensin system (Bachmanov et al. 2002; Sakamoto et al. 2016). This possibility is currently under investigation.

\section{Does loss of Rgs21 lead to desensitization of the GPCR-mediated taste system?}

Based upon the conventional function of RGS proteins, as well as our prior in vitro findings in tastant-responsive epithelial cells, loss of RGS21 in taste receptor cells is expected to result in prolonged signaling of taste GPCRs and, subsequently, a prolonged elevation of ATP release. Reduced responsiveness towards GPCR-mediated tastants in $\operatorname{Rgs} 21^{15 / \Delta 5}$ mice may be explained by desensitization at the level of the taste receptor and/or downstream signaling components. Hyperactivity of GPCRs commonly leads to phosphorylation and subsequent desensitization and down-regulation of the receptor (Freedman and Lefkowitz 1996; Luttrell and Lefkowitz 2002; Rajagopal and Shenoy 2018). In the event that elevated signaling upon Rgs21 loss does not desensitize the taste receptor cell directly, prolonged elevation of ATP release could desensitize downstream purinergic receptors, including those on the gustatory nerve fiber (North 2002); there is precedence for desensitization and loss of taste 
responsiveness with elevated extracellular ATP levels caused by genetic ablation (e.g., of the ectonucleotidase NTPDase2; Vandenbeuch et al. 2013).

\section{Precedence of bidirectional effects on GPCR signaling upon RGS protein loss}

In addition to the potential for Rgs21 loss to lead to desensitization, there is additional emerging evidence in the literature for bidirectional regulation of GPCR signaling by RGS proteins. For example, we used siRNA-mediated 'knock-down' of each of the 17 different RGS proteins expressed in HEK293 cells to examine the effects of RGS protein deficiency on endogenous GPCR-mediated cellular signaling (Laroche et al. 2010). Consistent with the original model wherein RGS protein deficiency increases GPCR agonist-mediated signaling, we found that RGS11 knockdown increased maximal muscarinic receptor-induced calcium flux (Laroche et al. 2010). The same effect was observed for knockdown of RGS2 on PAR-1 receptor-induced calcium flux (Laroche et al. 2010). However, RGS9 knock-down resulted in a decrease in both the potency and efficacy of the agonist carbachol on endogenous muscarinic receptor responses. Similarly, RGS8 knock-down yielded a decrease in maximal PAR-1 receptor-induced calcium flux (Laroche et al. 2010). These two latter results are compatible with an alternative model wherein RGS protein deficiency can lead to a decrease of agonist potency and/or efficacy at some GPCRs, which may be the case in Rgs21-null mice with respect to proximal umami (T1R1/2), sweet (T1R2/3), and bitter (T2R) signaling and/or supportive, autocrine purinergic receptor (P2Y1 and P2Y2) signaling. 


\section{Parallel to Rgs-3 function in C. elegans?}

There is precedence in another model organism for our present, mouse knockout strain-based observation of reduced taste responses upon the loss of an RGS protein. The selective distribution of Rgs21 in rodent and human taste cells (Cohen et al. 2012; Kimple et al. 2014; von Buchholtz et al. 2004) is reminiscent of the sensory-specific distribution in C. elegans of Rgs-3, which is found only in a subset of chemosensory neurons. Rgs-3-deficient C. elegans exhibit normal development and motor ability compared to wild-type nematodes, but they demonstrate an inability to respond to normal levels of chemoattractants such as isoamyl alcohol (Ferkey et al. 2007). RGS21 may play a similar role in dampening tastant signaling so that the mammalian gustatory system is not overwhelmed when tastants are too abundant on the lingual epithelium; in the absence of RGS protein GAP activity, normal exposure to GPCR-mediated tastants during lingual epithelium development may lead to compensatory desensitization or down-regulation of tastant response machinery. We are currently pursuing this particular hypothesis with temporally-controlled, conditional Rgs21 knockout approaches. 


\section{Funding}

This work was supported, in part, by the West Virginia University E.J. Van Liere Medicine Professorship and William W. Fleming Pharmacology Trust endowments [to D.P.S. and A.S., respectively]. Trpm5 in situ hybridization data were generated by the Baylor College of Medicine's RNA In Situ Hybridization Core supported by NIH grant S10 OD016167.

\section{Acknowledgements}

We thank Dr. Sue Kinnamon for provision of SC45647 and guidance throughout the conduct of this investigation. 


\section{6 - Figures}

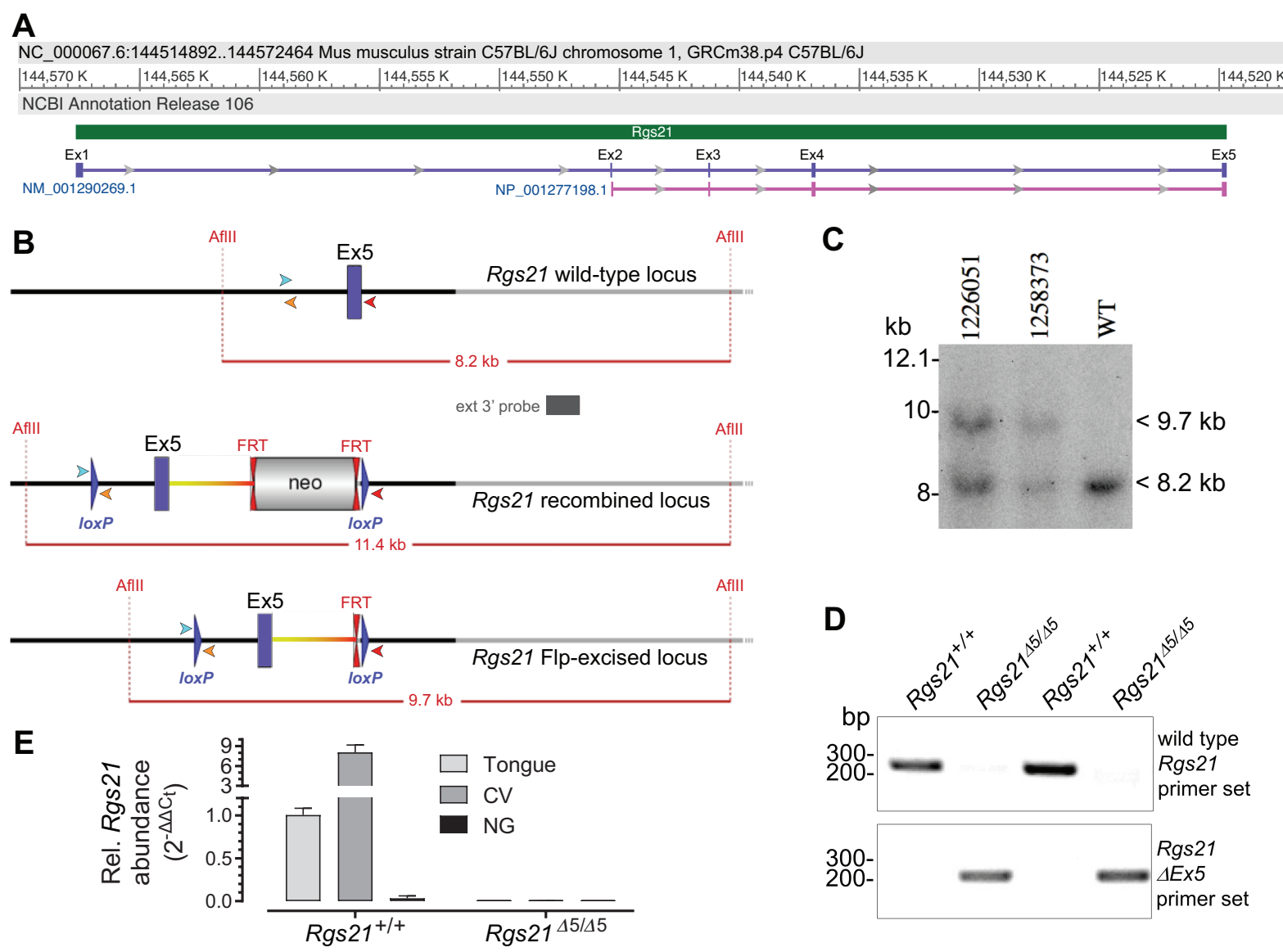

Figure 2.1. Genotype and gene expression validation of successful excision of Rgs21 exon 5 .

(A) Architecture of Rgs21 locus on chromosome 1 of C57BL/6J mice, as obtained from GenBank record NC_000067.6 and spanning its five exons (Ex1 - Ex5) as denoted by its RNA transcript (NM_001290269, purple) and its encoded RGS21 polypeptide (NP_001277198.1, pink). (B) Illustration of wild-type Rgs21 surrounding exon 5, the predicted insertion of loxP recombination sites and neomycin ("neo") selection cassette by homologous recombination, and the predicted result of Flp recombinase excision. Forward (cyan) and reverse (orange, red) primers used in detecting Cre-mediated recombination of loxP sites are indicated as arrowheads. (C) Southern blot validation of 
successful Flp recombinase excision of neo cassette, based on Afll digestion of genomic DNA from indicated mice (or C57BL/6 control mouse, "WT"), subsequent blotting on nylon membrane, and hybridization with an external 3' DNA probe (indicated in panel B). (D) Ear-punch DNA samples from four indicated progeny of an $R g s 21^{\Delta 5 /+} \mathrm{X}$ Rgs $21^{\Delta 5 /+}$ mating were genotyped by PCR. Specific primers (denoted in panel B) were designed around the floxed exon 5 portion of $R g s 21$ to discriminate between unexcised $\left(R g s 21^{+/+}\right)$and Cre recombinase-excised $\left(R g s 21^{\Delta 5 / \Delta 5}\right)$ genomic DNA. (E) Data from qRT-PCR (SYBR Green detection) of the Rgs21 mRNA transcript, which is seen to be completely absent in Rgs $21^{\Delta 5 / \Delta 5}$ mice and absent in non-gustatory ("NG") epithelial tissue from $R g s 21^{+/+}$mice, but detectable in tongue and enriched in circumvallate papillae ("CV") tissue from $R g s 21^{+/+}$mice. 


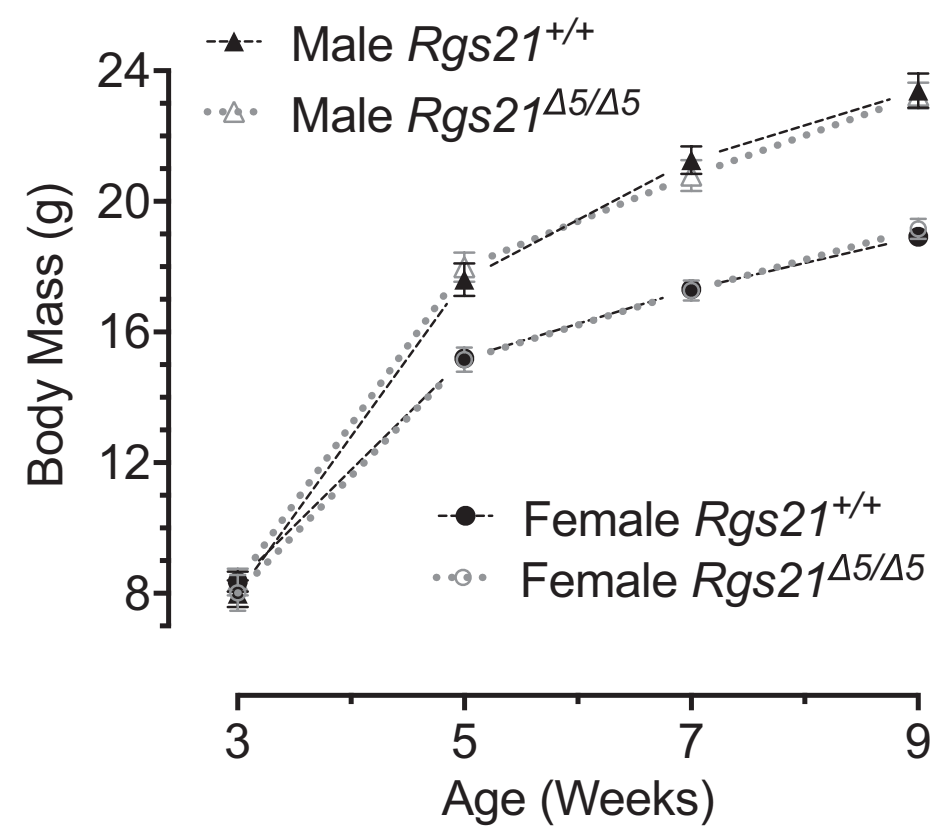

Figure 2.2. Mean \pm SEM body mass of male $(n=10)$ and female $(n=10) R g s 21^{\Delta 5 / \Delta 5}$ mice (and wild-type littermate controls; male $n=9$, female $n=13$ ) at $3,5,7$, and 9 weeks of age. A two-way ANOVA was used to compare the body mass of wild-type and Rgs21-null mice within each sex at the indicated time points. No statistical difference was found in body mass between $R g s 21^{\Delta / / \Delta 5}$ and $R g s 21^{+/+}$female $(p=0.8471)$ or male mice $(p=0.9384)$. 

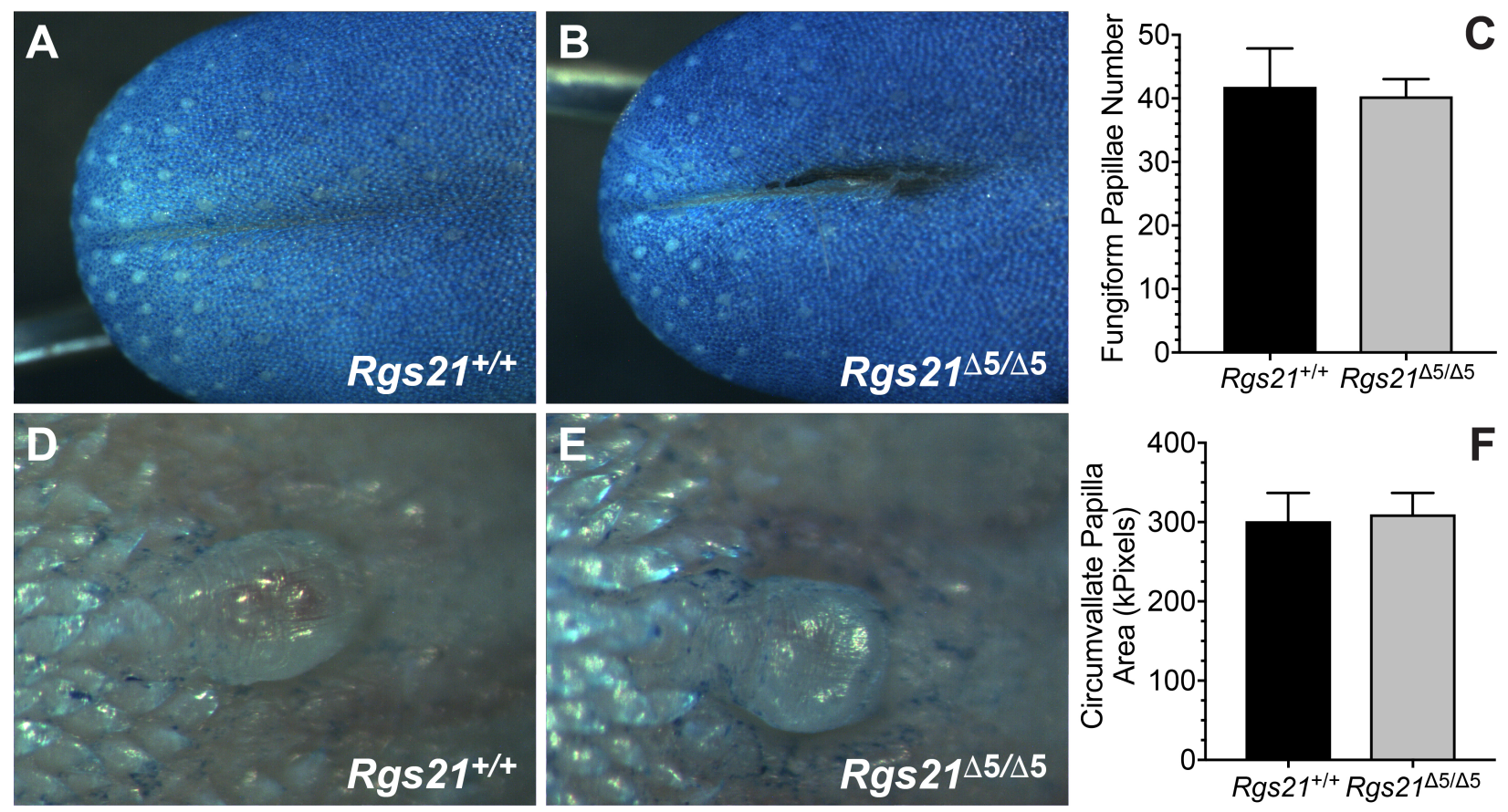

Figure 2.3. Normal tongue morphology in Rgs21-null mice. Tongues of wild-type ( $n=6$;

e.g., panel A) and Rgs2 $1^{\Delta 5 / \Delta 5}$ mice ( $n=6$; e.g., panel B) were stained with methylene blue to visualize the fungiform papillae on the anterior portions. There was no difference found in mean fungiform papillae number or morphology between Rgs21-null and wildtype animals (panel C; unpaired Student's $t$-test; $p=0.8254$ ). Circumvallate papillae of wild-type $(n=4)$ and $R g s 21^{\Delta 5 / \Delta 5}$ mice $(n=4)$ were observed by bright-field microscopy (panels D, E; areas plotted in panel F). There was no difference found in circumvallate papillae area (panel F; unpaired Student's $t$-test; $p=0.8578$ ). 

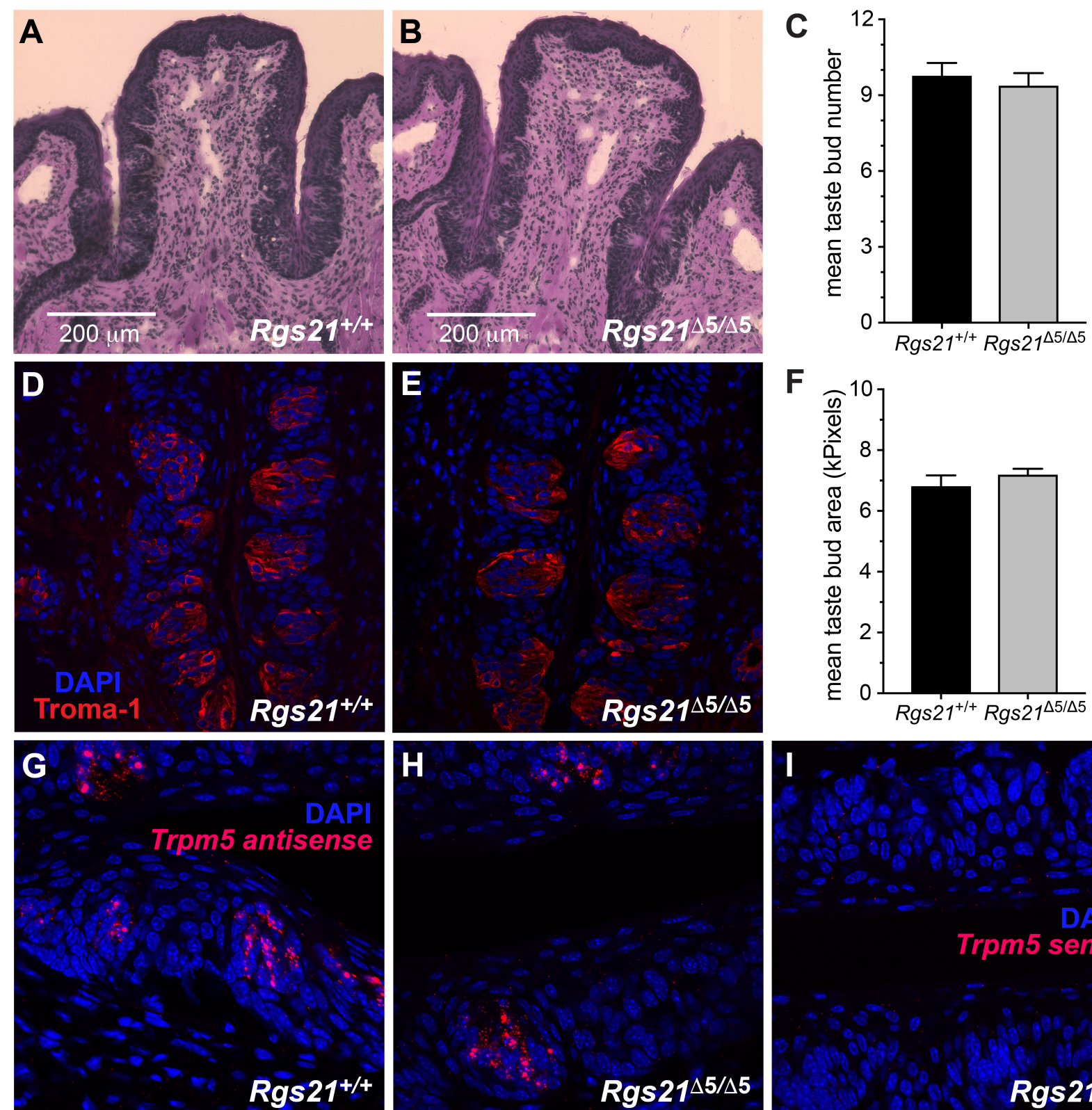

$\operatorname{Rgs}^{21}{ }^{\Delta 5 / \Delta 5}$
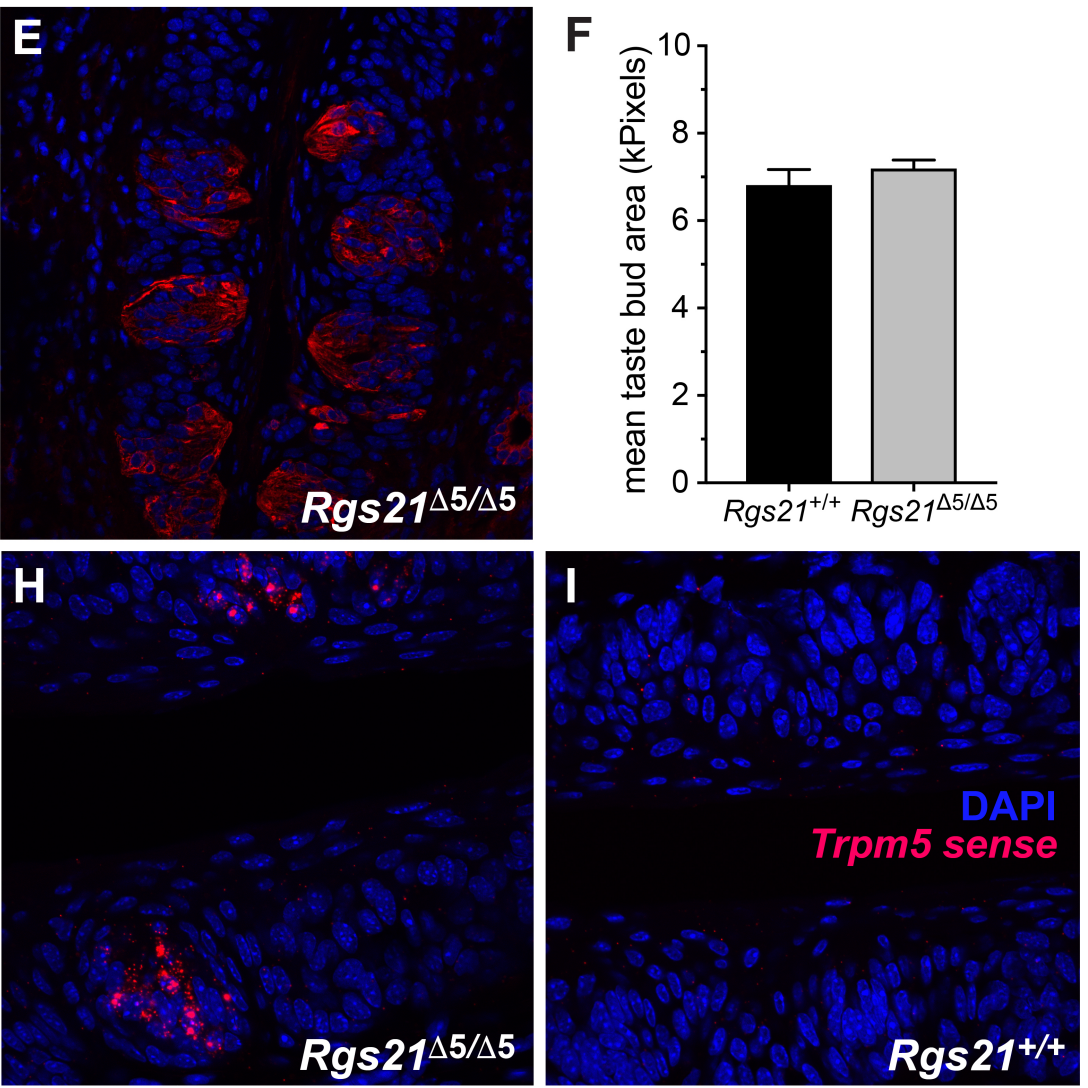

J

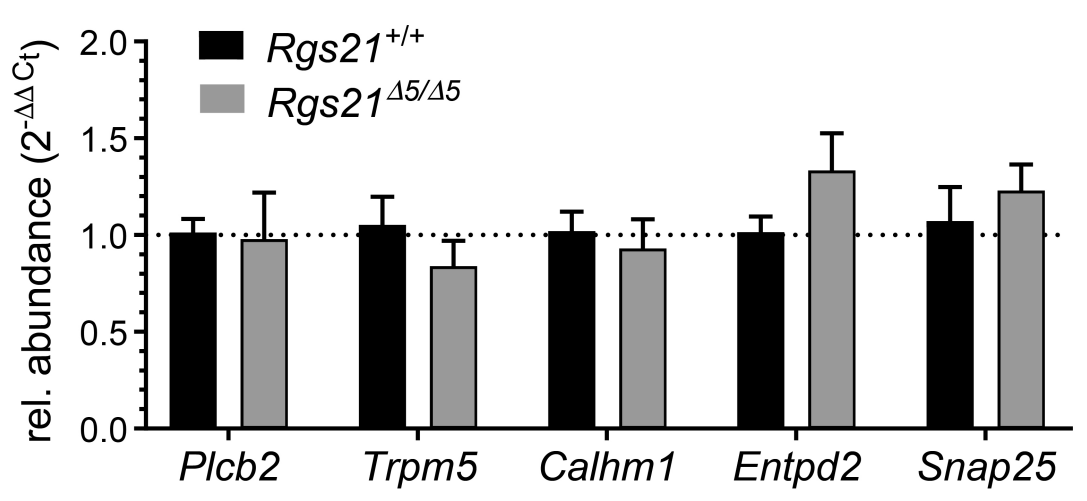


Figure 2.4. Normal morphology and expression of taste cell markers within circumvallate papillae of Rgs21-null mice. To enumerate taste buds, circumvallate papillae of wild-type $(n=4)$ and $R g s 21^{\Delta 5 / \Delta 5}$ mice $(n=4)$ were stained with haematoxylin and eosin (H\&E) (panels A, B), or visualized by dual-color indirect immunofluorescence with the taste cell marker Troma-1 (anti-keratin-8 in red) and DNA dye (DAPI in blue) (panels D-E). There was no difference found in mean taste bud number per section (panel C; unpaired Student's $t$-test; $p=0.5879$ ), or mean taste bud size (panel F; unpaired Student's $t$-test; $p=0.3355$ ) between knockout and wild-type animals. Equivalent detection of the Type II taste cell marker Trpm5 within CV sections was observed in both genotypes via in situ hybridization and subsequent confocal microscopy (panels $\mathrm{G}$ and $\mathrm{H}$ with antisense probe; panel I with control, sense probe). Equivalent mRNA expression was also observed by qRT-PCR for additional markers of Type I (Entpd2), Type II (PIcb2, Trpm5, Calhm1), and Type III (Snap25) taste cells (panel J). Bar-graph displays the mean \pm S.E.M.; differences between genotypes was not statistically significant by Student's $t$-test. 

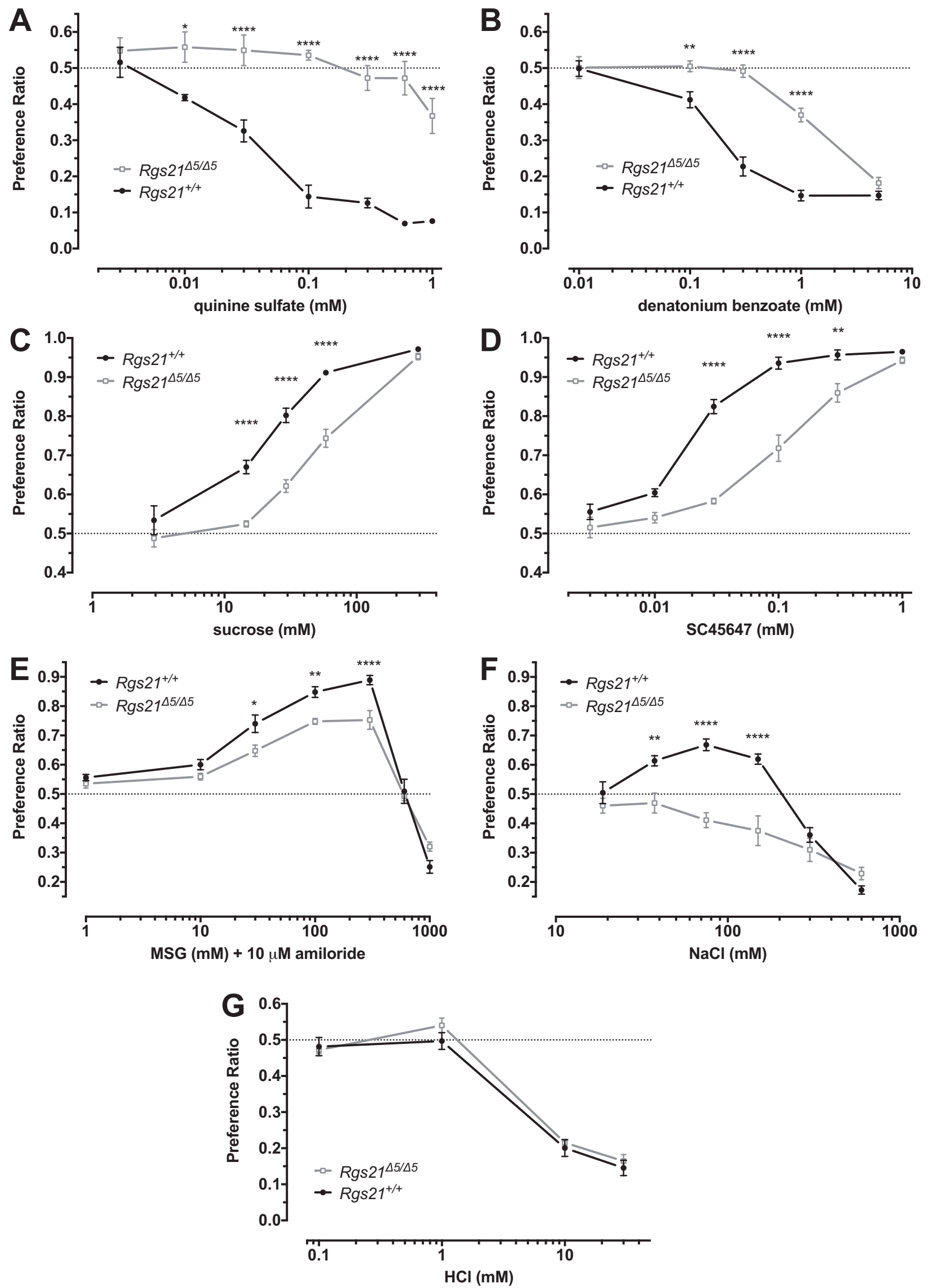
Figure 2.5. Two-bottle choice preferences of $\operatorname{Rgs} 21^{\Delta 5 / \Delta 5}(\mathrm{n}=7)$ and wild-type mice $(\mathrm{n}=$ 7) for ascending concentration series of the bitterants quinine sulfate (panel A), denatonium benzoate (panel $\mathrm{B}$ ), the sour tastant hydrochloric acid (panel C), the sweeteners sucrose (panel D) and SC45647 (panel E) and the L-amino acid umami tastant monosodium glutamate in the presence of $10 \mu \mathrm{M}$ amiloride (panel $\mathrm{F}$ ). Each test was assessed with a two-way ANOVA. Differences between the groups in preference for specific concentrations of taste solution were determined using Sidak post-hoc test to correct for multiple comparisons $\left({ }^{*} p<0.05 ;{ }^{* *} p<0.01 ;{ }^{* * *} p<0.001 ;{ }^{* * *} p<\right.$ $0.0001)$. 

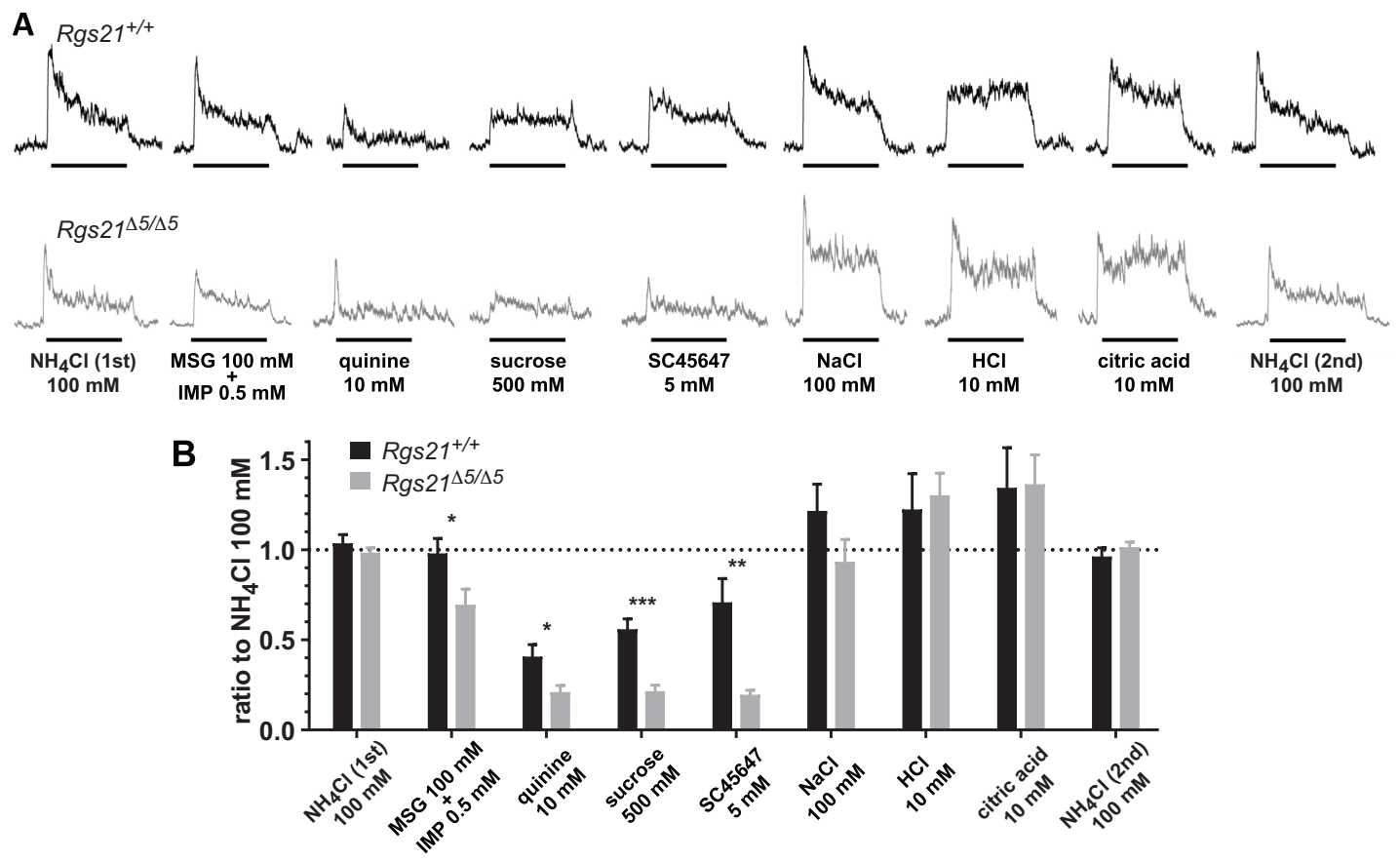

Figure 2.6. (A) Representative integrated chorda tympani nerve responses in $\operatorname{Rgs} 21^{\Delta 5 / \Delta 5}$ mice. Indicated taste stimuli were applied for $30 \mathrm{~s}$ with 40 -s intervening washes. (B) Amplitude of the integrated response for each tastant. Responses were normalized to the responses to $100 \mathrm{mM} \mathrm{NH}_{4} \mathrm{Cl}$, recorded both at the beginning and the end of each tastant series, to control for variability between mice. Responses show the mean \pm SEM ( $n=7-10$ mice for each stimulus). No significant difference was observed between $\mathrm{Rgs} 21^{+/+}$and $\mathrm{Rgs} 21^{\Delta 5 / \Delta 5}$ mice for $\mathrm{NH}_{4} \mathrm{Cl}$ or the sour tastants $\mathrm{HCl}$ and citric acid (unpaired Student's $t$-tests: $p>0.7$ for $\mathrm{NH}_{4} \mathrm{Cl}, p>0.9$ for sour tastants). Decreased responses of $R g s 21^{\Delta 5 / \Delta 5}$ mice to the umami agonists MSG + IMP, the bitterant quinine, and the sweeteners sucrose and SC45647 were statistically significant (unpaired 
Student's $t$-tests: $p<0.03$ for MSG+IMP, $p<0.022$ for quinine, $p<0.0002$ for sucrose, $p<0.002$ for SC45647). A trend toward a decreased response to $100 \mathrm{mM} \mathrm{NaCl}$ was observed in $R g s 21^{\Delta 5 / \Delta 5}$ mice, but the difference was not statistically significant $(p<0.16$; Student's $t$-test). 


\section{7 - References}

Adler E, Hoon MA, Mueller KL, Chandrashekar J, Ryba NJ, Zuker CS. 2000. A novel family of mammalian taste receptors. Cell 100: 693-702.

Angleson JK, Wensel TG. 1993. A GTPase-accelerating factor for transducin, distinct from its effector cGMP phosphodiesterase, in rod outer segment membranes. Neuron 11: 939-949.

Bachmanov AA, Beauchamp GK, Tordoff MG. 2002. Voluntary consumption of $\mathrm{NaCl}$, $\mathrm{KCl}, \mathrm{CaCl} 2$, and $\mathrm{NH} 4 \mathrm{Cl}$ solutions by 28 mouse strains. Behav Genet 32: 445457.

Barnett NP, Apodaca TR, Magill M, Colby SM, Gwaltney C, Rohsenow DJ, Monti PM. 2010. Moderators and mediators of two brief interventions for alcohol in the emergency department. Addiction 105: 452-465.

Berman DM, Wilkie TM, Gilman AG. 1996. GAIP and RGS4 are GTPase-activating proteins for the Gi subfamily of $\mathrm{G}$ protein alpha subunits. Cell $86: 445-452$.

Bo X, Alavi A, Xiang Z, Oglesby I, Ford A, Burnstock G. 1999. Localization of ATPgated $\mathrm{P} 2 \mathrm{X} 2$ and $\mathrm{P} 2 \mathrm{X} 3$ receptor immunoreactive nerves in rat taste buds. Neuroreport 10: 1107-1111.

Bufe B, Hofmann T, Krautwurst D, Raguse JD, Meyerhof W. 2002. The human TAS2R16 receptor mediates bitter taste in response to beta-glucopyranosides. Nat Genet 32: 397-401.

Bystrova MF, Yatzenko YE, Fedorov IV, Rogachevskaja OA, Kolesnikov SS. 2006. P2Y isoforms operative in mouse taste cells. Cell Tissue Res 323: 377-382. 
Chandrashekar J, Mueller KL, Hoon MA, Adler E, Feng L, Guo W, Zuker CS, Ryba NJ. 2000. T2Rs function as bitter taste receptors. Cell 100: 703-711.

Chandrashekar J, Kuhn C, Oka Y, Yarmolinsky DA, Hummler E, Ryba NJ, Zuker CS. 2010. The cells and peripheral representation of sodium taste in mice. Nature 464: 297-301.

Chang RB, Waters H, Liman ER. 2010. A proton current drives action potentials in genetically identified sour taste cells. Proc Natl Acad Sci U S A 107: 2232022325.

Chen CK, Burns ME, He W, Wensel TG, Baylor DA, Simon MI. 2000. Slowed recovery of rod photoresponse in mice lacking the GTPase accelerating protein RGS9-1. Nature 403: 557-560.

Clapp TR, Yang R, Stoick CL, Kinnamon SC, Kinnamon JC. 2004. Morphologic characterization of rat taste receptor cells that express components of the phospholipase C signaling pathway. J Comp Neurol 468: 311-321.

Cohen SP, Buckley BK, Kosloff M, Garland AL, Bosch DE, Cheng G, Radhakrishna H, Brown MD, Willard FS, Arshavsky VY, Tarran R, Siderovski DP, Kimple AJ. 2012. Regulator of G-protein signaling-21 (RGS21) is an inhibitor of bitter gustatory signaling found in lingual and airway epithelia. J Biol Chem 287: 41706-41719.

Damak S, Rong M, Yasumatsu K, Kokrashvili Z, Perez CA, Shigemura N, Yoshida R, Mosinger B, Jr., Glendinning JI, Ninomiya Y, Margolskee RF. 2006. Trpm5 null mice respond to bitter, sweet, and umami compounds. Chem Senses 31: 253264. 
DeFazio RA, Dvoryanchikov G, Maruyama Y, Kim JW, Pereira E, Roper SD, Chaudhari N. 2006. Separate populations of receptor cells and presynaptic cells in mouse taste buds. J Neurosci 26: 3971-3980.

Druey KM, Blumer KJ, Kang VH, Kehrl JH. 1996. Inhibition of G-protein-mediated MAP kinase activation by a new mammalian gene family. Nature 379: 742-746.

Ferkey DM, Hyde R, Haspel G, Dionne HM, Hess HA, Suzuki H, Schafer WR, Koelle MR, Hart AC. 2007. C. elegans G protein regulator RGS-3 controls sensitivity to sensory stimuli. Neuron 53: 39-52.

Finger TE, Danilova V, Barrows J, Bartel DL, Vigers AJ, Stone L, Hellekant G, Kinnamon SC. 2005. ATP signaling is crucial for communication from taste buds to gustatory nerves. Science 310: 1495-1499.

Freedman NJ, Lefkowitz RJ. 1996. Desensitization of G protein-coupled receptors. Recent Prog Horm Res 51: 319-351; discussion 352-313.

He W, Cowan CW, Wensel TG. 1998. RGS9, a GTPase accelerator for phototransduction. Neuron 20: 95-102.

Hisatsune C, Yasumatsu K, Takahashi-Iwanaga H, Ogawa N, Kuroda Y, Yoshida R, Ninomiya Y, Mikoshiba K. 2007. Abnormal taste perception in mice lacking the type 3 inositol 1,4,5-trisphosphate receptor. J Biol Chem 282: 37225-37231.

Hoon MA, Northup JK, Margolskee RF, Ryba NJ. 1995. Functional expression of the taste specific G-protein, alpha-gustducin. Biochem J 309 ( Pt 2): 629-636.

Huang L, Shanker YG, Dubauskaite J, Zheng JZ, Yan W, Rosenzweig S, Spielman AI, Max M, Margolskee RF. 1999. Ggamma13 colocalizes with gustducin in taste 
receptor cells and mediates IP3 responses to bitter denatonium. Nat Neurosci 2: 1055-1062.

Huang YA, Dando R, Roper SD. 2009. Autocrine and paracrine roles for ATP and serotonin in mouse taste buds. J Neurosci 29: 13909-13918.

Huang YA, Stone LM, Pereira E, Yang R, Kinnamon JC, Dvoryanchikov G, Chaudhari N, Finger TE, Kinnamon SC, Roper SD. 2011. Knocking out P2X receptors reduces transmitter secretion in taste buds. J Neurosci 31: 13654-13661.

Kataoka S, Toyono T, Seta Y, Ogura T, Toyoshima K. 2004. Expression of P2Y1 receptors in rat taste buds. Histochem Cell Biol 121: 419-426.

Kimple AJ, Bosch DE, Giguere PM, Siderovski DP. 2011. Regulators of G-protein signaling and their Galpha substrates: promises and challenges in their use as drug discovery targets. Pharmacol Rev 63: 728-749.

Kimple AJ, Garland AL, Cohen SP, Setola V, Willard FS, Zielinski T, Lowery RG, Tarran R, Siderovski DP. 2014. RGS21, a regulator of taste and mucociliary clearance? Laryngoscope 124: E56-63.

Kinnamon SC, Finger TE. 2013. A taste for ATP: neurotransmission in taste buds. Front Cell Neurosci 7: 264.

Koelle MR, Horvitz HR. 1996. EGL-10 regulates G protein signaling in the C. elegans nervous system and shares a conserved domain with many mammalian proteins. Cell 84: 115-125.

Kusakabe Y, Yasuoka A, Asano-Miyoshi M, Iwabuchi K, Matsumoto I, Arai S, Emori Y, Abe K. 2000. Comprehensive study on G protein alpha-subunits in taste bud 
cells, with special reference to the occurrence of Galphai2 as a major Galpha species. Chem Senses 25: 525-531.

Lambert NA, Johnston CA, Cappell SD, Kuravi S, Kimple AJ, Willard FS, Siderovski DP. 2010. Regulators of G-protein signaling accelerate GPCR signaling kinetics and govern sensitivity solely by accelerating GTPase activity. Proc Natl Acad Sci U S A 107: 7066-7071.

Laroche G, Giguère PM, Roth BL, Trejo J, Siderovski DP. 2010. RNA interference screen for RGS protein specificity at muscarinic and protease-activated receptors reveals bidirectional modulation of signaling. Am J Physiol Cell Physiol 299: C654-664.

Li X, Staszewski L, Xu H, Durick K, Zoller M, Adler E. 2002. Human receptors for sweet and umami taste. Proc Natl Acad Sci U S A 99: 4692-4696.

Liebl DJ, Mbiene JP, Parada LF. 1999. NT4/5 mutant mice have deficiency in gustatory papillae and taste bud formation. Dev Biol 213: 378-389.

Luttrell LM, Lefkowitz RJ. 2002. The role of beta-arrestins in the termination and transduction of G-protein-coupled receptor signals. J Cell Sci 115: 455-465.

McLaughlin SK, McKinnon PJ, Margolskee RF. 1992. Gustducin is a taste-cell-specific G protein closely related to the transducins. Nature $357: 563-569$.

Ming D, Ruiz-Avila L, Margolskee RF. 1998. Characterization and solubilization of bitterresponsive receptors that couple to gustducin. Proc Natl Acad Sci U S A 95: 8933-8938.

Nelson G, Hoon MA, Chandrashekar J, Zhang Y, Ryba NJ, Zuker CS. 2001. Mammalian sweet taste receptors. Cell 106: 381-390. 
Nelson G, Chandrashekar J, Hoon MA, Feng L, Zhao G, Ryba NJ, Zuker CS. 2002. An amino-acid taste receptor. Nature 416: 199-202.

North RA. 2002. Molecular physiology of P2X receptors. Physiol Rev 82: 1013-1067.

Oka Y, Butnaru M, von Buchholtz L, Ryba NJ, Zuker CS. 2013. High salt recruits aversive taste pathways. Nature 494: 472-475.

Okubo T, Pevny LH, Hogan BL. 2006. Sox2 is required for development of taste bud sensory cells. Genes Dev 20: 2654-2659.

Palmer RK. 2007. The pharmacology and signaling of bitter, sweet, and umami taste sensing. Mol Interv 7: 87-98.

Rajagopal S, Shenoy SK. 2018. GPCR desensitization: Acute and prolonged phases. Cell Signal 41: 9-16.

Ruiz CJ, Wray K, Delay E, Margolskee RF, Kinnamon SC. 2003. Behavioral evidence for a role of alpha-gustducin in glutamate taste. Chem Senses 28: 573-579.

Sakamoto T, Fujii A, Saito N, Kondo H, Ohuchi A. 2016. Alteration of amiloride-sensitive salt taste nerve responses in aldosterone/ $\mathrm{NaCl}$-induced hypertensive rats. Neurosci Res 108: 60-66.

Seki T, Namba T, Mochizuki H, Onodera M. 2007. Clustering, migration, and neurite formation of neural precursor cells in the adult rat hippocampus. J Comp Neurol 502: $275-290$.

Shindo Y, Miura H, Carninci P, Kawai J, Hayashizaki Y, Ninomiya Y, Hino A, Kanda T, Kusakabe Y. 2008. G alpha14 is a candidate mediator of sweet/umami signal transduction in the posterior region of the mouse tongue. Biochem Biophys Res Commun 376: 504-508. 
Siderovski DP, Hessel A, Chung S, Mak TW, Tyers M. 1996. A new family of regulators of G-protein-coupled receptors? Curr Biol 6: 211-212.

Siderovski DP, Willard FS. 2005. The GAPs, GEFs, and GDIs of heterotrimeric Gprotein alpha subunits. Int J Biol Sci 1: 51-66.

Snow BE, Hall RA, Krumins AM, Brothers GM, Bouchard D, Brothers CA, Chung S, Mangion J, Gilman AG, Lefkowitz RJ, Siderovski DP. 1998. GTPase activating specificity of RGS12 and binding specificity of an alternatively spliced PDZ (PSD95/DIg/ZO-1) domain. J Biol Chem 273: 17749-17755.

Tao GZ, Toivola DM, Zhong B, Michie SA, Resurreccion EZ, Tamai Y, Taketo MM, Omary MB. 2003. Keratin-8 null mice have different gallbladder and liver susceptibility to lithogenic diet-induced injury. J Cell Sci 116: 4629-4638.

Taruno A, Vingtdeux V, Ohmoto M, Ma Z, Dvoryanchikov G, Li A, Adrien L, Zhao H, Leung S, Abernethy M, Koppel J, Davies P, Civan MM, Chaudhari N, Matsumoto I, Hellekant G, Tordoff MG, Marambaud P, Foskett JK. 2013. CALHM1 ion channel mediates purinergic neurotransmission of sweet, bitter and umami tastes. Nature 495: 223-226.

Tizzano M, Dvoryanchikov G, Barrows JK, Kim S, Chaudhari N, Finger TE. 2008. Expression of Galpha14 in sweet-transducing taste cells of the posterior tongue. BMC Neurosci 9: 110.

Toh H, Rittman G, Mackenzie IC. 1993. Keratin expression in taste bud cells of the circumvallate and foliate papillae of adult mice. Epithelial Cell Biol 2: 126-133. 
Tordoff MG, Ellis HT, Aleman TR, Downing A, Marambaud P, Foskett JK, Dana RM, McCaughey SA. 2014. Salty taste deficits in CALHM1 knockout mice. Chem Senses 39: 515-528.

Tu YH, Cooper AJ, Teng B, Chang RB, Artiga DJ, Turner HN, Mulhall EM, Ye W, Smith AD, Liman ER. 2018. An evolutionarily conserved gene family encodes protonselective ion channels. Science.

Vandenbeuch A, Clapp TR, Kinnamon SC. 2008. Amiloride-sensitive channels in type I fungiform taste cells in mouse. BMC Neurosci 9: 1.

Vandenbeuch A, Anderson CB, Parnes J, Enjyoji K, Robson SC, Finger TE, Kinnamon SC. 2013. Role of the ectonucleotidase NTPDase2 in taste bud function. Proc Natl Acad Sci U S A 110: 14789-14794.

Vandenbeuch A, Anderson CB, Kinnamon SC. 2015a. Mice Lacking Pannexin 1 Release ATP and Respond Normally to All Taste Qualities. Chem Senses 40: 461-467.

Vandenbeuch A, Larson ED, Anderson CB, Smith SA, Ford AP, Finger TE, Kinnamon SC. 2015b. Postsynaptic P2X3-containing receptors in gustatory nerve fibres mediate responses to all taste qualities in mice. J Physiol 593: 1113-1125.

von Buchholtz L, Elischer A, Tareilus E, Gouka R, Kaiser C, Breer H, Conzelmann S. 2004. RGS21 is a novel regulator of G protein signalling selectively expressed in subpopulations of taste bud cells. Eur J Neurosci 19: 1535-1544.

Watson N, Linder ME, Druey KM, Kehrl JH, Blumer KJ. 1996. RGS family members: GTPase-activating proteins for heterotrimeric G-protein alpha-subunits. Nature 383: $172-175$. 
Wong GT, Gannon KS, Margolskee RF. 1996. Transduction of bitter and sweet taste by gustducin. Nature 381: 796-800.

Woodard GE, Jardin I, Berna-Erro A, Salido GM, Rosado JA. 2015. Regulators of Gprotein-signaling proteins: negative modulators of G-protein-coupled receptor signaling. Int Rev Cell Mol Biol 317: 97-183.

Yaylaoglu MB, Titmus A, Visel A, Alvarez-Bolado G, Thaller C, Eichele G. 2005. Comprehensive expression atlas of fibroblast growth factors and their receptors generated by a novel robotic in situ hybridization platform. Dev Dyn 234: 371 386.

Ye W, Chang RB, Bushman JD, Tu YH, Mulhall EM, Wilson CE, Cooper AJ, Chick WS, Hill-Eubanks DC, Nelson MT, Kinnamon SC, Liman ER. 2016. The K+ channel KIR2.1 functions in tandem with proton influx to mediate sour taste transduction. Proc Natl Acad Sci U S A 113: E229-238.

Zhang C, Cotter M, Lawton A, Oakley B, Wong L, Zeng Q. 1995. Keratin 18 is associated with a subset of older taste cells in the rat. Differentiation 59: 155162.

Zhang Y, Hoon MA, Chandrashekar J, Mueller KL, Cook B, Wu D, Zuker CS, Ryba NJ. 2003. Coding of sweet, bitter, and umami tastes: different receptor cells sharing similar signaling pathways. Cell 112: 293-301.

Zhao GQ, Zhang Y, Hoon MA, Chandrashekar J, Erlenbach I, Ryba NJ, Zuker CS. 2003. The receptors for mammalian sweet and umami taste. Cell 115: 255-266. 


\title{
Chapter 3
}

\section{Further investigations of RGS21 in taste physiology}

\author{
Adam B. Schroer ${ }^{1}$, Joshua D. Gross ${ }^{1}$, Shane W. Kaski ${ }^{1}$, Kim Wix ${ }^{1}$, \\ David P. Siderovski ${ }^{1}$, Vincent Setola ${ }^{1,2, *}$
}

\begin{abstract}
${ }^{1}$ Department of Physiology, Pharmacology, and Neuroscience, West Virginia School of Medicine, One Medical Center Drive, Morgantown, WV 26506, USA, ${ }^{2}$ Department of Behavioral Medicine and Psychiatry, West Virginia School of Medicine, 930 Chestnut Ridge Road, Morgantown, WV 26505, USA
\end{abstract}




\section{1 - Abstract}

Taste is a chemical sense that enables communication with the environment, promoting ingestion of nutrients and aversion toward toxic substances. Canonically, there are five taste modalities: bitter, sweet, savory (umami), salty, and sour. Traditionally, only bitter, sweet, and umami taste are mediated by G protein-coupled receptors (GPCRs) that transduce signals via modulation of heterotrimeric $\mathrm{G}$ protein signaling. Recently, we identified reduced GPCR-mediated taste responsiveness in mice lacking the GTPase-accelerating protein (GAP) Regulator of G protein Signaling21 (RGS21). This reduction in responsivity was also observed for salt taste, a modality traditionally associated with ion channel activity, but more recently thought to also engage GPCR signaling. RGS21 reduces second messenger production in tasteresponsive cells in vitro; therefore, it was hypothesized that RGS21-deficient mice should have increased taste responsiveness. Reduced tastant-mediated responses and behaviors exhibited by adult mice lacking Rgs 21 expression since birth have thus revealed an underappreciated requirement for a GPCR GAP to establish the full character of tastant signaling. How lack of RGS21 shapes the responsiveness of taste cells is unknown; therefore, we further sought to investigate Rgs21 deficiency in mouse taste responsiveness to better understand its role in peripheral taste signaling.

Key words: Gustatory, mouse, regulator of G protein signaling-21 (RGS21), taste buds, taste perception 


\section{2 - Introduction}

Three taste modalities, sweet, bitter, and umami ("savory"), are transduced by G protein-coupled receptors (GPCRs) in chemosensory cells of the oral cavity. Sour taste responses are not mediated by GPCR signaling, but by entry of protons through a $\mathrm{Zn}^{2+}-$ sensitive proton conductance (Chang et al., 2010), recently identified as OTOP1 (Tu et al., 2018). Entry of protons into taste cells block the inwardly rectifying $\mathrm{K}^{+}$channel, KIR2.1, resulting in membrane depolarization (Ye et al., 2016). Sweet and umami tastes are mediated by the T1R GPCRs (Montmayeur et al., 2001; Nelson et al., 2001, 2002; Li et al., 2002a; Zhao et al., 2003), while bitter tastes are detected by a family of $\sim 30$ GPCRs, the T2Rs (Adler et al., 2000; Chandrashekar et al., 2000; Bufe et al., 2002). GPCR-mediated tastant signaling is primarily transduced by $\mathrm{G} \alpha$ nucleotide exchange and release of the G $\beta \gamma$ dimer (McLaughlin et al., 1992; Wong et al., 1996; Ming et al., 1998; Huang et al., 1999; Kusakabe et al., 2000; Shindo et al., 2008), which in turn activates PLC $\beta 2$, calcium release and, subsequently, activation of the TRPM5 channel (Zhang et al., 2003). Opening of TRPM5 channels triggers membrane depolarization and extracellular release of ATP through the CALHM1 ion channel (Finger et al., 2005; Taruno et al., 2013), which in turn activates ATP-gated, ionotropic P2X2 and P2X3 receptors on gustatory afferent nerve fibers (Bo et al., 1999; Eddy et al., 2009; Kinnamon and Finger, 2013; Vandenbeuch et al., 2015a, 2015b) and also, in an autocrine manner, the metabotropic purinergic and adenosine receptors on Type II taste cells themselves (Kataoka et al., 2004, 2012; Bystrova et al., 2006; Huang et al., 2009; Dando et al., 2012). 
Regulators of $G$ protein signaling (RGS) proteins like RGS21 accelerate inactivation of GPCR-activated G $\alpha$ subunits (Berman et al., 1996; Watson et al., 1996; Snow et al., 1998; Cohen et al., 2012; Kimple et al., 2014). RGS21 was first identified as a novel RGS protein selectively expressed in PLC 32 -positive Type II taste receptor cells (von Buchholtz et al., 2004; Cohen et al., 2012; Kimple et al., 2014); therefore, the loss of Rgs21 is expected to potentiate signaling by agonist-occupied GPCRs (Lambert et al., 2010; Kimple et al., 2011), such as the tastant-responsive T1Rs and T2Rs of Type II cells (Adler et al., 2000; Chandrashekar et al., 2000; Montmayeur et al., 2001; Nelson et al., 2001, 2002; Bufe et al., 2002; Li et al., 2002b; Zhao et al., 2003) and/or the purinergic $\mathrm{P} 2 \mathrm{Y}$ receptors and adenosine A2B receptors thought to support Type II cell signaling via extracellular ATP/ADP/adenosine-mediated potentiation of further ATP release (Kataoka et al., 2004, 2012; Bystrova et al., 2006; Huang et al., 2009; Dando et al., 2012; Kinnamon and Finger, 2013). In either case, GPCR-targeting tastants should be more potent upon Rgs21 loss; therefore, the reduced responsiveness of Rgs21deficient mice to sweet, umami, and bitter taste stimuli we previously discovered was unexpected (Schroer et al., 2018). We have now performed additional experimentation in an attempt to better understand the role of RGS21 in modulating taste signaling. 


\section{3 - Materials \& Methods}

\subsection{1 - Subjects and maintenance}

All experiments involved either Rgs21 wild-type, constitutive knockout, constitutive heterozygous, and/or conditional knockout mice. Rgs21 'floxed' (Rgs2 $1^{f / f l}$ ) mice were produced at genOway (Lyon, France), as previously described (Schroer et al., 2018). This $R g s 21^{\mathrm{fl} / f l}$ strain was maintained at WVU by backcrossing to the C57BL/6J strain. The procedure for generating the constitutive Rgs21-null mice used in this study was described previously (Schroer et al., 2018). Briefly, the $R g s 21^{\mathrm{flffl}}$ mice were crossed with an ubiquitous Cre recombinase driver strain [B6.C- $\mathrm{Tg}(\mathrm{CMV}$ cre)1Cgn/J; JAX 006054] to excise exon 5 of the Rgs2 $1^{\text {fl/fl }}$ mice to generate $R g s 21^{\Delta 5 /+}$ (Rgs21-heterozygous) mice. These $R g s 21^{\Delta 5 /+}$ mice were bred together to generate Rgs21 $1^{\Delta 5 / \Delta 5}$ mice (i.e., Rgs21-null) mice, Rgs21 ${ }^{\Delta 5 /+}$ (Rgs21-heterozygous) mice, and $R g s 21^{+/+}$(i.e., wild-type) littermate control mice. Genotyping was performed via PCR using ear-snip tissue-derived genomic DNA and the following primer pairs: Shared Rgs21 allele forward primer 5'-CTGCCTTTGGGAAGCTTATG-3' (nts. 144520871 144520890 of GenBank NC_000067.6 [C57BL/6J chromosome 1]) with either wild-type Rgs21 allele reverse primer 5'-TGGTATGGTGGTGGTGTTGT-3' (nts. 144520654 144520673 of NC_000067.6) or with $R g s 21^{\Delta 5 /+}$ allele reverse primer 5' CATTTCAGGGTTTGGAAAAGTT-3' (nts. 144519608 - 144519629 of NC_000067.6).

Conditional Rgs21-null mice were produced by crossing the $R g s 21^{\mathrm{fl/fl}}$ mice with the tamoxifen (TM)-inducible Cre recombinase driver strain CAGGCre-ER ${ }^{T M}[B 6 . \mathrm{Cg}$ $\mathrm{Tg}\left(\mathrm{CAG}-\mathrm{cre} / \mathrm{Esr} 1^{*}\right) 5 \mathrm{Amc} / \mathrm{J}$; JAX 004682]. The CAGGCre-ER ${ }^{\mathrm{TM}}$ transgenic mouse strain provides a tamoxifen (TM)-inducible Cre-mediated recombination system driven by a hybrid chicken $\beta$-actin/cytomegalovirus promoter/enhancer element (Hayashi and 
McMahon, 2002). This allele was kept in the heterozygous condition, as transgenehomozygous mice are not viable, but heterozygous CAGGCre-ER ${ }^{\mathrm{TM}}$ mice are viable, fertile, normal in size, and have no gross physical or behavioral abnormalities (Hayashi and McMahon, 2002). Rgs21 $1^{\text {fl/fl; }}$ CAGGCre-ER ${ }^{\mathrm{TM}}$ mice were intraperitoneal (IP) injected with $75 \mathrm{mg} / \mathrm{kg}$ of tamoxifen (dissolved in corn oil) for five consecutive days, then we waited seven days prior to experimentation (Sohal et al., 2001; Madisen et al., 2010). As controls, littermate Rgs2 $1^{\text {fl/flif }}$ CAGGCre-ER ${ }^{T M}$ mice were sham-injected for five days with corn oil (vehicle) and kept for an additional seven days.

Mice used in this study were maintained in a vivarium at $23{ }^{\circ} \mathrm{C}$ on a $12 \mathrm{~h} / 12 \mathrm{~h}$ light/dark cycle with lights off at 6 PM. They were housed in Allentown mouse cages $(194 \times 181 \times 398 \mathrm{~mm})$ with wire bar lids and corncob bedding, along with crinkled paper scattered on the floor for environmental enrichment. The mice had ad libitum access to Teklad Global 18\% Protein Rodent Diet (Envigo, Inc.) and water (except during exposure tests, see below). Pups were weaned at 21 days and initially housed in groups of the same sex. All mice were at least 8 weeks old prior to subsequent animal testing. All procedures were approved by the Institutional Animal Care and Use Committee of the West Virginia University Health Sciences Center.

\subsection{2 - RNA extraction}

Tongues were excised from mice euthanized with Fatal-Plus $₫$ in accordance with guidelines from the National Institute of Health and with approval from the West Virginia University IACUC. Tongues were homogenized in TRIzol reagent (Invitrogen ${ }^{\mathrm{TM}}$ ) using a bench top rotor stator. RNA was extracted according to manufacturer's instructions using the Direct-zol ${ }^{\mathrm{TM}}$ RNA MiniPrep kit from Zymo Research. Reverse transcription 
and genomic DNA elimination was performed using the QuantiTect Reverse Transcription Kit from Qiagen.

\subsection{3 - Real-time quantitative reverse transcription-polymerase chain reaction (qRT-PCR)}

qRT-PCR was performed to compare the expression levels of $18 \mathrm{~S}$ rRNA and Rgs21 mRNA in Rgs21-deficient mice and Rgs21+/+ littermate controls. RNA extraction was performed as above. Two microliters of cDNA were used in each PCR reaction using the QuantiTect SYBR Green PCR Master Mix (Qiagen). RT² qPCR Primer Assay for Mouse 18S rRNA was purchased from Qiagen. Primers $(10 \mu \mathrm{M})$ were designed for Rgs21 mRNA (spanning exons 4-5) sequence elements (fwd primer: 5'TCGTAGCTGATGCACCAAAA-3'; rev primer 5'-TACAGGAAAGGCAGCCATCT-3') and

purchased from ThermoFisher Scientific. PCR was performed (initial 15 min denaturation at $95^{\circ} \mathrm{C}$ followed by 40 cycles of $15 \mathrm{~s}$ denaturation at $95^{\circ} \mathrm{C}, 30 \mathrm{~s}$ annealing at $60^{\circ} \mathrm{C}$, and 30 s extension at $72^{\circ} \mathrm{C}$ ) in a Qiagen Rotor Gene-Q system. We utilized the SYBR green dye qPCR technique to detect double-stranded PCR amplicons as they accumulated during PCR cycling. Melting curves were obtained after each qRT-PCR experiment to assure specificity of resultant amplicons.

\subsection{4 - Brief-access taste test}

Brief-access taste tests (Stellar and Hill, 1952; Houpt and Frankmann, 1996) were conducted in a Davis Rig Brief Access Lickometer (16-bottle capacity "legacy version"; Med Associates) as described previously (Glendinning et al., 2002). Prior to all training (i.e., lickometer acclimation) sessions, mice were water deprived for $22.5 \mathrm{~h}$ to 
promote drinking. All animals underwent three days of training (spout and shutter acclimation) to become accustomed to drinking from the Davis rig prior to testing. During the initial spout acclimation, the mouse was placed in the Davis rig, and the session lasted for 30 min once the mouse took its first lick. On the following two days of training (shutter acclimation), the mouse was given access to the drinking tube with the shutter door open until $5 \mathrm{~s}$ after it took its first lick. The door remained closed for $7.5 \mathrm{~s}$ before re-opening with a different drinking tube revealed. The mouse was allowed to initiate as many trials as possible during the 30 min training session (and all subsequent test sessions).

Following training and prior to test sessions with quinine, mice were water deprived for $22.5 \mathrm{~h}$ to enhance drinking behavior. Following each 30 -min testing session mice were allowed to rehydrate with ad libitum access to water for $1 \mathrm{~h}$. To enhance drinking behavior towards sucrose (which requires less thirst motivation than aversive stimuli), mice were restricted to $1 \mathrm{~g}$ of chow and $2 \mathrm{~mL}$ of water for $22.5 \mathrm{~h}$ prior to each test session and allowed one recovery day (ad libitum food and water) following each session. Taste solutions were presented in multiple blocks with a randomized order of concentration for the duration of each 30 min session (Quinine $-0.01,0.03,0.1,0.3,1.0$ $\mathrm{mM}$; Sucrose $-30,100,300,1000 \mathrm{mM})$. During each quinine test session the tastant/water lick ratio was calculated and averaged across the three test sessions. The sucrose data are reported as ratio of licks/total licks to account for motivational differences between mice (i.e., in the event no solution was preferred the ratio would be 0.2 from random licking from all 5 concentrations provided). Two-way repeated measures ANOVAs were used to test for significant effects of genotype on the lick ratio. 
Table 3.1: Brief-access timetable of phenotyping for quinine aversion

$\begin{array}{lll}\text { Day } & \text { Activity } & \text { Food/water access on prior day } \\ 1 & \text { water deprivation } & \text { food/water ad libitum } \\ 2 & \text { spout acclimation } & 22.5 \mathrm{~h} \text { water deprivation } \\ 3,4 & \text { shutter acclimation } & 22.5 \mathrm{~h} \text { water deprivation } \\ 5,6,7 & \text { quinine } & 22.5 \mathrm{~h} \text { water deprivation }\end{array}$

Table 3.2: Brief-access timetable of phenotyping for sucrose preference

$\begin{array}{lll}\frac{\text { Day }}{1} & \text { Activity } & \text { Food/water access on prior day } \\ 2 & \text { water deprivation } & \text { food/water ad libitum } \\ 3 & \text { spout acclimation } & 22.5 \mathrm{~h} \text { water deprivation } \\ 4 & \text { shutter acclimation } & 22.5 \mathrm{~h} \text { water deprivation } \\ 5,7,9 & \text { shutter acclimation } & 22.5 \mathrm{~h} \text { water deprivation } \\ 6,8,10 & \text { recovery day } & \text { food } / \text { water ad libitum } \\ & \text { sucrose } & 1 \mathrm{~g} \mathrm{chow} / 2 \mathrm{ml} \text { water in } 22.5 \mathrm{~h}\end{array}$

\subsection{5 - Two-bottle choice tests}

Two-bottle choice tests were conducted as described previously (Schroer et al., 2018). Briefly, mice were individually housed in large Thoren mouse cages $(30.80 \mathrm{~cm} x$ $40.60 \mathrm{~cm} \times 15.88 \mathrm{~cm}$ ). Mice were given access to two bottles containing autoclaved distilled water for $48 \mathrm{~h}$ prior to beginning all choice testing. Fluid was available through sipper spouts attached to $50-\mathrm{mL}$ Corning ${ }^{\mathrm{TM}}$ conical-bottom centrifuge tubes, placed in separate bottle access slots on opposite sides of the food bin. Following the initial 48-h presentation of two bottles of water, mice were assessed over $48 \mathrm{~h}$ in tests with a choice between distilled water and ascending concentrations of a taste compound. The positions of the bottles were switched daily, and the fluid intakes were measured to the nearest $0.1 \mathrm{~g}$ by weighing the drinking bottles on an electronic balance. Preference ratio was calculated as volume of tastant solution consumed divided by volume of total solution consumed. The taste compounds were chosen to assess salty and bitter taste stimuli: Quinine Sulfate - 0.003, 0.01, 0.03, 0.1, 0.3, and $1 \mathrm{mM} ; \mathrm{NaCl}-30,65,100,300$, 
and $600 \mathrm{mM} ; \mathrm{KCl}-30,65,100,200,400$, and $600 \mathrm{mM}$. The mice used in salt taste testing were assessed with $\mathrm{NaCl}$ followed by $\mathrm{KCl}$. Mice were socially housed for 7 days between each test series. At least 6 mice per genotype were assessed at each concentration of taste solution. Results were analyzed using a two-way ANOVA (genotype $\times$ concentration) with a Sidak multiple comparisons test (GraphPad Prism 7).

\subsection{6 - NaCl taste threshold recognition test}

Following exposure to lithium chloride $(\mathrm{LiCl})$ in their drinking water, which causes mice to become temporarily ill and tastes similar to $\mathrm{NaCl}$, mice will avoid $\mathrm{NaCl}$. This allows the determination of the lowest concentration of $\mathrm{NaCl}$ that tastes salty to mice. $\mathrm{NaCl}$ recognition threshold tests were performed as described previously (Ishiwatari and Bachmanov, 2009, 2012). Briefly, individually housed wild-type and Rgs21-deficient mice will be given a choice between two bottles of water for $48 \mathrm{~h}$ to familiarize them with access to two drinking spouts. To condition mice to avoid all salty solutions, mice were exposed to $\mathrm{LiCl}$ in their drinking water: two bottles of $150 \mathrm{mM} \mathrm{LiCl}$ for $24 \mathrm{~h}$, two bottles of water for $24 \mathrm{~h}$ to allow recovery, and then a second exposure to two bottles of 150 $\mathrm{mM} \mathrm{LiCl}$ for $24 \mathrm{~h}$. After a second 48-h recovery period with two bottles of water, mice underwent 48-h tests with a choice between water and an ascending series of $\mathrm{NaCl}$ $(0.25,0.5,1,2,4,8,16,32,64$, and $150 \mathrm{mM} \mathrm{NaCl})$ as performed in two bottle choice testing detailed above. Results were analyzed using a two-way ANOVA (genotype $\times$ concentration) with a Sidak multiple comparisons test (GraphPad Prism 7). The lowest concentration that mice begin to avoid $\mathrm{NaCl}$ is an indicator of the lowest concentration of $\mathrm{NaCl}$ that they can detect (Ishiwatari and Bachmanov, 2009, 2012). 


\subsection{7 - Additional Rgs genes in taste receptor cells}

Rgs genes differentially expressed in Tas $1 r 3+$ taste cells versus Type III taste cells were identified by RNA-Seq transcriptomic analyses. Data were extracted from recently published transcriptomics profiles of fluorescently-identified Tas1r3-GFP cells ( $n=9)$ and physiologically-identified Type III taste cells ( $n=17)$ (Sukumaran et al., 2017) (NCBI accession SRP094673). 


\section{4 - Results \& Discussion}

\subsection{1 - Taste-salient brief-access assays of bitterant avoidance and sweetener preference}

GPCR-mediated taste responses are influenced by RGS21 (Schroer et al., 2018), but, to confirm that loss of RGS21 causes a deficit in peripheral taste signaling we performed brief-access taste tests. As an organism's preference for particular compounds is heavily influenced by stimulatory post-oral signals (Zukerman et al., 2011), this specific behavioral assay minimizes the influence of certain post-oral factors (e.g., satiety, toxicity) in the assessment of behavioral taste responses of Rgs21deficient mice.

$R g s 21^{+/+}$mice revealed the expected aversion to the bitterant quinine beginning at the $0.03 \mathrm{mM}$ concentration; similar to prior findings in two-bottle choice assays (Schroer et al., 2018), Rgs2 ${ }^{\Delta 5 / \Delta 5}$ mice were indifferent to all concentrations of quinine except $1.0 \mathrm{mM}$, and even then were only minimally avoidant (Figure 3.1A). Additionally, $\operatorname{Rgs} 21^{\Delta 5 / \Delta 5}$ mice showed significantly less avidity towards the sweetener sucrose than

wild-type littermates (Figure 3.1B). These findings validate the loss of GPCR-mediated taste responses in Rgs21-deficient mice, further confirming that the latter phenotypes do not necessarily involve post-ingestive tastant effects (Zukerman et al., 2011).

[Location for Figure 3.1]

\subsection{2 - Gene-dose effect of Rgs21 deficiency}

RGS21 appears to influence GPCR-mediated taste responses (Schroer et al., 2018); but how are these responses regulated by an RGS protein's GAP activity, which 
opposes GPCR signaling? We suspect that RGS21 loss leads to hyperactivity of tastant GPCRs and/or one or more taste-promoting regulatory GPCRs (e.g. P2YR1/R2, adenosine $\mathrm{A} 2 \mathrm{~B}$ receptor), eventually causing their prolonged desensitization and/or downregulation (Garzón et al., 2001; Ferkey et al., 2007; Hwang et al., 2015). Thus, a reduction of RGS21, rather than complete removal of its expression, would delay GPCR inactivation, but maintain a minimum level of regulation, thereby preventing desensitization and/or downregulation. "Gene dosing" can occur with loss of one allele of a gene (e.g., Rgs21-heterozygous mice) resulting in a reduced amount of gene product (Yao et al., 1998); however, this reduction of gene product is gene-dependent. Therefore, we performed two-bottle choice testing with heterozygous Rgs21-deficient mice $\left(\operatorname{Rgs} 21^{+/ \Delta 5}\right)$, as any gene dosage effect afforded by heterozygosity would serve as a better model for partial loss-of-function mutations likely to be seen in humans (e.g., SNPs rs77664911, rs142678159 in human RGS21 gene).

In two-bottle choice assays, $\operatorname{Rgs} 21^{+/ \Delta 5}$ heterozygous mice showed normal aversion to quinine (Figure 3.2A) and a normal inverted $\mathrm{U}$-shaped function for $\mathrm{NaCl}$ (i.e., appetitive response at moderate doses, but aversion at higher concentrations) (Figure 3.2B), while Rgs2 $1^{\Delta 5 / \Delta 5}$ mice showed a lack of aversion to quinine and no appetitive response to $\mathrm{NaCl}$. Additionally, Rgs21 mRNA transcript abundance was absent in $R g s 21^{\Delta 5 / \Delta 5}$ mice, but $R g s 21^{+/ \Delta 5}$ heterozygous mice displayed expression equivalent to that of wild-type controls (Figure 3.2C). Thus, the Rgs21 allele does not appear to produce a gene dosage effect when "knocked out" by homologous recombination; thus, we do not yet know whether partial loss-of-function or modulation of RGS21 levels results in a different taste response phenotype (e.g., increased 
responsiveness to GPCR-mediated tastants) than what has been established in our prior study of the constitutive Rgs21-knockout mouse (Schroer et al., 2018).

[Location for Figure 3.2]

\subsection{3 - Taste responsiveness phenotyping after acute RGS21 loss}

Acute Rgs21 knockdown in tastant-responsive bronchial epithelial cells leads to amplified second messenger levels upon exposure to the bitterant denatonium (Cohen et al., 2012), suggesting that RGS21 functions as a conventional GAP in curtailing G protein-dependent taste signaling. In contrast, mice constitutively lacking RGS21 expression (i.e., from zygote formation to adult stage) have reduced responsiveness to GPCR-mediated taste stimuli (Schroer et al., 2018), suggesting a possible difference between an acute loss of RGS21 function and a prolonged absence of RGS21 expression. To better understand the role of RGS21 in taste signaling, we therefore sought to determine the impact of removing RGS21 expression in lingual tissue after its development by using tamoxifen-mediated excision of Rgs21 in adulthood.

To determine whether RGS21 is acting as an 'acute' player in GPCR-mediated taste transduction, we treated $R g s 21^{\text {fl/flil:CAGGCre-ER }}{ }^{\mathrm{TM}}$ mice with injections of vehicle (corn oil) or $75 \mathrm{mg} / \mathrm{kg}$ of tamoxifen (dissolved in corn oil) for five days, to generate littermate control and 'acute' RGS21-deficient mice (Sohal et al., 2001; Madisen et al., 2010). Real-time quantitative RT-PCR was used to confirm that Rgs21 mRNA expression is observable in the lingual tissue of sham-treated mice, but absent in tamoxifen-treated mice (Figure 3.3 inset). In our studies, acute, tamoxifen-induced Rgs21 excision led to a far less pronounced deficit in quinine aversion than with 
constitutive Rgs21-null mice (Figures 3.3 vs 3.2A). Although knockdown of RGS21 in taste-responsive, immortalized human bronchial epithelial cells caused an increase in bitter stimuli-induced second messenger production (Cohen et al., 2012), the intracellular effect of RGS21 knockdown was not assessed in isolated taste receptor cells per se. Thus, in tamoxifen-induced Rgs21 knockout mice, an acute loss of RGS21 did not directly cause loss of taste responsiveness; rather, a more prolonged period of RGS21 deficiency is necessary. Loss of RGS proteins, and their conventional GAP activity on $\mathrm{G} \alpha$ proteins, typically leads to a prolonged cellular response to GPCRtargeted ligands (He et al., 1998; Chen et al., 2000; Nishiguchi et al., 2004; Sambi et al., 2006; Lambert et al., 2010). However, removal of some RGS proteins, or their ability to interact with $\mathrm{G}_{\alpha}$ proteins, has also been observed to lead to a reduction in cellular responsiveness to certain ligands (Garzón et al., 2001; Ferkey et al., 2007; Hwang et al., 2015). Loss of RGS proteins in certain signaling pathways may cause an increase in receptor phosphorylation and desensitization (Woolf and Linderman, 2003), suggesting that constitutive Rgs21-null mice may undergo a prolonged period of taste receptor desensitization, which could lead to eventual downregulation (Freedman and Lefkowitz, 1996; Tsao and von Zastrow, 2000; Rajagopal and Shenoy, 2018). Therefore, the less pronounced loss of taste responsiveness following tamoxifen-induced excision of Rgs21 may be the result of less receptor downregulation at this acute time point.

[Location for Figure 3.3] 


\subsection{4 - Understanding salt taste deficits in Rgs21-deficient mice}

Multiple pathways mediate salt taste responses, each with concentration-specific roles. The appetitive salt pathway is thought to be selectively responsive to sodium and can be inhibited by amiloride (Heck et al., 1984; Brand et al., 1985; DeSimone and Ferrell, 1985; Chandrashekar et al., 2010). Amiloride is an inhibitor of the epithelial $\mathrm{Na}^{+}$ channel $(\mathrm{ENaC})$; thus, the appetitive response to salt is likely mediated by $\mathrm{ENaC}$, which is expressed in a subpopulation of taste cells, independent of Type II and III taste cells (Vandenbeuch et al., 2008; Chandrashekar et al., 2010; Roper, 2015). The aversive salt taste response is often referred to as amiloride-insensitive, as this pathway is a nonselective detector for a wide range of salts (Duncan, 1962; Heck et al., 1984; Halpern, 1998; Lindemann, 2001; Eylam and Spector, 2005). Recently, it was suggested that amiloride-insensitive salt taste is transduced by high salt concentrations co-opting sourand bitter-responsive cells to stimulate aversive pathways (Oka et al., 2013; Lewandowski et al., 2016), implicating G protein signaling within Type II cells in the aversive response to high salt concentrations (Oka et al., 2013). Additionally, GPCR signaling in Type II cells may be important in the appetitive response to salts (Damak et al., 2006; Hisatsune et al., 2007; Tordoff et al., 2014; Schroer et al., 2018). However, evidence of GPCR signaling in Type II taste cells mediating the attractive response to moderate $\mathrm{NaCl}$ concentrations has been inconsistent (Wong et al., 1996; Zhang et al., 2003). RGS21 is a GAP for heterotrimeric G protein signaling (Cohen et al., 2012; Kimple et al., 2014), which is selectively expressed in PIc $\beta 2$-positive Type II taste receptor cells (von Buchholtz et al., 2004; Cohen et al., 2012; Kimple et al., 2014). RGS21-deficient mice lack an appetitive response to moderate concentrations of salts 
(Schroer et al., 2018), suggesting heterotrimeric G protein signaling in Type II taste receptor cells may mediate a portion of the appetitive salt taste response. Given that multiple mechanisms have been suggested to serve a role in salt taste, each with overlapping, concentration-specific roles, it is difficult to tease out the role of a particular pathway with a single assay. Therefore, we have employed multiple techniques to stitch together a fuller picture of salt taste in $R g s 21^{\Delta 5 / \Delta 5}$ mice.

$\mathrm{LiCl}$ exposure causes mice to become temporarily ill and tastes similar to $\mathrm{NaCl}$; therefore, following exposure to $150 \mathrm{mM} \mathrm{LiCl}$ in their drinking water, mice will avoid $\mathrm{NaCl}$. This allows the determination of the lowest concentration of $\mathrm{NaCl}$ that tastes salty to mice. Rgs21-deficient and wild-type mice drank similar volumes of $\mathrm{LiCl}$ during the training period (Figure 3.4 inset); both groups of mice drank significantly less $\mathrm{LiCl}$ on the second day of exposure, suggesting a learned aversion to $\mathrm{LiCl}$. The $\mathrm{NaCl}$ recognition threshold was not altered in $R g s 21^{\Delta 5 / \Delta 5}$ mice (Figure 3.4), indicating that RGS21 does not modulate the response to low concentrations of $\mathrm{NaCl}$. Similarly, mice deficient in other components of the Type II taste cell G protein signaling pathway (i.e., CALHM1; (Tordoff et al., 2014)) do not exhibit an altered $\mathrm{NaCl}$ recognition threshold. Thus, the $\mathrm{G}$ protein signaling pathway(s) in Type II cells probably does not mediate the response to low concentrations of $\mathrm{NaCl}$.

[Location for Figure 3.4]

To determine whether the altered $\mathrm{NaCl}$ taste responses of RGS21-null mice are due to a $\mathrm{Na}^{+}$-specific taste mechanism (i.e., amiloride-sensitive), we assessed twobottle choice preferences for $\mathrm{NaCl}$ and for the non- $\mathrm{Na}^{+}$salt $\mathrm{KCl}$. Wild-type mice 
preferred moderate concentrations of both $\mathrm{NaCl}$ and $\mathrm{KCl}$ in two-bottle choice tests (Figure 3.5); in contrast, Rgs21-deficient mice did not show preference towards any salt concentration. These findings suggest that the altered salt appetite in $\operatorname{Rgs} 21^{\Delta 5 / \Delta 5}$ mice is likely not specific to $\mathrm{Na}^{+}$taste.

[Location for Figure 3.5]

\subsection{5 - Additional Rgs genes in taste receptor cells}

There are likely additional novel regulators of tastant signaling and novel modes of tastant-germane $\mathrm{G}$ protein signaling to discover by studying the role(s) of RGS proteins in tastant-responsive cells. Our hypothesis is that other RGS proteins, beyond RGS21, also function to selectively affect peripheral taste sensitivity. There are 37 different types of RGS proteins in the human genome (Siderovski and Willard, 2005). Members of the RGS protein superfamily have diverse ancillary functional domains (Siderovski and Willard, 2005), which can allow specific receptor targeting and additional roles for these proteins in modulating signal transduction (Hu and Wensel, 2002; Willard et al., 2007). Therefore, discovering alternative RGS proteins in taste receptor cells may identify alternative functions for this family of proteins within taste transduction.

Recent RNA-Seq data contrasting the transcriptomes of Tas1r3+ taste cells vs Type III taste cells (Sukumaran et al., 2017) revealed pronounced expression of Rgs7, Rgs8, and Rgs12 in Tas1r3+ cells and prominent expression of Rgs2 in Type III taste cells (Figure 3.6). Therefore, the possibility that additional RGS proteins may modulate peripheral taste signaling exists. Furthermore, as these RGS proteins have vastly 
different functional domains aside from their shared, central RGS domain (Figure 4.3) (Siderovski and Willard, 2005; Willard et al., 2007; Anderson et al., 2009), it is possible that they serve divergent roles in peripheral taste responses, warranting further investigation.

[Location of Figure 3.6]

\section{5 - Conclusions}

These investigations have confirmed that RGS21 influences GPCR-mediated taste responses (Schroer et al., 2018) and have provided new evidence, albeit incomplete, for how RGS21 influences taste signaling. Acute loss of RGS21 following tamoxifen-induced Rgs21 excision did not result in as severe a loss of aversion to quinine as seen in constitutive Rgs21-null mice. We suspect that RGS21 loss initially leads to hyperactivity of GPCRs in Type II taste receptor cells, eventually causing their desensitization and/or downregulation (Garzón et al., 2001; Ferkey et al., 2007; Hwang et al., 2015). It is possible that a more prolonged period of desensitization of overactive taste GPCRs in tamoxifen-treated Rgs21-deficient mice is required to produce the downregulation and severe loss of taste responsiveness as found in constitutive $\operatorname{Rgs} 21^{\Delta 5 / \Delta 5}$ mice. Further work is needed to validate that GPCRs in Type II taste cells undergo downregulation in the prolonged absence of RGS21.

We have also confirmed that $R g s 21^{\Delta 5 / \Delta 5}$ mice have less of an appetitive drive for salts than wild-type mice. RGS21 was first identified as a novel RGS protein selectively expressed in PLC $\beta 2$-positive Type II taste receptor cells (von Buchholtz et al., 2004; Cohen et al., 2012; Kimple et al., 2014); therefore, any alteration in taste response in 
$\operatorname{Rgs} 21^{\Delta 5 / \Delta 5}$ mice is likely to be a result of altered peripheral taste signaling. The salt taste mediated by RGS21 does not appear to be $\mathrm{Na}^{+}$selective, as the potassium appetite found in wild-type mice was also found lacking in $\operatorname{Rgs} 21^{\Delta 5 / \Delta 5}$ mice. Further work is needed to determine how RGS21, and likely G protein signaling in Type II taste receptor cells, modulates the appetitive response to various salts.

\section{Funding}

This work was supported, in part, by the West Virginia University E.J. Van Liere Medicine Professorship and William W. Fleming Pharmacology Trust endowments [to D.P.S. and A.B.S., respectively]. 


\section{6 - Figures}
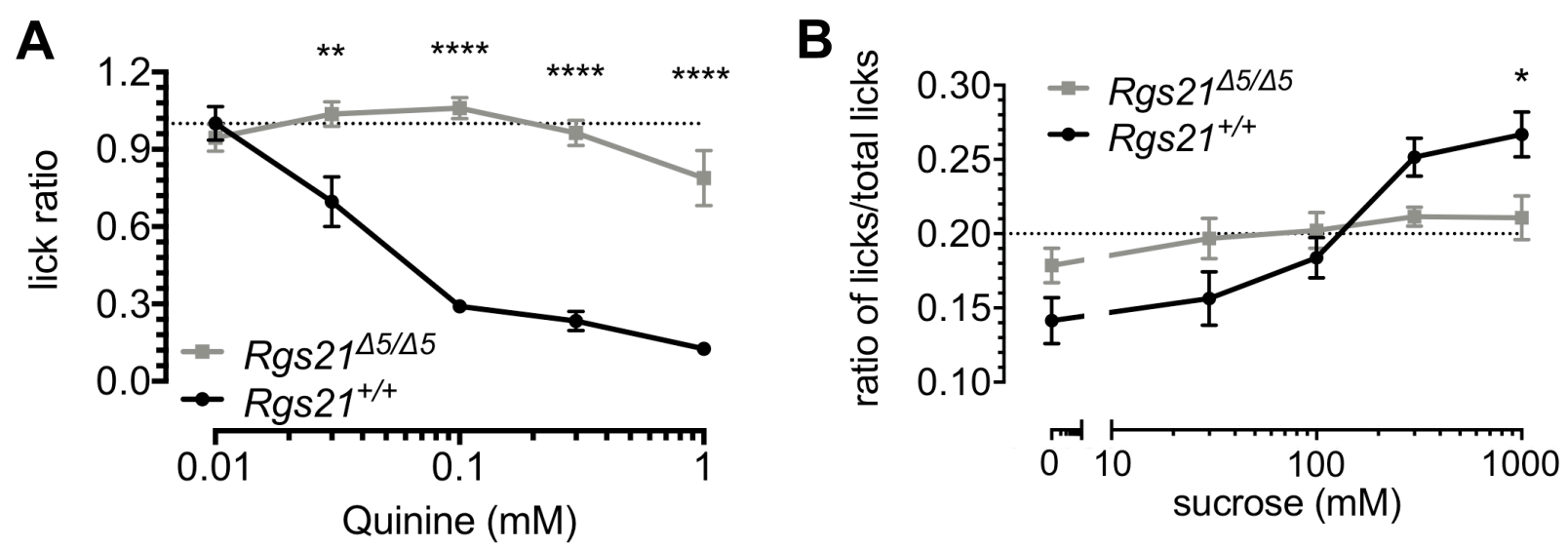

Figure 3.1. Brief-access taste tests using $\operatorname{Rgs} 21^{\Delta 5 / \Delta 5}$ mice and wild-type littermates with indicated concentrations of the bitterant quinine sulfate (panel A) and the sweetener sucrose (panel B). $\operatorname{Rgs} 21^{\Delta 5 / \Delta 5}$ mice displayed reduced behavioral responsivity to both compounds in the taste salient, short-term assays, in agreement with two-bottle choice tests performed previously (Schroer et al., 2018). Brief access sucrose data are reported as ratio of licks/total licks to account for motivational differences between mice (i.e., the horizontal dashed line represents the expected value of the ratio [0.2] from random licking from all 5 concentrations provided). Each test was assessed with a twoway ANOVA. Differences between the groups at specific concentrations of taste solution were determined using Sidak post-hoc test to correct for multiple comparisons $\left({ }^{*} p<0.05 ;{ }^{* *} p<0.01 ;{ }^{* * *} p<0.0001\right)$. 
A

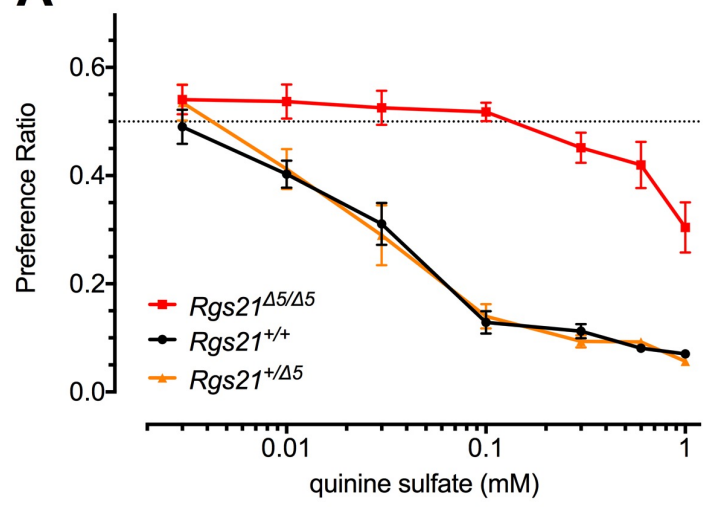

B

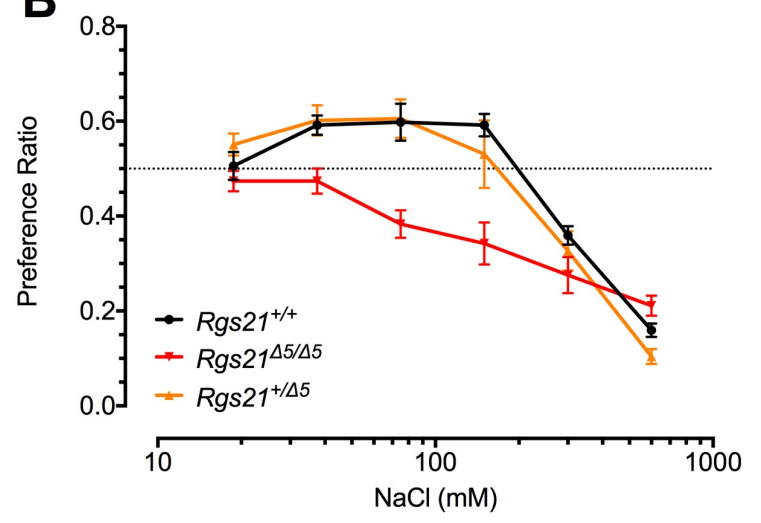

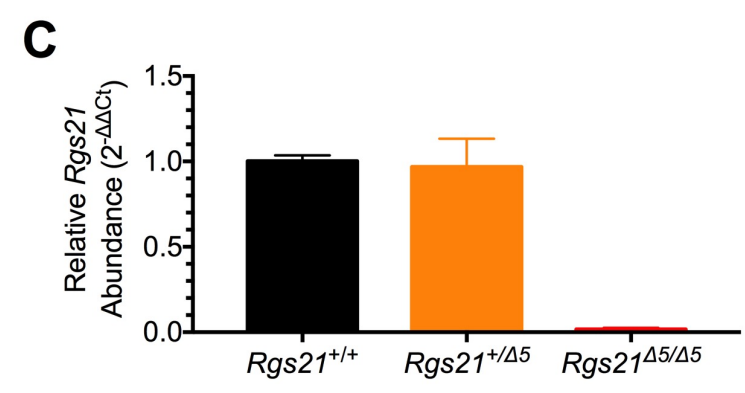

Figure 3.2. Two-bottle choice preferences of Rgs21-heterozygous mice appear normal. $\operatorname{Rgs} 21^{\Delta 5 / \Delta 5}, \operatorname{Rgs} 21^{+/ \Delta 5}$, and wild-type mice ( $\mathrm{n}=6-10$ mice/genotype) were tested for two-bottle choice for ascending concentration series of the bitterant quinine sulfate (panel A) and the salt $\mathrm{NaCl}$ (panel B). Each test was assessed with a two-way ANOVA. A preference ratio of 0.5 (dashed line) indicates indifference towards the taste solution relative to water. Differences between the groups in preference of specific concentrations of taste solution were determined using Sidak post-hoc test to correct for multiple comparisons. Wild-type and $\operatorname{Rgs} 21^{+/ \Delta 5}$ mice appeared to have no difference in preference at any concentration tested. (C) Data from qRT-PCR (SYBR Green detection) of the Rgs21 mRNA transcript, which is seen to be completely absent in $\operatorname{Rgs} 21^{\Delta 5 / \Delta 5}$ mice, but equally detected in tongue from both $R g s 21^{+/+}$and $\operatorname{Rgs} 21^{+/ \Delta 5}$ mice. 


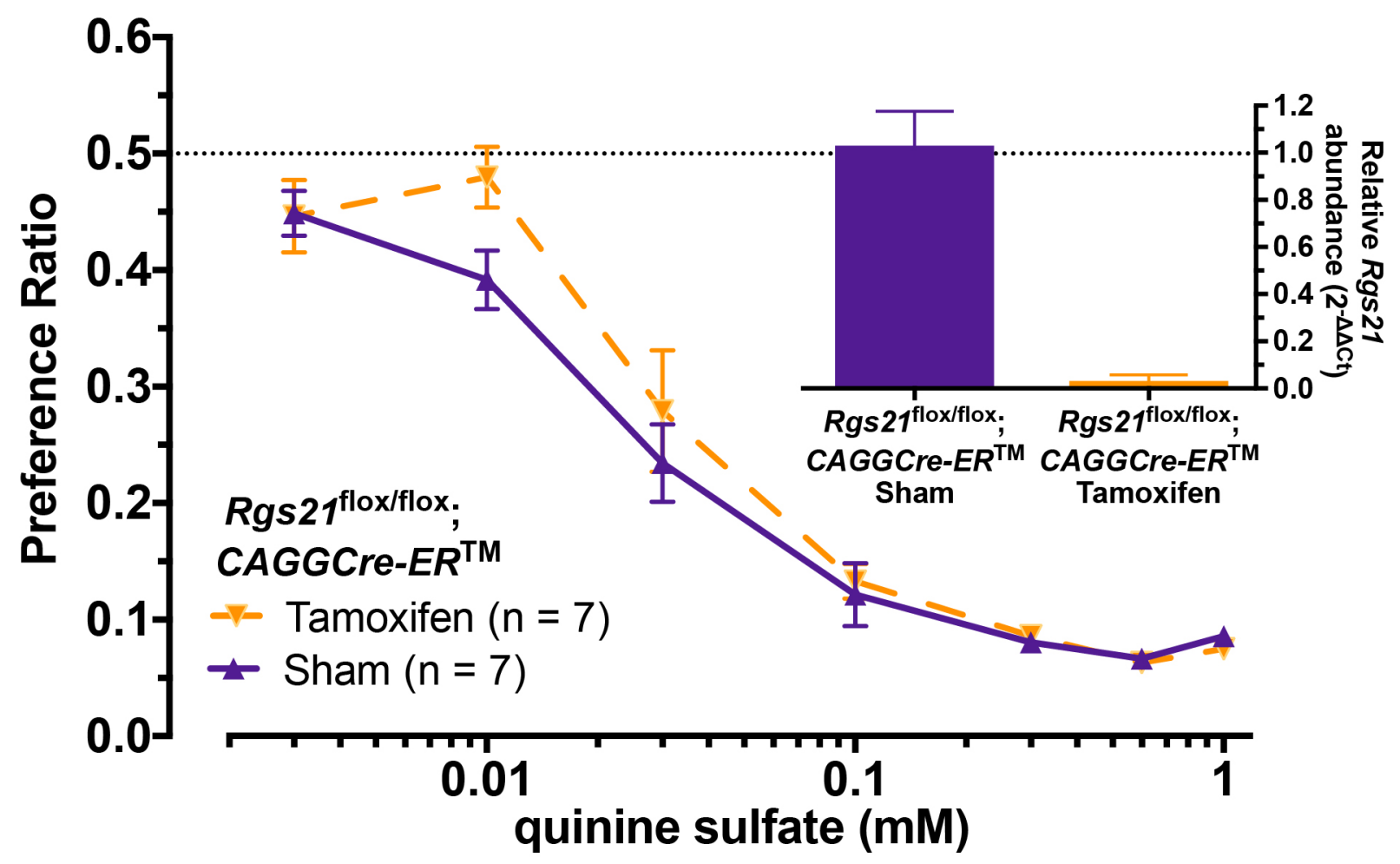

Figure 3.3. Two-bottle choice data suggesting that acute, tamoxifen-induced Rgs 21 excision leads to a far less pronounced deficit in quinine aversion. 8-week old mice were either sham injected (corn oil only) or injected with $75 \mathrm{mg} / \mathrm{kg}$ of tamoxifen dissolved in corn oil once a day for 5 consecutive days. Seven days after final injection and two-bottle testing, tongues were excised and RNA was isolated for qPCR analysis (inset bar-graph). A preference ratio of 0.5 (dashed line) indicates indifference towards the taste solution relative to water. 


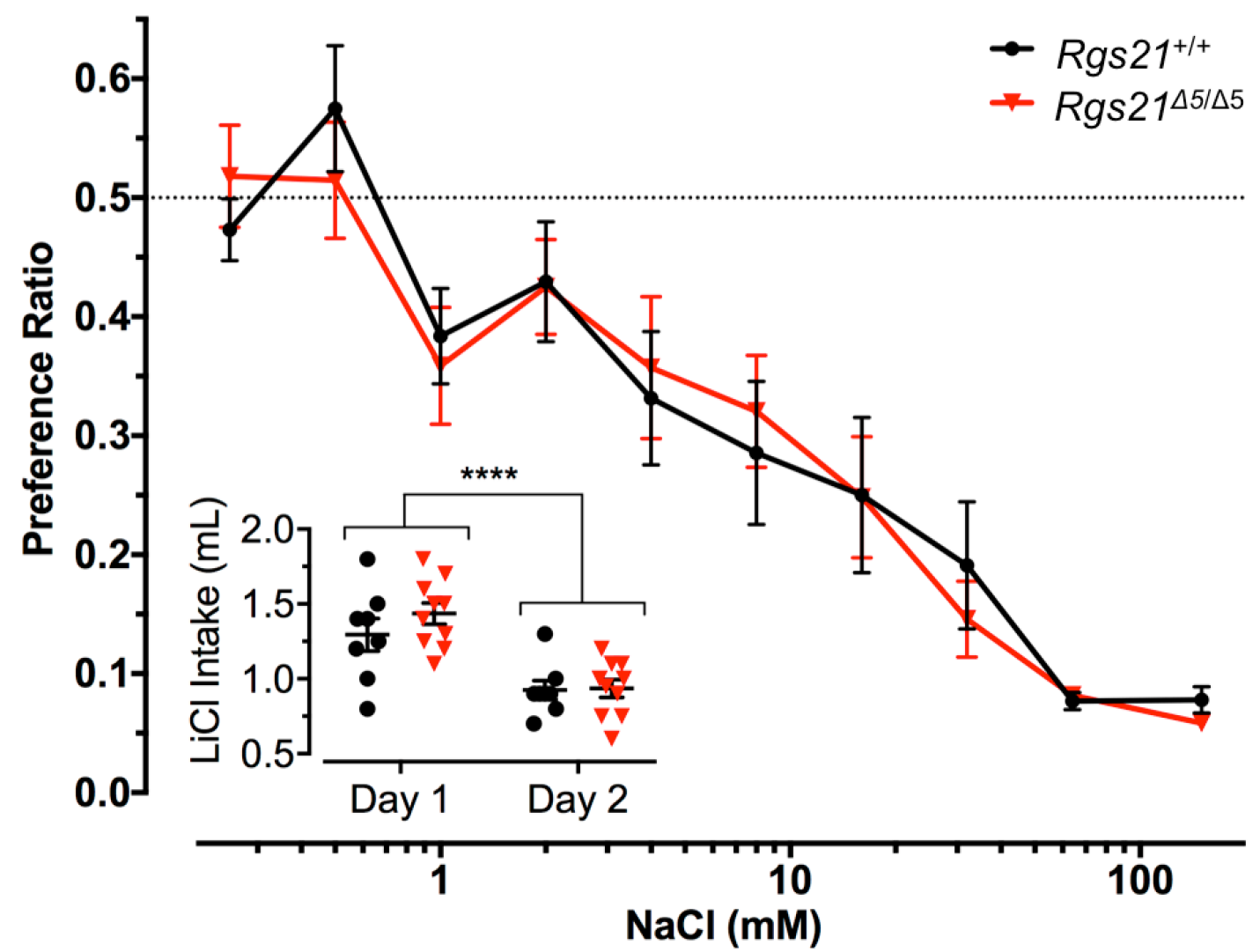

Figure 3.4. Following exposure to $\mathrm{LiCl}$ in their drinking water, which causes mice to become temporarily ill and tastes similar to $\mathrm{NaCl}$, mice will avoid $\mathrm{NaCl}$. This allows the determination of the lowest concentration of $\mathrm{NaCl}$ that tastes salty to mice. Mice were given two bottles containing $150 \mathrm{mM} \mathrm{LiCl}$ for $24 \mathrm{~h}$ (intake shown in inset), a $24-\mathrm{h}$ recovery period with water, then another $24-\mathrm{h}$ period with two bottles containing $150 \mathrm{mM}$ $\mathrm{LiCl}$ (intake shown in inset). Mice drank significantly less $\mathrm{LiCl}$ on the second day of exposure (paired students T test; $\mathrm{p}<0.0001$ ), indicating a learned aversion to $\mathrm{LiCl}$. The mice received $48 \mathrm{~h}$ tests with a choice between water and an ascending series of $\mathrm{NaCl}$ concentrations, as performed in two bottle preference testing. A preference ratio of 0.5 (dashed line) indicates indifference towards the taste solution relative to water. WT and Rgs21-null mice avoided $\mathrm{NaCl}$ similarly with no significant difference between the groups at any concentration. 

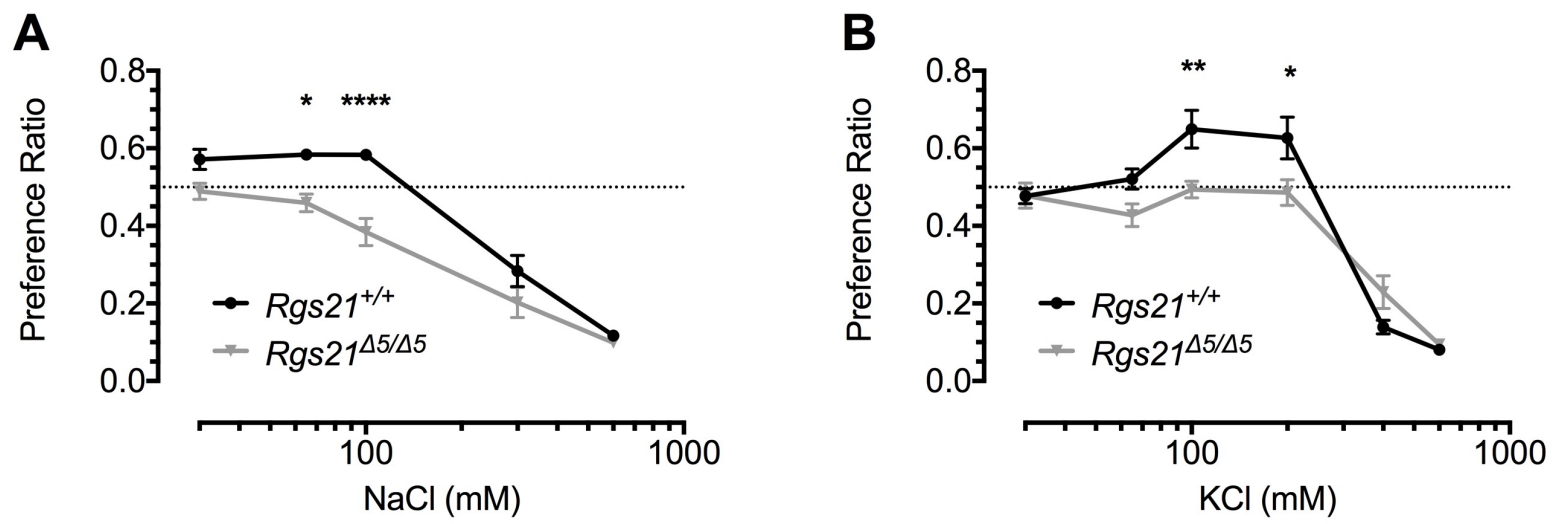

Figure 3.5. Two-bottle choice preferences of $\operatorname{Rgs} 21^{\Delta 5 / \Delta 5}(n=7)$ and wild-type mice $(n=7)$ for ascending concentration series of the salt taste stimuli sodium chloride (panel A) and potassium chloride (panel B). A preference ratio of 0.5 (dashed line) indicates indifference towards the taste solution relative to water. Each test was assessed with a two-way ANOVA. Differences between the groups in preference for specific concentrations of taste solution were determined using Sidak post-hoc test to correct for multiple comparisons $\left({ }^{*} p<0.05 ;{ }^{* *} p<0.01 ;{ }^{* * *} p<0.0001\right)$. 


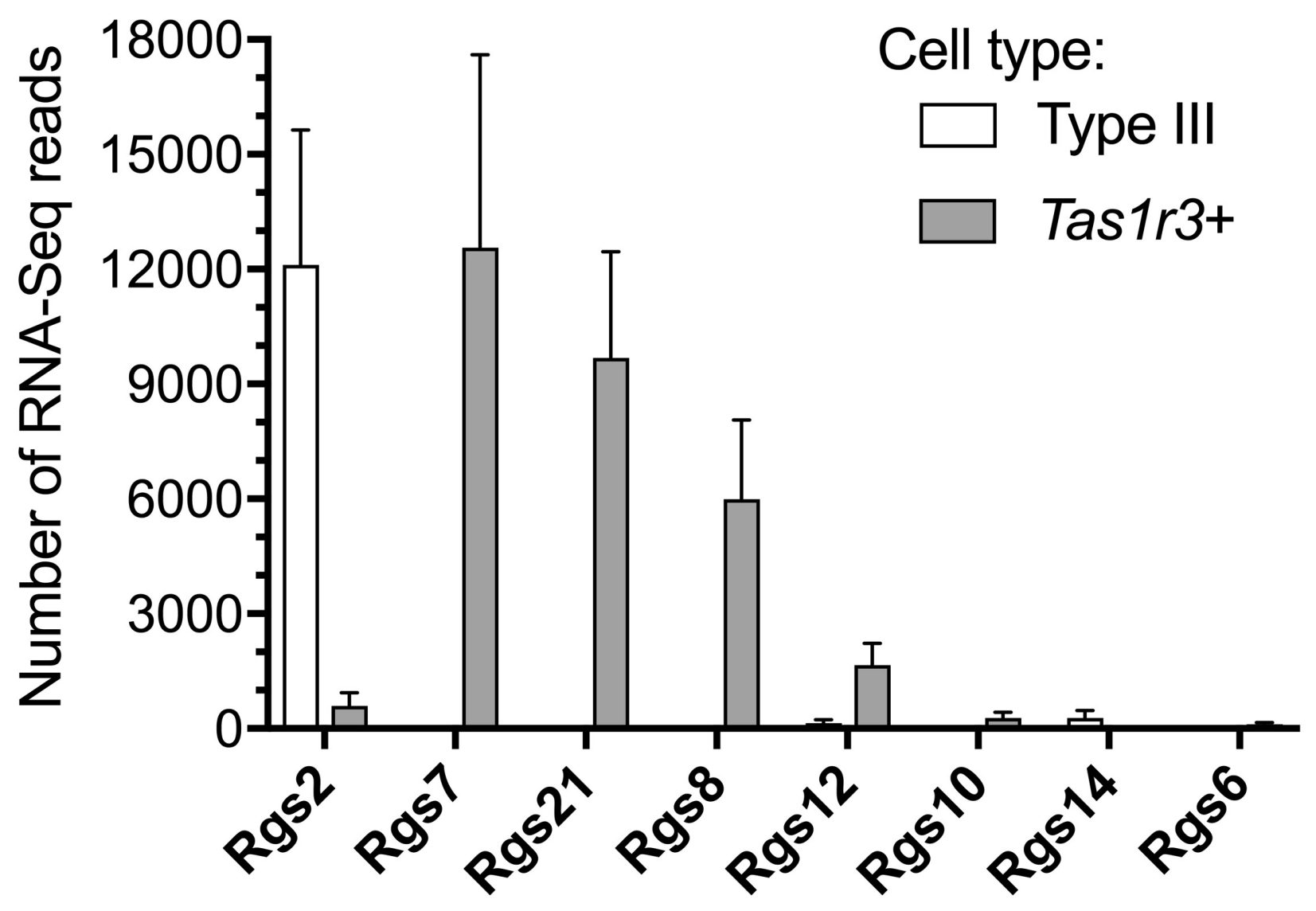

Figure 3.6. Rgs genes differentially expressed in Tas1r3+ taste cells versus Type III taste cells as identified by RNA-Seq transcriptomic analyses. Note the marked differential expression of Rgs7, Rgs21, Rgs8, and Rgs12 in $T a s 1 r 3^{+}$cells. Extracted from transcriptomics data recently published by the Margolskee group (Sukumaran et al., 2017) (NCBI accession SRP094673). 


\section{7 - References}

Adler E, Hoon MA, Mueller KL, Chandrashekar J, Ryba NJ, Zuker CS (2000) A novel family of mammalian taste receptors. Cell 100:693-702.

Anderson GR, Posokhova E, Martemyanov KA (2009) The R7 RGS Protein Family: Multi-Subunit Regulators of Neuronal G Protein Signaling. Cell Biochem Biophys $54: 33-46$.

Berman DM, Wilkie TM, Gilman AG (1996) GAIP and RGS4 Are GTPase-Activating Proteins for the Gi Subfamily of G Protein a Subunits. Cell 86:445-452.

Bo X, Alavi A, Xiang Z, Oglesby I, Ford A, Burnstock G (1999) Localization of ATPgated P2X2 and P2X3 receptor immunoreactive nerves in rat taste buds. Neuroreport 10:1107-1111.

Brand JG, Teeter JH, Silver WL (1985) Inhibition by amiloride of chorda tympani responses evoked by monovalent salts. Brain Res 334:207-214.

Bufe B, Hofmann T, Krautwurst D, Raguse J-D, Meyerhof W (2002) The human TAS2R16 receptor mediates bitter taste in response to $\beta$-glucopyranosides. Nat Genet 32:397-401.

Bystrova MF, Yatzenko YE, Fedorov I V., Rogachevskaja OA, Kolesnikov SS (2006) P2Y isoforms operative in mouse taste cells. Cell Tissue Res 323:377-382.

Chandrashekar J, Kuhn C, Oka Y, Yarmolinsky DA, Hummler E, Ryba NJP, Zuker CS (2010) The cells and peripheral representation of sodium taste in mice. Nature 464:297-301.

Chandrashekar J, Mueller KL, Hoon MA, Adler E, Feng L, Guo W, Zuker CS, Ryba NJP 
(2000) T2Rs Function as Bitter Taste Receptors. Cell 100:703-711.

Chang RB, Waters H, Liman ER (2010) A proton current drives action potentials in genetically identified sour taste cells. Proc Natl Acad Sci 107:22320-22325.

Chen C-K, Burns ME, He W, Wensel TG, Baylor DA, Simon MI (2000) Slowed recovery of rod photoresponse in mice lacking the GTPase accelerating protein RGS9-1. Nature 403:557-560.

Cohen SP, Buckley BK, Kosloff M, Garland AL, Bosch DE, Cheng G, Radhakrishna H, Brown MD, Willard FS, Arshavsky VY, Tarran R, Siderovski DP, Kimple AJ (2012) Regulator of G-protein signaling-21 (RGS21) is an inhibitor of bitter gustatory signaling found in lingual and airway epithelia. J Biol Chem 287:41706-41719.

Damak S, Rong M, Yasumatsu K, Kokrashvili Z, Pérez CA, Shigemura N, Yoshida R, Mosinger B, Glendinning JI, Ninomiya Y, Margolskee RF (2006) Trpm5 null mice respond to bitter, sweet, and umami compounds. Chem Senses 31:253-264.

Dando R, Dvoryanchikov G, Pereira E, Chaudhari N, Roper SD (2012) Adenosine enhances sweet taste through A2B receptors in the taste bud. J Neurosci 32:322330.

DeSimone JA, Ferrell F (1985) Analysis of amiloride inhibition of chorda tympani taste response of rat to $\mathrm{NaCl}$. Am J Physiol 249:R52-R61.

Duncan CJ (1962) Salt Preferences of Birds and Mammals. Physiol Zool 35:120-132. Eddy MC, Eschle BK, Barrows J, Hallock RM, Finger TE, Delay ER (2009) Double P2X2/P2X3 purinergic receptor knockout mice do not taste $\mathrm{NaCl}$ or the artificial sweetener SC45647. Chem Senses 34:789-797. 
Eylam S, Spector AC (2005) Taste discrimination between $\mathrm{NaCl}$ and $\mathrm{KCl}$ is disrupted by amiloride in inbred mice with amiloride-insensitive chorda tympani nerves. Am J Physiol Regul Comp Physiol 288:1361-1368.

Ferkey DM, Hyde R, Haspel G, Dionne HM, Hess HA, Suzuki H, Schafer WR, Koelle MR, Hart AC (2007) C. elegans G Protein Regulator RGS-3 Controls Sensitivity to Sensory Stimuli. Neuron 53:39-52.

Finger TE, Danilova V, Barrows J, Bartel DL, Vigers AJ, Stone L, Hellekant G, Kinnamon SC (2005) ATP Signaling Is Crucial for Communication from Taste Buds to Gustatory Nerves. Science 310:1495-1499.

Freedman NJ, Lefkowitz RJ (1996) Desensitization of G protein-coupled receptors.

Recent Prog Horm Res 51:319-353.

Garzón J, Rodríguez-Díaz M, López-Fando A, Sánchez-Blázquez P (2001) RGS9

proteins facilitate acute tolerance to mu-opioid effects. Eur J Neurosci 13:801-811.

Glendinning Jl, Gresack J, Spector AC (2002) A high-throughput screening procedure for identifying mice with aberrant taste and oromotor function. Chem senses $27: 461-474$.

Halpern BP (1998) Amiloride and vertebrate gustatory responses to $\mathrm{NaCl}$. Neurosci

Biobehav Rev 23:5-47.

Hayashi S, McMahon AP (2002) Efficient Recombination in Diverse Tissues by a Tamoxifen-Inducible Form of Cre: A Tool for Temporally Regulated Gene Activation/Inactivation in the Mouse. Dev Biol 244:305-318.

He W, Cowan CW, Wensel TG (1998) RGS9, a GTPase accelerator for 
phototransduction. Neuron 20:95-102.

Heck GL, Mierson S, DeSimone JA (1984) Salt taste transduction occurs through an amiloride-sensitive sodium transport pathway. Science 223:403-405.

Hisatsune C, Yasumatsu K, Takahashi-Iwanaga H, Ogawa N, Kuroda Y, Yoshida R, Ninomiya Y, Mikoshiba K (2007) Abnormal taste perception in mice lacking the type 3 inositol 1,4,5-trisphosphate receptor. J Biol Chem 282:37225-37231.

Houpt TA, Frankmann SP (1996) TongueTwister: an integrated program for analyzing lickometer data. Physiol Behav 60:1277-1283.

Hu G, Wensel TG (2002) R9AP, a membrane anchor for the photoreceptor GTPase accelerating protein, RGS9-1. Proc Natl Acad Sci 99:9755-9760.

Huang L, Shanker YG, Dubauskaite J, Zheng JZ, Yan W, Rosenzweig S, Spielman AI, Max M, Margolskee RF (1999) Gy13 colocalizes with gustducin in taste receptor cells and mediates IP3 responses to bitter denatonium. Nat Neurosci 2:1055-1062.

Huang Y, Dando R, Roper S (2009) Autocrine and paracrine roles for ATP and serotonin in mouse taste buds. J Neurosci 29:13909-13918.

Hwang I-Y, Park C, Harrison K, Boularan C, Galés C, Kehrl JH (2015) An Essential Role for RGS Protein/Gai2 Interactions in B Lymphocyte-Directed Cell Migration and Trafficking. J Immunol 194:2128-2139.

Ishiwatari Y, Bachmanov AA (2009) A high-throughput method to measure $\mathrm{NaCl}$ and acid taste thresholds in mice. Chem Senses 34:277-293.

Ishiwatari Y, Bachmanov AA (2012) Nacl taste thresholds in 13 inbred mouse strains. Chem Senses 37:497-508. 
Kataoka S, Baquero A, Yang D, Shultz N, Vandenbeuch A, Ravid K, Kinnamon SC, Finger TE (2012) A2BR adenosine receptor modulates sweet taste in circumvallate taste buds. PLoS One 7:e30032.

Kataoka S, Toyono T, Seta Y, Ogura T, Toyoshima K (2004) Expression of P2Y 1 receptors in rat taste buds. Histochem Cell Biol 121:419-426.

Kimple AJ, Bosch DE, Giguère PM, Siderovski DP (2011) Regulators of G-protein signaling and their Ga substrates: promises and challenges in their use as drug discovery targets. Pharmacolo Rev 63:728-749.

Kimple AJ, Garland AL, Cohen SP, Setola V, Willard FS, Zielinski T, Lowery RG, Tarran R, Siderovski DP (2014) RGS21, a regulator of taste and mucociliary clearance? Laryngoscope 124:E56-E63.

Kinnamon SC, Finger TE (2013) A taste for ATP: neurotransmission in taste buds. Front Cell Neurosci 7:264.

Kusakabe Y, Yasuoka A, Asano-Miyoshi M, Iwabuchi K, Matsumoto I, Arai S, Emori Y, Abe K (2000) Comprehensive study on G protein alpha-subunits in taste bud cells, with special reference to the occurrence of Galphai2 as a major Galpha species. Chem Senses 25:525-531.

Lambert NA, Johnston CA, Cappell SD, Kuravi S, Kimple AJ, Willard FS, Siderovski DP (2010) Regulators of G-protein Signaling accelerate GPCR signaling kinetics and govern sensitivity solely by accelerating GTPase activity. Proc Natl Acad Sci 107:7066-7071.

Lewandowski BC, Sukumaran SK, Margolskee RF, Bachmanov AA (2016) Amiloride- 
Insensitive Salt Taste Is Mediated by Two Populations of Type III Taste Cells with

Distinct Transduction Mechanisms. J Neurosci 36:1942-1953.

Li X, Staszewski L, Xu H, Durick K, Zoller M, Adler E (2002a) Human receptors for sweet and umami taste. Proc Natl Acad Sci 99:4692-4696.

Li X, Staszewski L, Xu H, Durick K, Zoller M, Adler E (2002b) Human receptors for sweet and umami taste. Proc Natl Acad Sci 99:4692-4696.

Lindemann B (2001) Receptors and transduction in taste. Nature 413:219-225.

Madisen L, Zwingman TA, Sunkin SM, Oh SW, Zariwala HA, Gu H, Ng LL, Palmiter RD, Hawrylycz MJ, Jones AR, Lein ES, Zeng H (2010) A robust and high-throughput Cre reporting and characterization system for the whole mouse brain. Nat Neurosci 13:133-140.

McLaughlin SK, McKinnon PJ, Margolskee RF (1992) Gustducin is a taste-cell-specific G protein closely related to the transducins. Nature 357:563-569.

Ming D, Ruiz-Avila L, Margolskee RF (1998) Characterization and solubilization of bitter-responsive receptors that couple to gustducin. Proc Natl Acad Sci 95:89338938.

Montmayeur JP, Liberles SD, Matsunami H, Buck LB (2001) A candidate taste receptor gene near a sweet taste locus. Nat Neurosci 4:492-498.

Nelson G, Chandrashekar J, Hoon MA, Feng L, Zhao G, Ryba NJP, Zuker CS (2002) An amino-acid taste receptor. Nature 416:199-202.

Nelson G, Hoon MA, Chandrashekar J, Zhang Y, Ryba NJ, Zuker CS (2001) Mammalian sweet taste receptors. Cell 106:381-390. 
Nishiguchi KM, Sandberg MA, Kooijman AC, Martemyanov KA, Pott JWR, Hagstrom SA, Arshavsky VY, Berson EL, Dryja TP (2004) Defects in RGS9 or its anchor protein R9AP in patients with slow photoreceptor deactivation. Nature 427:75-78.

Oka Y, Butnaru M, von Buchholtz L, Ryba NJP, Zuker CS (2013) High salt recruits aversive taste pathways. Nature 494:472-475.

Rajagopal S, Shenoy SK (2018) GPCR desensitization: Acute and prolonged phases. Cell Signal 41:9-16.

Roper SD (2015) The taste of table salt. Pflugers Arch Eur J Physiol 467:457-463. Sambi BS, Hains MD, Waters CM, Connell MC, Willard FS, Kimple AJ, Pyne S, Siderovski DP, Pyne NJ (2006) The effect of RGS12 on PDGFbeta receptor signalling to p42/p44 mitogen activated protein kinase in mammalian cells. Cell signal 18:971-981.

Schroer AB, Gross JD, Kaski SW, Wix K, Siderovski DP, Vandenbeuch A, Setola V (2018) Development of full sweet, umami, and bitter taste responsiveness requires Regulator of G protein Signaling-21 (RGS21). Chem Senses.

Shindo Y, Miura H, Carninci P, Kawai J, Hayashizaki Y, Ninomiya Y, Hino A, Kanda T, Kusakabe $Y(2008)$ Ga14 is a candidate mediator of sweet/umami signal transduction in the posterior region of the mouse tongue. Biochem Biophys Res Commun 376:504-508.

Siderovski DP, Willard FS (2005) The GAPs, GEFs, and GDIs of heterotrimeric Gprotein alpha subunits. Int J Biol Sci 1:51-66.

Snow BE, Hall RA, Krumins AM, Brothers GM, Bouchard D, Brothers CA, Chung S, 
Mangion J, Gilman AG, Lefkowitz RJ, Siderovski DP (1998) GTPase Activating

Specificity of RGS12 and Binding Specificity of an Alternatively Spliced PDZ (PSD95/Dlg/ZO-1) Domain. J Biol Chem 273:17749-17755.

Sohal DS, Nghiem M, Crackower MA, Witt SA, Kimball TR, Tymitz KM, Penninger JM, Molkentin JD (2001) Temporally regulated and tissue-specific gene manipulations in the adult and embryonic heart using a tamoxifen-inducible Cre protein. Circ Res 89:20-25.

Stellar E, Hill JH (1952) The rats rate of drinking as a function of water deprivation. J Comp Physiol Psychol 45:96-102.

Sukumaran SK, Lewandowski BC, Qin Y, Kotha R, Bachmanov AA, Margolskee RF (2017) Whole transcriptome profiling of taste bud cells. Sci Rep 7:7595.

Taruno A, Vingtdeux V, Ohmoto M, Ma Z, Dvoryanchikov G, Li A, Adrien L, Zhao H, Leung S, Abernethy M, Koppel J, Davies P, Civan MM, Chaudhari N, Matsumoto I, Hellekant G, Tordoff MG, Marambaud P, Foskett JK (2013) CALHM1 ion channel mediates purinergic neurotransmission of sweet, bitter and umami tastes. Nature 495:223-226.

Tordoff MG, Ellis HT, Aleman TR, Downing A, Marambaud P, Foskett JK, Dana RM, McCaughey SA (2014) Salty taste deficits in CALHM1 knockout mice. Chem Senses 39:515-528.

Tsao P, von Zastrow M (2000) Downregulation of G protein-coupled receptors. Curr Opin Neurobiol 10:365-369.

Tu Y-H, Cooper AJ, Teng B, Chang RB, Artiga DJ, Turner HN, Mulhall EM, Ye W, Smith 
AD, Liman ER (2018) An evolutionarily conserved gene family encodes protonselective ion channels. Science 359:1047-1050.

Vandenbeuch A, Anderson CB, Kinnamon SC (2015a) Mice lacking pannexin 1 release ATP and respond normally to all taste qualities. Chem Senses 40:461-467.

Vandenbeuch A, Clapp TR, Kinnamon SC (2008) Amiloride-sensitive channels in type I fungiform taste cells in mouse. BMC Neurosci 9:1-13.

Vandenbeuch A, Larson ED, Anderson CB, Smith SA, Ford AP, Finger TE, Kinnamon SC (2015b) Postsynaptic P2X3-containing receptors in gustatory nerve fibres mediate responses to all taste qualities in mice. J Physiol 593:1113-1125.

von Buchholtz L, Elischer A, Tareilus E, Gouka R, Kaiser C, Breer H, Conzelmann S (2004) RGS21 is a novel regulator of G protein signalling selectively expressed in subpopulations of taste bud cells. Eur J Neurosci 19:1535-1544.

Watson N, Linder ME, Druey KM, Kehrl JH, Blumer KJ (1996) RGS family members: GTPase-activating proteins for heterotrimeric G-protein alpha-subunits. Nature 383:172-175.

Willard MD, Willard FS, Li X, Cappell SD, Snider WD, Siderovski DP (2007) Selective role for RGS12 as a Ras/Raf/MEK scaffold in nerve growth factor-mediated differentiation. EMBO J 26:2029-2040.

Wong GT, Gannon KS, Margolskee RF (1996) Transduction of bitter and sweet taste by gustducin. Nature 381:796-800.

Woolf PJ, Linderman JJ (2003) Untangling ligand induced activation and desensitization of G-protein-coupled receptors. Biophys J 84:3-13. 
Yao TP, Oh SP, Fuchs M, Zhou ND, Ch'ng LE, Newsome D, Bronson RT, Li E, Livingston DM, Eckner R (1998) Gene dosage-dependent embryonic development and proliferation defects in mice lacking the transcriptional integrator p300. Cell 93:361-372.

Ye W, Chang RB, Bushman JD, Tu Y-H, Mulhall EM, Wilson CE, Cooper AJ, Chick WS, Hill-Eubanks DC, Nelson MT, Kinnamon SC, Liman ER (2016) The K + channel K IR 2.1 functions in tandem with proton influx to mediate sour taste transduction. Proc Natl Acad Sci 113:E229-E238.

Zhang Y, Hoon MA, Chandrashekar J, Mueller KL, Cook B, Wu D, Zuker CS, Ryba NJP (2003) Coding of sweet, bitter, and umami tastes: Different receptor cells sharing similar signaling pathways. Cell 112:293-301.

Zhao GQ, Zhang Y, Hoon MA, Chandrashekar J, Erlenbach I, Ryba NJP, Zuker CS (2003) The receptors for mammalian sweet and umami taste. Cell 115:255-266.

Zukerman S, Ackroff K, Sclafani A (2011) Rapid post-oral stimulation of intake and flavor conditioning by glucose and fat in the mouse. Am J Physiol Regul Integr Comp Physiol 301:1635-1647. 


\section{Chapter 4: Project insights and future directions}

\subsection{RGS21 in taste responsiveness}

Our group's observations of reduced responses to bitter, sweet, umami, and salty taste stimuli upon Rgs21 loss run opposite to prior expectations built upon the general knowledge of RGS proteins as negative regulators of GPCR signaling (Siderovski and Willard, 2005; Lambert et al., 2010; Woodard et al., 2015); moreover, observations from $\operatorname{Rgs} 21^{\Delta 5 / \Delta 5}$ mice run counter to prior findings from our group that acute Rgs21 knockdown in tastant-responsive bronchial epithelial cells leads to amplified second messenger levels upon exposure to the bitterant denatonium (Cohen et al., 2012).

RGS proteins, like RGS21, accelerate inactivation of GPCR-activated $G \alpha$ subunits (Berman et al., 1996; Watson et al., 1996; Snow et al., 1998; Cohen et al., 2012; Kimple et al., 2014); therefore, the loss of Rgs21 is expected to potentiate signaling by agonist-occupied GPCRs (Lambert et al., 2010; Kimple et al., 2011), such as the tastant-responsive T1Rs and T2Rs of Type II taste cells (Adler et al., 2000; Chandrashekar et al., 2000; Montmayeur et al., 2001; Nelson et al., 2001, 2002; Bufe et al., 2002; Li et al., 2002; Zhao et al., 2003) and/or the ATP-mediated autocrine feedback via purinergic $\mathrm{P} 2 \mathrm{Y}$ receptors and adenosine $\mathrm{A} 2 \mathrm{~B}$ receptors thought to support Type II cell signaling via extracellular ATP/ADP/adensoine-mediated potentiation of further ATP release (Huang et al., 2009; Dando et al., 2012; Kataoka et al., 2012; Kinnamon and Finger, 2013). In either case, GPCR-targeting tastants should be more potent upon 
RGS21 loss, and thus we originally expected the behavioral taste tests and chorda tympani nerve responses to show a leftward shift for sweetener and umami preference and bitter avoidance in $R g s 21^{\Delta 5 / \Delta 5}$ mice vs wild-type littermates. Instead, a rightward shift was seen for preference to sweeteners (sucrose and SC45647), and umami compounds (monosodium glutamate), and for aversion to bitterants (quinine and denatonium) (Figures 2.5, 2.6, \& 3.1) (Schroer et al., 2018). Thus, loss of RGS21 probably leads to hyperactivity of tastant GPCRs and/or one or more taste-promoting regulatory GPCRs (e.g. P2YR1/R2, adenosine A2B receptor), eventually causing their desensitization and/or downregulation (Figure 4.1). In the absence of RGS21, prolonged activity of G proteins in Type II taste cells may increase kinase-mediated phosphorylation and desensitization, and ultimately result in downregulation of receptors (Freedman and Lefkowitz, 1996; Rajagopal and Shenoy, 2018). Theoretical modeling has predicted that a decrease to the $G$ protein inactivation rate constant, which is expected in the absence of RGS21, would decrease the ratio of G protein activation to receptor phosphorylation (i.e., would increase receptor phosphorylation) (Woolf and Linderman, 2003). Additionally, a role for these proteins in ligand-mediated desensitization has been reported for mice with impaired RGS function (Garzón et al., 2001; Ferkey et al., 2007; Hwang et al., 2015). 


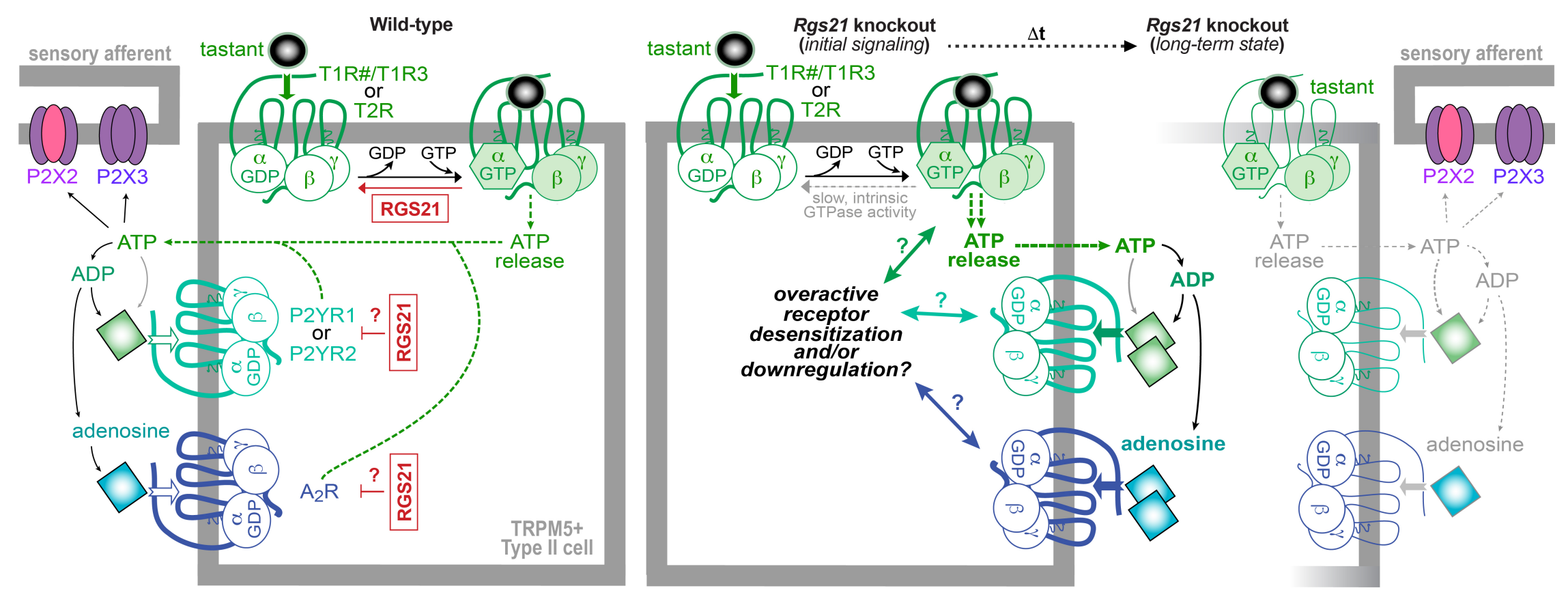

Figure 4.1. Hypothesis for how Rgs21 deletion leads to decreased tastant responsiveness, despite the prediction of augmented potency (Lambert et al., 2010) of GPCR-directed tastants in the absence of RGS protein GAP activity. In wildtype tastant-responsive Type II cells (left), RGS21 GAP activity decreases the inherent potency of tastants on GPCRinduced ATP release (dotted green arrow) by stimulating Go.GTP inactivation (Lambert et al., 2010). RGS21 may similarly inhibit signaling from support receptors in the Type II cell (e.g., purinergic P2YRs, adenosine A2BR; red question marks). We and others have shown that, with reduction or loss of Rgs21 expression (middle), the lifetime of activated Go.GTP is increased and, thus, tastant signaling is enhanced (e.g., increased second messenger production from denatonium-responsive T2Rs; refs. (Cohen et al., 2012; Kimple et al., 2014)). Such enhanced tastant-initiated signaling in the short-term should lead acutely to increased ATP release by Type II taste cells (bold green arrows). We hypothesize that this enhanced tastant-initiated signaling by T1R and T2R receptors will desensitize the receptors over time and may also lead to receptor downregulation. In addition, increased ATP release may lead, in the long-term, to desensitization and/or downregulation of downstream GPCRs responsive to ATP and/or its catabolic products ADP and adenosine. 
Alternatively, if hyperactive G protein signaling in Type II taste cells does not lead to desensitization of GPCRs, reduced responsiveness towards GPCR-mediated taste stimuli in $R g s 21^{\Delta 5 / \Delta 5}$ mice may be explained by desensitization at the level of the taste nerve fiber. Loss of RGS21 in Type II taste cells is expected to result in prolonged signaling of GPCRs and, subsequently, a prolonged elevation of extracellular ATP. Such prolonged elevation of ATP could desensitize purinergic receptors on the afferent nerve fiber (Figure 4.2). The purinergic receptors expressed on the afferent nerve fiber are hetero- and homo-trimers of P2X2 and P2X3 subunits (Bo et al., 1999); 50-60\% of taste nerve fibers express the P2X2 unit, while nearly all neurons express P2X3 (Ishida et al., 2009). Pharmacological blockade of $P 2 X 3$ and, thereby, of $P 2 X 3$ homotrimers and P2X2/P2X3 heterotrimers, is sufficient to fully block responses to all taste qualities (Vandenbeuch et al., 2015b), suggesting a central functional role for P2X3 subunits in the taste system. P2X3 subunits quickly desensitize with prolonged exposure to ATP (North, 2002). Additionally, there is precedence for desensitization and loss of taste responsiveness with elevated ATP levels: e.g., in mice lacking NTPDase2, an ectonucleotidase that degrades extracellular ATP (Vandenbeuch et al., 2013). 

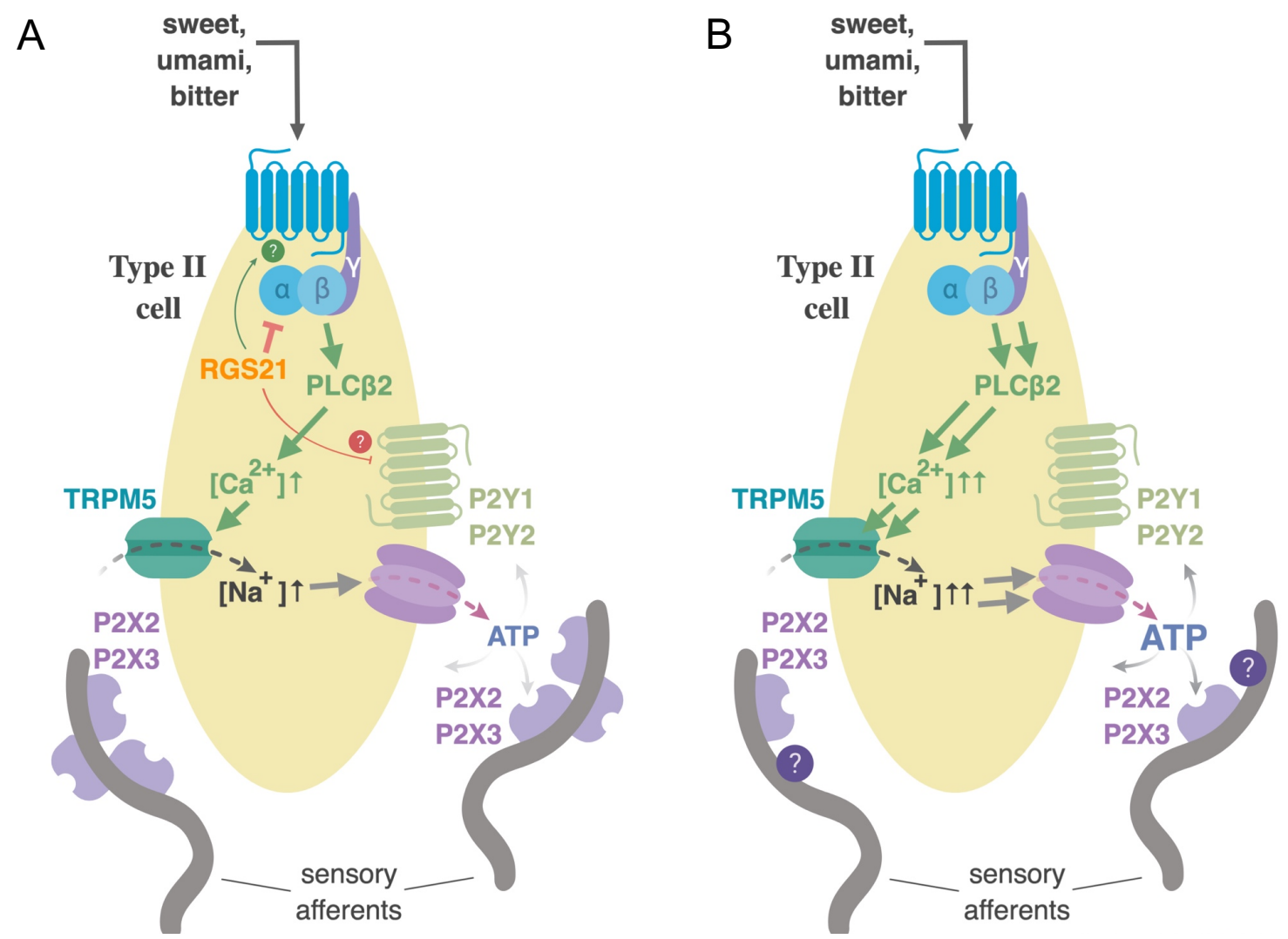

Figure 4.2. (A) Model of RGS21 action(s) in modulating signal transduction from GPCRs expressed by Type II taste cells. RGS proteins are characterized by their GAP activity on $\mathrm{G} \alpha$ subunits (red inhibitory symbol); in addition, the consequences of RGS protein knockdown in other systems (Garzón et al., 2001; Laroche et al., 2010) suggests that RGS proteins are also supportive of stable GPCR surface expression and/or coupling to $G$ proteins (green arrow and question mark). RGS21 GAP activity may not be restricted to T1R and T2R GPCR signaling, and thus may also influence purinergic $\mathrm{P} 2 \mathrm{Y}$ autocrine/paracrine signal transduction (red inhibitory symbol and question mark). (B) In the absence of RGS21 expression, the lifetime of activated Ga.GTP is increased, leading to increased second messenger production and increased ATP release. The latter may drive desensitization and/or downregulation of purinergic $\mathrm{P} 2 \mathrm{X}$ receptors on juxtaposed sensory afferents (purple question mark).

It is likely that removal of RGS21 leads to decreased peripheral taste responses that emanate from the Type II cells in one of these ways. Future work is needed to determine at which level, the taste receptor cell or the afferent gustatory nerve, loss of GAP activity causes desensitization of peripheral taste responses and thus the level of 
the gustatory system likely most sensitive to taste adaptation. Candidate experimental approaches to interrogate these questions are described below.

Targeting of Rgs21 for genetic ablation by homologous recombination has also highlighted an underappreciated role for GPCR / G protein signaling in the appetitive effects of moderate salt concentrations. $R g s 21^{\Delta 5 / \Delta 5}$ mice exhibited a reduced appetitive response to moderate concentrations of $\mathrm{NaCl}(37.5-150 \mathrm{mM}$; Figure $2.5 \mathrm{~F})$ and $\mathrm{KCl}$ (100 and $200 \mathrm{mM}$; Figure 3.4) in two-bottle choice experiments and a trend towards a reduction in CT nerve response to $100 \mathrm{mM} \mathrm{NaCl}$ lingual exposure (Figure 2.6). Although salt taste has traditionally not been considered under the purview of GPCR signaling in Type II taste cells per se, these observations support the hypothesis recently posited by Tordoff and colleagues (Tordoff et al., 2014) that the taste of moderate concentrations of salt are transduced in part by GPCR signaling cascades, culminating in release of ATP from CALHM1, the ATP release channel expressed exclusively in Type II taste bud cells (Taruno et al., 2013). Other components of GPCR-mediated taste signal transduction in Type II cells have also been implicated in the taste response to moderate concentrations of $\mathrm{NaCl}$ (Damak et al., 2006; Hisatsune et al., 2007); however, these findings have been inconsistent (Wong et al., 1996; Zhang et al., 2003). The mechanism(s) whereby moderate concentrations of salt may activate Type II taste cells is not yet clear. However, $\mathrm{NaCl}$ may activate a receptor sensitive to salts on Type II cells or these cells may become active via communication from other salt-responsive cell types (Tordoff et al., 2014). Further characterization of salt taste responses in Rgs21-deficient mice will help reveal the mechanism whereby GPCR signaling in Type II taste cells may mediate appetitive responses to moderate concentrations of salt. 
There are likely additional novel regulators of tastant signaling and novel modes of tastant-germane $G$ protein signaling to discover by studying the role(s) of RGS proteins in tastant-responsive cells. Recent RNA-Seq data, highlighted in Chapter 3, revealed pronounced expression of Rgs7, Rgs8, and Rgs12 in Tas1r3+ cells without detectable expression in Type III taste cells (Figure 3.6) (Sukumaran et al., 2017). Based on our behavioral data from Rgs21-deficient mice, it is tempting to speculate that one or more of these other RGS proteins (encoded by these genes in Fig. 3.6) also play(s) a key role in tastant signaling. Examining the taste responses in mice lacking Rgs7 and Rgs12, in addition to parallel studies of Rgs21-deficient mice, should provide further insight into the role of RGS proteins in taste signaling. RGS21, RGS12, and RGS7 are three very different RGS proteins in terms of their multi-domain architectures (Figure 4.3); therefore, these proteins may regulate signaling in Type II taste cells in very different ways and may identify specific and divergent functions for different RGS family members in peripheral taste signaling. 


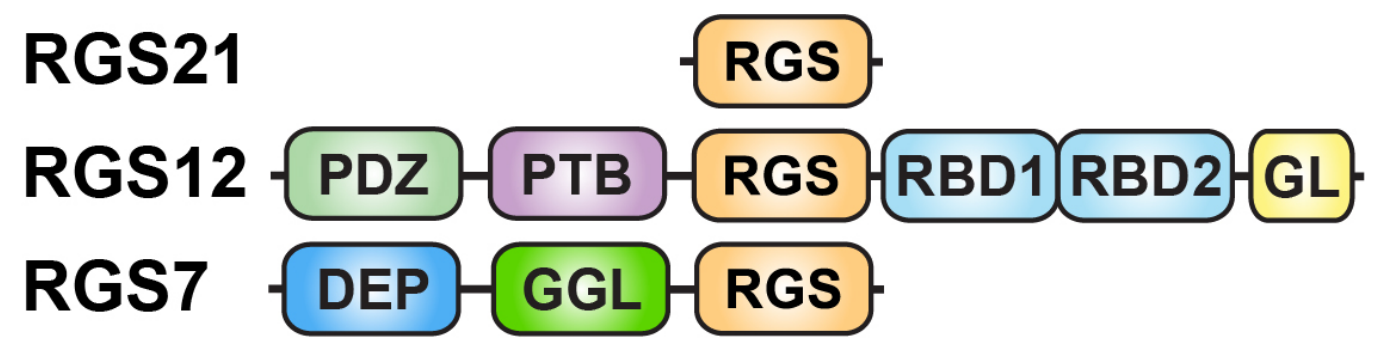

Figure 4.3. RGS proteins to be pursued in future investigations. Each protein contains an RGS domain (orange) that binds $G \alpha$ to accelerate GTPase activity (Lambert et al., 2010; Kimple et al., 2011). RGS21, the smallest of the RGS proteins, has no additional domains. RGS12 possesses additional interaction sites: a PDZ domain that binds MEK2 (Willard et al., 2007); a phosphotyrosine-binding (PTB) domain (Uhlik et al., 2005); two Ras-binding domains (RBDs) that bind H-Ras and B-Raf (Willard et al., 2007), and a GoLoco motif that binds Go.GDP (Kimple et al., 2001) for endosomal targeting (Sambi et al., 2006). RGS7 contains an N-terminal DEP domain responsible for binding its membrane-anchoring protein partner R7BP (Anderson et al., 2010; Terzi et al., 2012; Ostrovskaya et al., 2014) and a central GGL domain that binds the heterotrimeric G protein subunit G $\beta 5$ (Snow et al., 1999; Cheever et al., 2008).

\subsection{Approach}

Available mouse strains to be employed in future pursuits:

Trpm5-IRES-Cre (knockin; Cre recombinase driver) - Transient receptor potential channel subfamily M member 5 (TRPM5) is a key downstream signaling component of Type II taste receptor cells - as highlighted above (Pérez et al., 2002; Huang and Roper, 2010). Trpm5 mRNA is highly restricted in its expression pattern: i.e., highly expressed in oral gustatory tissue, with lower expression levels in the stomach and small intestine (e.g., solitary chemosensory cells). Dr. Ulrich Boehm has provided the Setola lab access to his group's Trpm5-IRES-Cre knockin mouse strain (Kusumakshi et al., 2015) so that genetic ablation of floxed Rgs alleles can be constrained (to the best of our present ability) to Type II taste receptor cells and extra-oral gustatory tissues. 


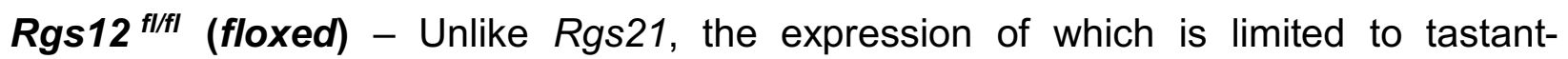
responsive cells, Rgs12 is also expressed in other tissues (Snow et al., 1998; MartinMcCaffrey et al., 2005; Willard et al., 2007; Gross et al., 2018). Therefore, exploiting the conditional 'floxed' nature of the Rgs12 allele, which the Siderovski lab possesses (Gross et al., 2018), in combination with taste receptor cell type-specific Cre mouse driver strains, e.g., Trpm5-IRES-Cre, to restrict excision of Rgs12 to tastant-responsive cells, will provide insight into the particular role of RGS12 in taste receptor sensation.

Rgs7 ${ }^{\text {flfl }}$ (floxed) - Like Rgs12, Rgs7 is expressed in Type II taste cells (Fig. 3.6) but also expressed in CNS neurons (Xie et al., 2010; Cao et al., 2012; Ostrovskaya et al., 2014; Aguado et al., 2016; Sarria et al., 2016). Again, exploiting the floxed nature of the Rgs7 allele, which Dr. Kiril Martemyanov has provided to the Setola lab, in combination with available taste receptor cell-type specific Cre mouse driver strains, e.g., Trpm5IRES-Cre, to restrict genetic ablation of Rgs7 to peripheral taste tissue, will be used to determine if RGS7 has a role in peripheral taste signaling.

\subsubsection{Identify the roles of RGS proteins expressed in taste cells in modulating taste responses}

4.2.1a. Two-bottle choice tests to delineate effects of Rgs gene loss on tastant preference or aversion

Rationale: While a function of RGS21 in behavioral taste responses has been documented, it is unknown if RGS7 or RGS12 function in Type II taste cells to regulate GPCR-mediated taste signaling. Therefore, a central focus of future experiments should be to ascertain the full extent of the loss of RGS12 and RGS7 in behavioral taste responses to GPCR-mediated taste qualities. 
Method: In applying the two-bottle choice test (Tordoff, 2007) with each, constitutive,

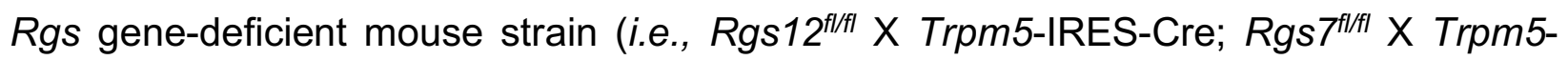
IRES-Cre), one would first give individually-housed mice access to two bottles containing water for $48 \mathrm{hr}$ prior to all testing. Mice would then undergo $48 \mathrm{hr}$ tests with a choice between water and ascending concentrations of a taste solution. The positions of the bottles would be switched daily and fluid intake recorded. Preference ratio would be calculated as volume of tastant solution consumed divided by volume of total solution consumed. The taste compounds would be chosen as exemplars of the sweet (Sclafani and Glendinning, 2003, 2005; Bachmanov et al., 2008) (sucrose, SC45647), bitter (Boughter et al., 2005) (denatonium benzoate, quinine sulfate), umami (Damak et al., 2006) (monosodium glutamate [MSG] $+10 \mu \mathrm{M}$ amiloride), salty (Bachmanov et al., 1998, 2002) ( $\mathrm{NaCl}, \mathrm{KCl})$, and sour (Nelson et al., 2010) ( $\mathrm{HCl}$, citric acid) taste qualities, and their concentrations would span the range between indifference and marked acceptance or avoidance.

With a strict eye to rigor and reproducibility, these (and all other) tests would be conducted with equal numbers of wild-type littermate controls and analyzed using the ARRIVE guidelines for animal research (Kilkenny et al., 2010). Dose-response data would be plotted on a semi-logarithmic scale using Prism 7; given that behavioral responses in the two-bottle choice test depend on peripheral nerve input, post-ingestive factors, hedonics, and central integration (e.g., ref. (Damak et al., 2006)), we would not over-model the behavioral data with the standard sigmoidal dose-response relationship (i.e., 3-parameter logistic equation used in pharmacology (Neubig et al., 2003)). 
Alternatives and other considerations: Our initial data from the two-bottle choice assay, using $\operatorname{Rgs} 21^{\Delta 5 / \Delta 5}$ mice, suggest that RGS21 functions in the appetitive preference for moderate amounts of $\mathrm{NaCl}$ (Fig. 2.4C). Thus, we must now also test salt responses (both preference for moderate doses and aversion to high concentrations) of Rgs21 ${ }^{f / f l}$ X TRPM5-IRES-Cre mice, given that this particular cross breeding will constrain RGS21 loss to Type II taste cells and thereby allow us to potentially exclude any proximal role for RGS21 in non-Type II cell salt signaling (e.g., in the case, albeit remote, of RGS21 expression in Type I or Type III taste cells, or other gustatory/supportive cell types lacking Trpm5 expression). While our group (Cohen et al., 2012; Kimple et al., 2014) and others (von Buchholtz et al., 2004) have reported in situ hybridization data supporting the restricted expression of Rgs21 solely in Tas1rand Tas2r-expressing, PLC $\beta 2+$ taste cells, employing this genetic means to constrain RGS21 loss to only Type II taste cells will resolve any doubts.

4.2.1b. Taste-salient brief-access choice tests to delineate the effect(s) of individual Rgs gene loss at the level of the integrated tastant response but without confounding post-ingestive effects

Rationale: As an organism's preference for particular compounds is heavily influenced by stimulatory post-oral signals (Zukerman et al., 2011), we also need to perform briefaccess taste tests to minimize the influence of certain post-oral factors (e.g., satiety, toxicity) in the assessment of behavioral taste responses of Rgs-deficient mice.

Method: For many of the tastants previously described above in 4.2.1a, brief-access taste tests (Stellar and Hill, 1952; Houpt and Frankmann, 1996) would be conducted in a Davis Rig Brief Access Lickometer (16-bottle capacity "legacy version"; Med 
Associates) as described previously (Glendinning et al., 2002). All animals would undergo three days of training (spout and shutter acclimation) to become accustomed to drinking from the Davis rig prior to testing. During spout acclimation, the mouse would be placed in the Davis rig, and the session would last for 30 min once the mouse takes its first lick. On the following two days of training (shutter acclimation), the mouse would be given access to the drinking tube with the shutter door open until $5 \mathrm{~s}$ after it takes its first lick. The door would remain closed for $7.5 \mathrm{~s}$ before re-opening with a different drinking tube revealed. The mouse would be allowed to initiate as many trials as possible during the 30 min training session (and all subsequent test sessions).

Prior to test sessions with aversive stimuli (i.e., bitter, sour, salty), mice would be water deprived for $22.5 \mathrm{~h}$ to enhance drinking behavior. Following each 30 -min testing session mice would be allowed to rehydrate with ad libitum access to water for $1 \mathrm{hr}$. To enhance drinking behavior towards normally-preferred stimuli (i.e., sweet and umami), mice would be restricted to $1 \mathrm{~g}$ of chow and $2 \mathrm{ml}$ of water for $22.5 \mathrm{~h}$ prior to each test session and allowed one recovery day (ad libitum food and water) following each session. Taste solutions would be presented in multiple randomized blocks for the duration of each $30 \mathrm{~min}$ session. During each test session the tastant/water lick ratio would be calculated and averaged across the three test sessions. Two-way repeated measures ANOVAs would be used to test for significant effects of genotype on the lick ratio.

Expected results: As Cre-mediated excision of each Rgs gene under study is to be constrained (to the best of our present ability) to taste receptor cells via the Trpm5IRES-Cre driver strain (Kusumakshi et al., 2015), we anticipate the effects of RGS 
protein loss will be manifest mainly (or exclusively) within changes to Type II celllocalized, tastant-elicited signaling. (However, future research pursuits will also need to explore other alternatives including developmental / morphological changes arising from loss of RGS protein expression.) Our initial data from brief-access tests of Rgs $21^{\Delta 5 / \Delta 5}$ mice vs wild-type littermates (Figure 3.1) confirm our anticipation: loss of aversion to the bitterant quinine and blunted preference to the sweetener sucrose is observed both in brief-access and two-bottle testing, suggesting that the latter phenotypes do not necessarily involve post-ingestive tastant effects.

4.2.1c. Nerve recordings to delineate effect of individual Rgs gene loss on gustatory neuronal afferents

Rationale: To test whether RGS protein loss leads to altered gustatory neuronal transmission, chorda tympani recordings and glossopharyngeal recordings (Kataoka et al., 2012; Vandenbeuch et al., 2013, 2015a, 2015b; Larson et al., 2015; Holstein-rathlou et al., 2016) would need to be conducted on Rgs-deficient mice and wild type littermate controls after lingual exposure to various tastants from the five known taste modalities of bitter, sweet, umami, sour, and salty. In this way, we would be able to ascertain whether each RGS protein is selective in its presumed function in peripheral taste signaling, or also serves a regulatory role in other post-ingestive, hedonic, or central integration process (i.e., distal from the originating event of a tastant/taste receptor interaction). For example, the blunted sucrose, umami, and quinine responses in Rgs $21^{\Delta 5 / \Delta 5}$ mice (Figure 2.6) reflect that the loss of RGS21 impairs peripheral taste signaling, likely via desensitization of GPCRs in Type II taste cells (Figure 4.1) or a 
potential deficit that develops in transmission to the afferent gustatory nerve (Figure 4.2).

Method: Rgs-deficient mice and wild-type littermates from each, constitutive, Rgs genedeficient mouse strain (Rgs12 $2^{f / f t} \times$ Trpm5-IRES-Cre; Rgs $7^{f / f l} \times$ Trpm5-IRES-Cre) would be bred for chorda tympani and glossopharyngeal recordings of lingual tastant responses, using established protocols which were used to assess $R g s 21^{\Delta 5 / \Delta 5}$ mice (Figure 2.6) as well as others published by our collaborator Dr. Vandenbeuch in additional gustatory afferent studies (Kataoka et al., 2012; Vandenbeuch et al., 2013, 2015a, 2015b; Larson et al., 2015; Holstein-rathlou et al., 2016). Anesthetized mice would be maintained in a head holder with trachea cannulated to facilitate breathing. The chorda tympani nerve would be exposed using a ventral approach, freed from surrounding tissue, and cut near the tympanic bulla. To expose the glossopharyngeal nerve, the digastric muscle would be removed and the nerve cut near its entrance to the posterior foramen. Nerves would then be placed on a platinum-iridium wire and a reference electrode placed in nearby tissue. Signal would be fed to an amplifier (P511; Grass Instr.), integrated and recorded using AcqKnowledge software (Biopac). For chorda tympani recordings, ten mice from each Rgs-deficient strain and ten wild-type littermate controls would be used for each stimulus; these numbers of mice have been found adequate for meaningful comparisons in past studies. Similarly, for glossopharyngeal recordings, a total of ten Rgs-deficient mice and ten wild-type littermates would be used for each strain of Cre-driven knockout. The fungiform papillae (for chorda tympani) or the circumvallate papilla (for glossopharyngeal nerve) would be independently stimulated with different tastants applied with a constant flow pump. 
Initial stimuli for chorda tympani recordings would include: $100 \mathrm{mM}$ of $\mathrm{NH}_{4} \mathrm{Cl} ; 3$, 10 , and $20 \mathrm{mM}$ of the bitterant quinine; 100,300 , and $500 \mathrm{mM}$ of monopotassium glutamate (MPG) $+0.5 \mathrm{mM}$ inosine 5'-monophosphate (IMP) (classically considered 'umami' although this combination in mice possesses perceptual similarity to sucrose (Saites et al., 2015)); 300, 500, and $1000 \mathrm{mM}$ of the natural carbohydrate sweetener sucrose; 50 and $100 \mathrm{mM}$ of the artificial sweetener saccharin; $100 \mathrm{mM}$ of $\mathrm{NaCl}$ (perceived as 'salty'); and either $10 \mathrm{mM}$ of citric acid or $10 \mathrm{mM} \mathrm{HCl}$ (sour). A more restricted set of stimuli would initially be used for the more technically demanding glossopharyngeal recordings: $10 \mathrm{mM}$ quinine; $100 \mathrm{mM}$ MPG + $0.5 \mathrm{mM}$ IMP (umami); $1000 \mathrm{mM}$ sucrose; $100 \mathrm{mM} \mathrm{NaCl}$; either $10 \mathrm{mM}$ of citric acid or $10 \mathrm{mM} \mathrm{HCl}$ (sour). Each stimulus would be applied separately for $30 \mathrm{~s}$ and then rinsed with water for $40 \mathrm{~s}$. To reduce any variability across animals, as well as potential signal run-down, each response would be normalized to the $100 \mathrm{mM} \mathrm{NH}_{4} \mathrm{Cl}$ response measured at the beginning and end of each train of tastants, as previously described (Kataoka et al., 2012; Vandenbeuch et al., 2013, 2015a, 2015b; Larson et al., 2015; Holstein-rathlou et al., 2016). To analyze nerve recording data, the amplitude of each integrated response would be averaged over the $30 \mathrm{~s}$ exposure time using AcqKnowledge software and compared between Rgs-deficient and wild-type mice with a two-way ANOVA when several concentrations of the same stimulus are applied (e.g., 300, 500, $1000 \mathrm{mM}$ sucrose), or compared with an unpaired Student's $t$-test for single concentration measurements (Prism 7).

Alternatives and expected results: Given recent evidence (Larson et al., 2015) that pentobarbital directly affects tastant neuronal transmission (via $5-\mathrm{HT}_{3}$ receptor inhibition 
(Jenkins et al., 1996; Barann et al., 1997, 2000)), urethane (2 g/kg, i.p.) would be used for anesthesia prior to nerve recordings, rather than pentobarbital. Should initial recording data suggest that the amplitude of the $\mathrm{NH}_{4} \mathrm{Cl}$ response is actually different in a particular Rgs-null strain relative to wild-type controls, all recording data would instead be normalized to baseline recording, as previously performed in NTPDase2 knockout mouse studies (Vandenbeuch et al., 2013).

As previously mentioned, Trpm5-IRES-Cre mediated excision of each Rgs gene should constrain (to the best of our present ability) RGS protein loss to Type II cells; this method was chosen to study the peripheral effect of RGS protein loss on lingual tissuelocalized tastant signaling, rather than on downstream, post-ingestive and/or central effects of tastants. We therefore anticipate that measured nerve recordings, downstream of lingual tastant sensing yet upstream of central perception, will directly reflect the changes in the integrated tastant-stimulated behaviors observed via 4.2.1a (two-bottle choice testing) and 4.2.1b (brief-access testing). Data from chorda tympani nerve recordings from $R g s 21^{\Delta 5 / \Delta 5}$ mice vs wild-type littermates (Figure 2.6) confirms our anticipation above: reductions in CT nerve responses to the T2R activator quinine and T1R activators MSG/IMP, sucrose, and SC45647 parallel the blunted aversion to bitterants and blunted preference to sweeteners and umami observed in brief-access and two-bottle testing, again suggesting that the latter phenotypes of $R g s 21^{\Delta 5 / \Delta 5}$ mice do not necessarily involve post-ingestive tastant effects.

RGS21, RGS12, and RGS7 are three very different RGS proteins (Fig. 4.3). RGS21 is the smallest, with minimal functionality (i.e., G $\alpha$-directed GAP activity (Lambert et al., 2010; Kimple et al., 2011, 2014; Cohen et al., 2012)). In contrast, RGS12 is a large 
scaffold protein that also interacts with Ras-family GTPases and members of the ERK MAPK cascade (Snow et al., 1998; Sambi et al., 2006; Willard et al., 2007; Gross et al., 2018); RGS7 also possesses additional protein-protein interaction domains and is implicated in coordinating heterotrimeric $G$ protein regulation of ion channel function (Anderson et al., 2009; Xie et al., 2010; Cao et al., 2012; Fajardo-Serrano et al., 2013; Sutton et al., 2016). Therefore, we predict that all three proteins have distinct and non-overlapping functions within T1r3+ taste receptor cells (i.e., distinct functions leading to distinct tastant responses upon loss of their expression) that would be revealed in the future research pursuits as articulated in sections $4.2 .1 \mathrm{a}, 4.2 .1 \mathrm{~b}$, and 4.2.1c above. We could also perform candidate gene transcript quantitative RT-PCR and even unbiased RNA-Seq transcriptomic studies (if required) on isolated lingual tissue and taste cells from Rgs-deficient and wild-type mice (e.g., similar to Figure 3.6) to ascertain whether any lack of phenotypic differences arises from compensatory upregulation of other Rgs genes after Cre-mediated excision of each of these loci under study. As Rgs21, Rgs12, and Rgs7 reside in different chromosomal locations (i.e., chromosomal locations $1 \mathrm{~F}, 5 \mathrm{~B} 2$, and $1 \mathrm{H} 3$, respectively), dual or even triple knockout strain creation is possible, if necessary, to reveal phenotypes and ascribe functions to these three proteins. 


\subsubsection{Establish the mechanism by which each relevant RGS protein affects peripheral taste signaling}

4.2.2a. Characterize each Rgs-deficient mouse strain for changes in taste cell complement / morphology

Rationale: We need to ascertain whether the behavioral and gustatory peripheral sensation phenotype(s) observed in the pursuits above are related to any developmental defect by the constitutive loss of RGS protein expression. For example, our observations of blunted taste responses upon RGS21 loss were derived from mice lacking a functional Rgs21 gene from initial conception. Therefore, we examined whether RGS21-deficient mice had an impairment to the developmental program (Mistretta et al., 1999; Barlow, 2015; Qin et al., 2018) that gives rise to gustatory papillae and their normal complement of taste cell types (Figures $2.3 \& 2.4-$ no impairment was found). In contrast, RGS12 and/or RGS7 may function to regulate Type II taste receptor cell regeneration; aberrations in morphology and/or cell complement may explain any altered taste preferences observed.

Methods: Lingual tissue morphology -- To determine if Rgs7 or Rgs12 loss affects development of gustatory papillae, we would compare multiple, independent, morphometric measurements from four Rgs-deficient mice of each strain and four wildtype littermates (i.e., age-matched, 15-25 days post-natal), similar to those performed on $R g s 21^{\Delta 5 / \Delta 5}$ mice (Schroer et al. 2018) and other previous studies (Mistretta et al., 1999; Vandenbeuch et al., 2013). Tongues would be dissected from mice perfused with 4\% paraformaldehyde in $0.1 \mathrm{M}$ phosphate, $\mathrm{pH} 7.4$; oral tongue length would be measured from tongue tip to the border between the oral and pharyngeal tongue (caudal to circumvallate papilla). To obtain circumvallate, fungiform, and foliate papillae, 
OCT-embedded frozen tongue would be mounted in three orientations to produce optimal sectioning (i) through the complete circumvallate papilla walls and inner connective tissue and through all circumvallate papilla taste buds, (ii) for complete cross sections through most fungiform papillae and taste buds (i.e., sagittal orientation for anterior tongue halves (Mistretta et al., 1999)), and (iii) for cross sections through foliate papillae in lateral grooves on each side of the posterior tongue. Serial, 8- $\mu \mathrm{m}$ sections would then be cut on a cryostat, mounted on gelatin-coated slides, and H\&E stained for light microscopy. Morphometric measurements would be performed on microscope images imported into ImageJ / Fiji. For example, we would compare sizes of the circumvallate papillae and the sizes and total number of taste buds.

Lingual tissue immunohistochemistry (IHC) and in situ hybridization (ISH) -- To determine if $R g s$ gene deletion affects the viability and integrity of taste buds or specific subtypes of taste cells, sections from the above three papillae would be singly-labeled with various taste cell markers, including Tas1r1, Tas1r2, Tas1r3, and mixed/pooled $T 2 R$ riboprobes, using our previously established IHC and ISH techniques (Cohen et al., 2012; Kimple et al., 2014) (Schroer et al 2018). This process would allow us to further assess the morphology and number of taste buds, as well as the specific complement of taste cell types in Rgs-deficient vs $R_{g s}^{+/+}$mice. Specifically, sections would be immunolabeled for KCNQ1, a voltage-gated potassium channel expressed in nearly all taste cells (Wang et al., 2009), or the taste cell marker Keratin 8 ('TROMA-1' from DSHB; ref. (Brûlet et al., 1980)), which would allow assessment of the general morphology and number of taste buds in Rgs-deficient $v s$ wild type mice. To determine whether loss of RGS7 or RGS12 differentially alters the complement of taste cell types, 
we would immunolabel sections with markers specific for Type I taste cells (e.g., GLAST; ref. (Lawton et al., 2000)), Type II taste receptor cells (e.g., PLCß2; ref. (Clapp et al., 2004)), and Type III taste cells (e.g., SNAP-25; ref. (Yang et al., 2000; Clapp et al., 2006)). To determine whether the composition or number of bitter cells is altered in Rgs-deficient mice, we would immunolabel $\alpha$-gustducin, which preferentially labels bitter cells in the foliate and circumvallate papillae (Hoon et al., 1995; Montmayeur et al., 2001). As an alternate to IHC, sections from the three papillae would be singly- and doubly-labeled using ISH with Rgs7, Rgs12, and Rgs21 riboprobes and various taste cell type-specific markers (as defined above).

Expected results: RGS12 supports nerve growth factor-mediated axonogenesis by dorsal root ganglion sensory neurons (Willard et al., 2007) and is therefore the most likely of these RGS proteins to function in a developmental capacity within lingual sensory epithelium. RGS7 shares a multifunctional protein architecture with RGS12 (Fig. 4.3) but, to-date, studies of the effect of its genetic ablation on CNS function have revealed its modulatory actions on neuronal signal transduction (Anderson et al., 2009; Xie et al., 2010; Cao et al., 2012; Fajardo-Serrano et al., 2013; Sutton et al., 2016), rather than neuronal development per se.

Observing altered numbers of specific taste cells within lingual tissue of an Rgsdeficient mouse strain would strengthen rationale for examining the consequences of RGS protein loss at the adult stage (i.e., avoiding any apparent RGS protein function in the development of tastant-responsive lingual epithelium). 
4.2.2b. Tamoxifen-induced Rgs gene loss, timed in adulthood to delineate whether changes in taste perception and/or taste cell complement/morphology arise from developmental perturbations

Approach: For further examining taste tissue morphology and perception phenotypes initially observed in $R g s 7^{f / f l} \times$ Trpm5-IRES-Cre mice and Rgs12 $12^{f / f l} \times$ Trpm5-IRES-Cre mice, we would also breed the $R g s 7^{f / f l l}$ and $R g s 12^{f f / f l}$ strains with a tamoxifen-inducible Cre driver - K5-CreERT2 knock-in (JAX \#029155) - in which Cre is expressed from the intact cytokeratin-5 gene, thereby driving Cre expression in basal epithelial cells including all taste cell types but also non-gustatory epithelium. As Rgs21 is already restricted to taste responsive cells, we instead bred the $\operatorname{Rgs} 21^{f / f f l}$ parental strain with C57BL/6J congenic, tamoxifen-inducible CAGGCre-ER ${ }^{\text {TM }}$ mice, as described in the preceding chapter.

\subsection{2c. Testing for evidence of receptor downregulation by immunoblot analyses}

Rationale: A potential cause of the decreased responses to GPCR-directed tastants observed with $\operatorname{Rgs} 21^{\Delta 5 / \Delta 5}$ mice is an initial increase/prolongation in taste receptor and support receptor signaling (due to loss of negative regulation on GPCR signaling) that, over time, leads to downregulation of taste receptors and/or support receptors. Canonically, prolonged desensitization of a GPCR leads to its downregulation (Luttrell and Lefkowitz, 2002; Rajagopal and Shenoy, 2018). Thus, we would attempt to quantify levels of T1R1, -2 , and -3 receptors by immunoblotting CV tissue of Rgs-deficient and wild-type mice.

Methods: We would isolate CV tissue using published methods as described above in prior subaims. Isolated CV tissue would then be prepared for immunoblot analysis using published methods (Ugawa et al., 2003; Martin et al., 2011). Briefly, tissue would be 
homogenized in $50 \mathrm{mM}$ Tris- $\mathrm{HCl}, \mathrm{pH}$ 7.5, $5 \mathrm{mM}$ EDTA, $150 \mathrm{mM} \mathrm{NaCl}, 1 \%$ Triton X-100, and complete protease inhibitors (Roche). Equal amounts of protein would be resolved by SDS-PAGE and transferred to polyvinylidene difluoride membranes (Immobilon-P; Millipore). Commercially available antibodies against mT1R1 (ab155143), mT1R2 (PA567756), and mT1R3 (LS-C496868) would be used at the recommended dilutions to perform immunoblot analysis. Membranes would be incubated in blocking solution of 10\% skim milk and $0.3 \%$ Tween 20 in Tris-buffered saline (TBS-T), and then incubated overnight at $4^{\circ} \mathrm{C}$ with primary anti-T1R antibody. The next day, the membranes would be washed three times with TBS-T solution, then detected with horseradish peroxidaselabeled secondary antibody (1-hr incubation in TBS-T at recommended dilution for immunoblotting) (Vector Labs; Burlingame, CA) and visualized using Super Signal West Pico PLUS chemiluminescent substrate (Fisher). Blots would be visualized on a GE ImageQuant Blot Imager, and band densitometry performed using Image J / Fiji software. Parallel or stripped immunoblots would be used to detect housekeeping proteins such as $\beta$-tubulin, GAPDH, or cyclophilin for normalizing to a loading control.

Expected Results and Alternatives: If our hypothesis as elaborated in Figure 4.1 is correct, decreased levels of T1R1, T1R2, and T1R3 in immunoblots of CV tissue homogenates may be observed from $\operatorname{Rgs} 21^{\Delta 5 / \Delta 5}$ mice vs wild-type littermates. Should we have difficulty detecting the anticipated immunoreactivity (i.e., bands at the correct molecular weight), we would attempt immunohistochemistry on lingual tissue, which is less quantitative but should provide some insight into expression levels. Should we find similar levels of T1R1, T1R2, and T1R3 in Rgs21 $1^{\Delta 5 / \Delta 5}$ mice vs wild-type littermates, we would then suspect there is desensitization without concomitant downregulation. In such 
a case, we would examine second messenger production (e.g., calcium flux / pulses) in isolated taste cells as detailed below, testing whether there will be decreased second messenger responses observed to T1R2/3-directed sweeteners and T1R1/3-directed umami compounds if desensitization is occurring.

4.2.2d. Perform second messenger production and ATP release assays in Type II taste cells to determine whether changes in taste perception arise from altered tastant $\overline{G P C R}$ signal transduction outputs

Rationale: Mice made deficient in expression of the ectonucleotidase NTPDase2 exhibit elevated extracellular ATP levels in their taste buds but blunted gustatory nerve output, likely due to desensitized P2X receptors on the sensory afferent (Vandenbeuch et al., 2013). Rgs $21^{\Delta 5 / \Delta 5}$ mice also exhibit blunted gustatory nerve responses to bitter, sweet, and umami taste stimuli (Figure 2.6). Our initial hypothesis is that RGS21 loss throughout development of the tastant-responsive cell (and resultant loss of its negative regulatory function on tastant signaling; Figure 4.1 middle) has led over time to desensitization and/or downregulation of tastant GPCRs and/or support machinery (Figure 4.1 right). However, RGS protein loss may cause elevated ATP release and desensitization of the afferent nerve (Figure 4.2), as suspected in NTPDase2-null mice (Vandenbeuch et al., 2013). Therefore, we would measure second messenger production and ATP release to ascertain the hierarchical level of deficit in the peripheral taste response. In the event our main hypothesis is correct (Figure 4.1), we would observe blunted second messenger production and ATP release in $R g s 21^{\Delta 5 / \Delta 5}$ mice resulting from diminished signaling by tastants at the level of the Type II cell; alternatively, if second messenger production and ATP release is actually elevated in $\operatorname{Rgs} 21^{\Delta 5 / \Delta 5}$ mice, this would lend more credence to the notion of desensitization at the 
level of gustatory nerve P2X receptors (Figure 4.2). Similar studies would also need to be performed with RGS7- and RGS12-null mice.

Methods: (a) Given that ATP is one of the most important taste cell neurotransmitters released by Type II cells upon tastant interaction (Bo et al., 1999; Finger et al., 2005; Vandenbeuch et al., 2015b; Roper and Chaudhari, 2017), we would quantify bitterantinduced ATP release by circumvallate (CV) papillae using established protocols of Dr. Vandenbeuch and colleagues (Finger et al., 2005; Vandenbeuch et al., 2013; Larson et al., 2015). Briefly, lingual epithelium patches containing the circumvallate papilla would be peeled from each tongue of Rgs-deficient and wild-type mice after enzymatic treatment with a mix of dispase $\|(3 \mathrm{mg} / \mathrm{mL}$; Roche) and elastase $(2.5 \mathrm{mg} / \mathrm{mL}$; Worthington) for $18 \mathrm{~min}$. These tissue pieces would then be placed in a modified Ussing chamber $(42 \mu \mathrm{L})$ with the basolateral part of the papilla bathed in Tyrode's solution (Finger et al., 2005; Vandenbeuch et al., 2013; Larson et al., 2015). The apical part of the papilla would be exposed for 3 min to artificial saliva (Vandenbeuch et al., 2013; Larson et al., 2015) and then stimulated with $5 \mu \mathrm{L}$ of a bitter mix (10 mM denatonium + $100 \mu \mathrm{m}$ cycloheximide) diluted in artificial saliva. The bathing solution would then be transferred to a 96-well plate and placed in a plate reader (FlexStation 3). An equal amount of luciferase (ATP Bioluminescence Kit HS II; Roche) would be added to the transferred bathing solution aliquot via an internal injector and luminescence readings taken immediately. Results measured as relative light units would be converted to ATP concentrations with a standard curve obtained from known ATP concentrations run on the same day and in the same final buffer. Experiments would be performed on six Rgsdeficient mice and six wild-type littermate controls; these numbers were found adequate 
for meaningful comparisons in past studies of other knockout strains (Vandenbeuch et al., 2013; Larson et al., 2015). A paired Student's t-test would be used to compare ATP release with artificial saliva vs bitter mix, whereas an unpaired t-test would be used to compare ATP release from Rgs-deficient vs wild-type mice. Results would be analyzed using two-way repeated measures ANOVA (genotype $\times$ stimulus) with Tukey's post hoc test (Prism 7).

Considerations in measuring tastant-induced ATP release -- Papilla ex vivo preparations are highly sensitive to mechanical stimulation (i.e., an independent means of evoking ATP release (Grygorczyk and Hanrahan, 1997)); thus, in these assays, the artificial saliva would not be rinsed from the tongue but instead the bitter mix would be added to the artificial saliva already present (consistent with prior studies (Vandenbeuch et al., 2013; Larson et al., 2015)). Assays would initially be restricted to bitterantinduced ATP release, as our experience to-date suggests that sweeteners do not elicit significant amounts of extracellular ATP from ex vivo preparations for adequate quantitation. Limited responsiveness to sweeteners likely results from disruption of the elaborate ectodomain of the T1R2/T1R3 heterodimer (Montmayeur et al., 2001; Nelson et al., 2001; Cui et al., 2006) upon enzymatic treatment required to isolate the epithelium; bitterant $\mathrm{T} 2 \mathrm{R}$ receptors do not have this elaborate $\mathrm{N}$-terminal ectodomain architecture (Chandrashekar et al., 2000; Singh et al., 2011).

(b) Given that calcium release is well established as a second messenger proximal to activation of T1R and T2R GPCRs (Akabas et al., 1988; Hwang et al., 1990; Huang et al., 1999; Zhang et al., 2003), we would also quantify calcium flux in isolated primary taste cells of Rgs-deficient and wild-type mice immediately after tastant exposure, using 
established protocols (Huang et al., 2005, 2007, 2011; Roberts et al., 2009). To isolate taste cells, a mix of $1 \mathrm{mg} / \mathrm{ml}$ collagenase A, $2.5 \mathrm{mg} / \mathrm{ml}$ dispase II, and $1 \mathrm{mg} / \mathrm{ml}$ trypsin inhibitor in modified Tyrode's buffer (Roberts et al., 2009) would be injected under the circumvallate and foliate papillae. After $25 \mathrm{~min}$ at room temperature, the lingual epithelium, enriched in taste buds, would be peeled away and immediately incubated in modified Tyrode's buffer with $2 \mathrm{mM}$ EGTA for $15 \mathrm{~min}$ and then returned to modified Tyrode's buffer. Taste buds and cells would then be drawn into glass pipettes with gentle suction and transferred to glass coverslips, pre-coated with Cell-Tak (Corning) to hold cells firmly in place. Isolated taste buds and cells would then be loaded with $4 \mu \mathrm{M}$ Fura-2AM for 30 min at room temperature and washed in modified Tyrode's buffer for 30 min. Taste buds and cells would then be mounted on an Nikon TE2000-S Eclipse inverted scope (WVU Imaging Facility) with Prior filter wheels, a Photometrics Coolsnap HQ CCD camera, an Eppendorf FemtoJet microinjector, and MetaMorph / MetaFluor software for calcium ratiometric image acquisition. Images of cells exposed to tastantcontaining (and nominally $\mathrm{Ca}^{2+}$ - and $\mathrm{Mg}^{2+}$-free) modified Tyrode's buffer would be captured at $0.1 \mathrm{~Hz}$ using sequential excitation at 340 and $380 \mathrm{~nm}$ and a longpass ( $\geq 510$ $n m)$ emission filter. The ratio of emission intensities $\left(F_{340} / F_{380}\right)$ would be calculated and $\mathrm{Ca}^{2+}$ transients plotted as the ratio $F_{340} / F_{380}$ minus the mean ratio for $100 \mathrm{~s}$ before each stimulus (pre-stimulus baseline). Peak values above pre-stimulus baseline $\left(i \Delta F_{340} / F_{380}\right)$ would be used to assess statistical significance (two-tailed $t$-tests and/or ANOVA) using Prism 7.

(c) Given that cAMP changes are also observed upon activation of T1R and T2R GPCRs (Abaffy et al., 2003; Caicedo et al., 2003; Trubey et al., 2006; Roper and 
Chaudhari, 2017), we would also quantify cAMP levels in isolated primary taste cells of Rgs-deficient mice and wild-type littermates, both before and after exposure to tastants, using established procedures (Abaffy et al., 2003; Trubey et al., 2006). Briefly (and as described above), taste bud-enriched circumvallate epithelia from Rgs-deficient mice and wild-type littermates would be enzymatically delaminated, dissected free of adjacent non-taste epithelium, and then lysed to extract cAMP into a soluble supernatant and total cAMP in each tissue sample measured using an enzyme immunoassay ("cAMP Direct Biotrak EIA", GE Healthcare). Total protein in each sample would be quantified with NanoOrange protein quantification fluorescence reagent (Fisher), and cAMP amounts would be normalized to total protein content.

Alternatives: If required, we would also investigate quench-flow kinetic analyses for quantifying $\mathrm{IP}_{3}$ in isolated primary taste cells of Rgs-deficient mice and wild-type littermates after exposure to tastants, using published methods (Striem et al., 1991). Papillae and nongustatory control tissue from both genotypes would be freshly prepared and kept at $4^{\circ} \mathrm{C}$ before quench-flow tests; we would use a Horiba Fluorolog 3 spectrofluorometer with pneumatically driven SFA-20/SPEX stopped-flow accessories for rapid kinetic acquisitions, as provided by WVU Biochemistry colleague David Smith (Kim et al., 2015) and following quench-flow parameters/conditions previously described (Spielman et al., 1996).

4.2.2e. Interrogating the role of RGS21, and possibly RGS7 and/or RGS12, in salt taste Overall rationale: Contrary to our initial hypothesis, $\operatorname{Rgs} 21^{\Delta 5 / \Delta 5}$ mice display a loss of appetitive response towards moderate $\mathrm{NaCl}$ concentrations in two-bottle choice tests 
(37.5 - $150 \mathrm{mM} \mathrm{NaCl}$ [Figure 2.5]). Our findings with $R g s 21^{\Delta 5 / \Delta 5}$ mice bolster a growing, but not universally supported, body of work suggesting GPCR signaling in Type II cells is important in the appetitive response to salts (Damak et al., 2006; Hisatsune et al., 2007; Tordoff et al., 2014). $\mathrm{NaCl}$ may activate a receptor sensitive to $\mathrm{Na}^{+}$on Type II cells or these cells may become active via communication from other salt-sensitive cells. Others have suggested that amiloride-insensitive salt taste is transduced by high salt concentrations co-opting sour- and bitter-responsive cells to stimulate aversive pathways (Oka et al., 2013; Lewandowski et al., 2016), implicating G protein signaling within Type II cells in the aversive response to high salt concentrations (Oka et al., 2013). Because multiple mechanisms have been suggested to serve a role in salt taste, each with overlapping, concentration-specific roles, it is difficult to tease out the role of a particular pathway with a single in vivo assay. Therefore, no single test can provide a full picture of how $\mathrm{NaCl}$ tastes to mice, and so we would employ several techniques to stitch together a fuller picture of salt taste in $\operatorname{Rgs} 21^{\Delta 5 / \Delta 5}$ mice and potentially other Rgsdeficient strains with altered salt taste.

\section{Brief-access salt response}

Rationale: We would assess the brief-access salt response in wild-type and Rgsdeficient mice to determine whether RGS proteins, and G protein-initiated signaling in Type II cells, influence short-term acceptance of $\mathrm{NaCl}$ and related salts. These assays would help tease out the role of RGS proteins and the G protein signaling pathway in Type II taste cells in both aversive and appetitive salt responses, in the absence of postingestive influences. 
Method: Brief-access assay would be performed as outlined above (4.2.2b). To assess aversive salt responses, we would evaluate the brief-access response to $\mathrm{Na}^{+}$salts (i.e., $\mathrm{NaCl}$ and $\mathrm{Na}$-Lactate) and non- $\mathrm{Na}^{+}$salts (i.e., $\mathrm{KCl}, \mathrm{NH}_{4} \mathrm{Cl}$ ), with and without amiloride. These aversive assays would be performed on 3 consecutive days following 22.5 hours of water deprivation, with 1 hour of recovery (ad libitum chow and water) following the 30-min test session. We would also assess salt attraction in the brief-access paradigm (Chandrashekar et al., 2010; Oka et al., 2013) by depleting mice of $\mathrm{Na}^{+}$by injecting the diuretic furosemide $\left(50 \mathrm{mg} / \mathrm{kg}\right.$ ) and providing access to low $\mathrm{Na}^{+}$chow and ad libitum water for 16 hour prior to testing.

Expected Outcomes: Utilizing amiloride and non-sodium salts should inform whether a salt-responsive G protein signaling pathway in Type II cells, which RGS21 (and possibly other RGS proteins) might regulate, is activated via a $\mathrm{Na}^{+}$specific mechanism and/or through communication from other amiloride-sensitive cells. It is possible that the $G$ protein signaling regulated by RGS proteins in Type II cells mediates parts of both the amiloride-sensitive and -insensitive salt taste (Oka et al., 2013; Tordoff et al., 2014). Rgs21-deficient mice (and possibly Rgs7- and Rgs12-deficient mice) are likely to have blunted aversion to high concentrations of $\mathrm{Na}^{+}$and non- $\mathrm{Na}^{+}$salts, as seen in other mice lacking G protein signaling components in Type II cells (Damak et al., 2006; Oka et al., 2013). In response to moderate $\mathrm{NaCl}$ concentrations, Type II cells appear to promote the appetitive response possibly via interactions with neighboring, amiloride-sensitive, $\mathrm{Na}^{+}$-responsive cells (Tordoff et al., 2014). Therefore, we anticipate that $R g s 21^{\Delta 5 / \Delta 5}$ mice will have a blunted attractive response to $\mathrm{NaCl}$ following $\mathrm{Na}^{+}$depletion. 


\section{Chorda tympani and glossopharyngeal nerve responses with salts}

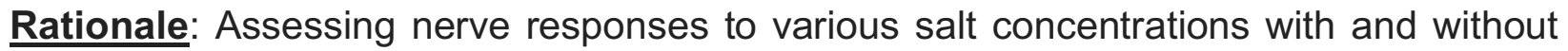
amiloride in Rgs-deficient mice would inform whether the G protein pathway in Type II cells is activated via communication from other $\mathrm{ENaC}+, \mathrm{Na}^{+}$-responsive cell types, as well as inform any concentration-dependent differences in the role of this pathway.

Method: Nerve recordings would be done, as explained above (4.2.1c), to 30, 60, 120 , 300 , and $600 \mathrm{mM} \mathrm{NaCl}$ and additional salts. Amiloride use would show the extent of responses coming from amiloride-sensitive $v s$-insensitive pathways.

Expected outcomes: $R g s 21^{\Delta 5 / \Delta 5}$ mice, and potentially other Rgs-deficient mice, are likely to have blunted nerve responses to moderate and high concentrations of $\mathrm{NaCl}$. We expect amiloride to reduce the nerve response of wild-type mice to those of $\operatorname{Rgs} 21^{\Delta 5 / \Delta 5}$ mice at moderate concentrations of $\mathrm{NaCl}$, but not at high concentrations of $\mathrm{NaCl}$, i.e., supporting the hypothesis that $\mathrm{G}$ protein signaling in Type II cells contributes to amiloride-sensitive tasting of moderate salt concentrations and amiloride-insensitive tasting of high salt concentrations.

Pitfalls and alternatives: Potential dual roles that G protein signaling in Type II cells exert on amiloride-sensitive and -insensitive salt taste make it difficult to get a clear picture of one without the influence of the other. Using several approaches as described above will help tease out these intertwined roles. It is possible that some of the appetitive $\mathrm{NaCl}$ response in two-bottle tests results from altered post-ingestive or physiological influences (e.g., blood pressure) (Bachmanov et al., 1998). However, RGS21 has restricted expression to taste-responsive tissue (von Buchholtz et al., 2004; Cohen et al., 2012; Kimple et al., 2014). Nonetheless, additional nerve recordings of salt 
responses will help determine whether the phenotype seen in two-bottle choice assays is the result of altered peripheral taste signaling. An alternative way to isolate the role of RGS21 in the appetitive salt response would be to generate and breed Tas1r3::Cre mice with Rgs $21^{\text {floxfllox }}$ mice, thereby excising Rgs 21 in only those Type II cells mediating appetitive tastes (i.e., sweet, umami). Such a study would determine whether the blunted appetitive response to moderate $\mathrm{NaCl}$ concentrations found in global Rgs21-null mice is the result of G protein signaling specifically in T1R3+ cells. It would also address confusion that may arise from potentially opposing roles of RGS21 in both appetitive and aversive salt taste. 


\section{3 - References}

Abaffy T, Trubey KR, Chaudhari N (2003) Adenylyl cyclase expression and modulation of cAMP in rat taste cells. Am J Physiol Cell Physiol 284:1420-1428.

Adler E, Hoon MA, Mueller KL, Chandrashekar J, Ryba NJ, Zuker CS (2000) A novel family of mammalian taste receptors. Cell 100:693-702.

Aguado C, Orlandi C, Fajardo-Serrano A, Gil-Minguez M, Martemyanov KA, Luján R (2016) Cellular and Subcellular Localization of the RGS7/Gß5/R7BP Complex in the Cerebellar Cortex. Front Neuroanat 10:114.

Akabas MH, Dodd J, Al-Awqati Q (1988) A bitter substance induces a rise in intracellular calcium in a subpopulation of rat taste cells. Science 242:1047-1050. Anderson GR, Cao Y, Davidson S, Truong H V, Pravetoni M, Thomas MJ, Wickman K, Giesler GJ, Martemyanov KA (2010) R7BP Complexes With RGS9-2 and RGS7 in the Striatum Differentially Control Motor Learning and Locomotor Responses to Cocaine. Neuropsychopharmacology 35:1040-1050.

Anderson GR, Posokhova E, Martemyanov KA (2009) The R7 RGS Protein Family: Multi-Subunit Regulators of Neuronal G Protein Signaling. Cell Biochem Biophys 54:33-46.

Bachmanov AA, Beauchamp GK, Tordoff MG (2002) Voluntary consumption of $\mathrm{NaCl}$, $\mathrm{KCl}, \mathrm{CaCl} 2$, and $\mathrm{NH} 4 \mathrm{Cl}$ solutions by 28 mouse strains. Behav Genet 32:445-457. Bachmanov AA, Schlager G, Tordoff MG, Beauchamp GK (1998) Consumption of electrolytes and quinine by mouse strains with different blood pressures. Physiol Behav 64:323-330. 
Bachmanov AA, Tordoff MG, Beauchamp GK (2008) Sweetener preference of C57BL/6ByJ and 129P3/J mice. Chem Senses 33:681-682.

Barann M, Göthert M, Bönisch H, Dybek A, Urban BW (1997) 5-HT3 receptors in outside-out patches of N1E-115 neuroblastoma cells: basic properties and effects of pentobarbital. Neuropharmacology 36:655-664.

Barann M, Meder W, Dorner Z, Brüss M, Bönisch H, Göthert M, Urban BW (2000) Recombinant human 5-HT3A receptors in outside-out patches of HEK 293 cells: basic properties and barbiturate effects. Naunyn Schmiedebergs Arch Pharmacol 362:255-265.

Barlow LA (2015) Progress and renewal in gustation: new insights into taste bud development. Development 142:3620-3629.

Berman DM, Wilkie TM, Gilman AG (1996) GAIP and RGS4 Are GTPase-Activating Proteins for the Gi Subfamily of G Protein a Subunits. Cell 86:445-452.

Bo X, Alavi A, Xiang Z, Oglesby I, Ford A, Burnstock G (1999) Localization of ATPgated P2X2 and P2X3 receptor immunoreactive nerves in rat taste buds. Neuroreport 10:1107-1111.

Boughter JD, Raghow S, Nelson TM, Munger SD (2005) Inbred mouse strains $\mathrm{C} 57 \mathrm{BL} / 6 \mathrm{~J}$ and DBA/2J vary in sensitivity to a subset of bitter stimuli. BMC Genet $6: 36$

Brûlet P, Babinet C, Kemler R, Jacob F (1980) Monoclonal antibodies against trophectoderm-specific markers during mouse blastocyst formation. Proc Natl Acad Sci 77:4113-4117. 
Bufe B, Hofmann T, Krautwurst D, Raguse J-D, Meyerhof W (2002) The human

TAS2R16 receptor mediates bitter taste in response to $\beta$-glucopyranosides. Nat Genet 32:397-401.

Caicedo A, Pereira E, Margolskee RF, Roper SD (2003) Role of the G-protein subunit alpha-gustducin in taste cell responses to bitter stimuli. J Neurosci 23:9947-9952.

Cao Y, Pahlberg J, Sarria I, Kamasawa N, Sampath AP, Martemyanov KA (2012)

Regulators of G protein signaling RGS7 and RGS11 determine the onset of the light response in ON bipolar neurons. Proc Natl Acad Sci 109:7905-7910.

Chandrashekar J, Kuhn C, Oka Y, Yarmolinsky DA, Hummler E, Ryba NJP, Zuker CS (2010) The cells and peripheral representation of sodium taste in mice. Nature 464:297-301.

Chandrashekar J, Mueller KL, Hoon MA, Adler E, Feng L, Guo W, Zuker CS, Ryba NJP (2000) T2Rs Function as Bitter Taste Receptors. Cell 100:703-711.

Cheever ML, Snyder JT, Gershburg S, Siderovski DP, Harden TK, Sondek J (2008) Crystal structure of the multifunctional Gß5-RGS9 complex. Nat Struct Mol Biol 15:155-162.

Clapp TR, Medler KF, Damak S, Margolskee RF, Kinnamon SC (2006) Mouse taste cells with $\mathrm{G}$ protein-coupled taste receptors lack voltage-gated calcium channels and SNAP-25. BMC Biol 4:1-9.

Clapp TR, Yang R, Stoick CL, Kinnamon SC, Kinnamon JC (2004) Morphologic characterization of rat taste receptor cells that express components of the phospholipase C signaling pathway. J Comp Neurol 468:311-321. 
Cohen SP, Buckley BK, Kosloff M, Garland AL, Bosch DE, Cheng G, Radhakrishna H, Brown MD, Willard FS, Arshavsky VY, Tarran R, Siderovski DP, Kimple AJ (2012) Regulator of G-protein signaling-21 (RGS21) is an inhibitor of bitter gustatory signaling found in lingual and airway epithelia. J Biol Chem 287:41706-41719.

Cui M, Jiang P, Maillet E, Max M, Margolskee RF, Osman R (2006) The heterodimeric sweet taste receptor has multiple potential ligand binding sites. Curr Pharm Des $12: 4591-4600$.

Damak S, Rong M, Yasumatsu K, Kokrashvili Z, Pérez CA, Shigemura N, Yoshida R, Mosinger B, Glendinning JI, Ninomiya Y, Margolskee RF (2006) Trpm5 null mice respond to bitter, sweet, and umami compounds. Chem Senses 31:253-264.

Dando R, Dvoryanchikov G, Pereira E, Chaudhari N, Roper SD (2012) Adenosine enhances sweet taste through A2B receptors in the taste bud. J Neurosci 32:322330.

Fajardo-Serrano A, Wydeven N, Young D, Watanabe M, Shigemoto R, Martemyanov KA, Wickman K, Luján R (2013) Association of Rgs7/G $\beta 5$ complexes with Girk channels and GABAB receptors in hippocampal CA1 pyramidal neurons. Hippocampus 23:1231-1245.

Ferkey DM, Hyde R, Haspel G, Dionne HM, Hess HA, Suzuki H, Schafer WR, Koelle MR, Hart AC (2007) C. elegans G Protein Regulator RGS-3 Controls Sensitivity to Sensory Stimuli. Neuron 53:39-52.

Finger TE, Danilova V, Barrows J, Bartel DL, Vigers AJ, Stone L, Hellekant G, Kinnamon SC (2005) ATP Signaling Is Crucial for Communication from Taste Buds 
to Gustatory Nerves. Science 310:1495-1499.

Freedman NJ, Lefkowitz RJ (1996) Desensitization of G protein-coupled receptors.

Recent Prog Horm Res 51:319-353.

Garzón J, Rodríguez-Díaz M, López-Fando A, Sánchez-Blázquez P (2001) RGS9

proteins facilitate acute tolerance to mu-opioid effects. Eur J Neurosci 13:801-811.

Glendinning Jl, Gresack J, Spector AC (2002) A high-throughput screening procedure

for identifying mice with aberrant taste and oromotor function. Chem senses

27:461-474.

Gross JD, Kaski SW, Schroer AB, Wix KA, Siderovski DP, Setola V (2018) Regulator of

G protein signaling-12 modulates the dopamine transporter in ventral striatum and locomotor responses to psychostimulants. J Psychopharmacol 32.

Grygorczyk R, Hanrahan JW (1997) CFTR-independent ATP release from epithelial cells triggered by mechanical stimuli. Am J Physiol 272:C1058-C1066.

Hisatsune C, Yasumatsu K, Takahashi-Iwanaga H, Ogawa N, Kuroda Y, Yoshida R, Ninomiya Y, Mikoshiba K (2007) Abnormal taste perception in mice lacking the type 3 inositol 1,4,5-trisphosphate receptor. J Biol Chem 282:37225-37231.

Holstein-rathlou S Von et al. (2016) FGF21 Mediates Endocrine Control of Simple

Sugar Intake and Sweet Taste Preference by the Liver. Cell Metab 23:335-343.

Hoon MA, Northup JK, Margolskee RF, Ryba NJ (1995) Functional expression of the taste specific G-protein, alpha-gustducin. Biochem J 309:629-636.

Houpt TA, Frankmann SP (1996) TongueTwister: an integrated program for analyzing lickometer data. Physiol Behav 60:1277-1283. 
Huang L, Shanker YG, Dubauskaite J, Zheng JZ, Yan W, Rosenzweig S, Spielman AI, Max M, Margolskee RF (1999) Gy13 colocalizes with gustducin in taste receptor cells and mediates IP3 responses to bitter denatonium. Nat Neurosci 2:1055-1062.

Huang Y-J, Maruyama Y, Lu K-S, Pereira E, Plonsky I, Baur JE, Wu D, Roper SD (2005) Mouse Taste Buds Use Serotonin as a Neurotransmitter. J Neurosci 25:843-847.

Huang YA, Roper SD (2010) Intracellular Ca2+ and TRPM5-mediated membrane depolarization produce ATP secretion from taste receptor cells. J Physiol 588:2343-2350.

Huang YA, Stone LM, Pereira E, Yang R, Kinnamon JC, Dvoryanchikov G, Chaudhari N, Finger TE, Kinnamon SC, Roper SD (2011) Knocking Out P2X Receptors Reduces Transmitter Secretion in Taste Buds. J Neurosci 31:13654-13661. Huang Y, Dando R, Roper S (2009) Autocrine and paracrine roles for ATP and serotonin in mouse taste buds. J Neurosci 29:13909-13918.

Huang YJ, Maruyama Y, Dvoryanchikov G, Pereira E, Chaudhari N, Roper SD (2007) The role of pannexin 1 hemichannels in ATP release and cell-cell communication in mouse taste buds. Proc Natl Acad Sci 104:6436-6441.

Hwang I-Y, Park C, Harrison K, Boularan C, Galés C, Kehrl JH (2015) An Essential Role for RGS Protein/Gai2 Interactions in B Lymphocyte-Directed Cell Migration and Trafficking. J Immunol 194:2128-2139.

Hwang PM, Verma A, Bredt DS, Snyder SH (1990) Localization of phosphatidylinositol signaling components in rat taste cells: role in bitter taste transduction. Proc Natl 
Acad Sci 87:7395-7399.

Ishida Y, Ugawa S, Ueda T, Yamada T, Shibata Y, Hondoh A, Inoue K, Yu Y, Shimada S (2009) P2X2- and P2X3-positive fibers in fungiform papillae originate from the chorda tympani but not the trigeminal nerve in rats and mice. J Comp Neurol $514: 131-144$.

Jenkins A, Franks NP, Lieb WR (1996) Actions of general anaesthetics on 5-HT3 receptors in N1E-115 neuroblastoma cells. Br J Pharmacol 117:1507-1515.

Kataoka S, Baquero A, Yang D, Shultz N, Vandenbeuch A, Ravid K, Kinnamon SC, Finger TE (2012) A2BR adenosine receptor modulates sweet taste in circumvallate taste buds. PLoS One 7:e30032.

Kilkenny C, Browne WJ, Cuthill IC, Emerson M, Altman DG (2010) Improving Bioscience Research Reporting: The ARRIVE Guidelines for Reporting Animal Research. PLoS Biol 8:e1000412.

Kim Y-C, Snoberger A, Schupp J, Smith DM (2015) ATP binding to neighbouring subunits and intersubunit allosteric coupling underlie proteasomal ATPase function. Nat Commun 6:8520.

Kimple AJ, Bosch DE, Giguère PM, Siderovski DP (2011) Regulators of G-protein signaling and their Ga substrates: promises and challenges in their use as drug discovery targets. Pharmacolo Rev 63:728-749.

Kimple AJ, Garland AL, Cohen SP, Setola V, Willard FS, Zielinski T, Lowery RG, Tarran R, Siderovski DP (2014) RGS21, a regulator of taste and mucociliary clearance? Laryngoscope 124:E56-E63. 
Kimple RJ, De Vries L, Tronchère H, Behe CI, Morris RA, Farquhar MG, Siderovski DP (2001) RGS12 and RGS14 GoLoco motifs are G alpha(i) interaction sites with guanine nucleotide dissociation inhibitor Activity. J Biol Chem 276:29275-29281.

Kinnamon SC, Finger TE (2013) A taste for ATP: neurotransmission in taste buds. Front Cell Neurosci 7:264.

Kusumakshi S, Voigt A, Hübner S, Hermans-Borgmeyer I, Ortalli A, Pyrski M, Dörr J, Zufall F, Flockerzi V, Meyerhof W, Montmayeur J-P, Boehm U (2015) A Binary Genetic Approach to Characterize TRPM5 Cells in Mice. Chem Senses 40:413425.

Lambert NA, Johnston CA, Cappell SD, Kuravi S, Kimple AJ, Willard FS, Siderovski DP (2010) Regulators of G-protein Signaling accelerate GPCR signaling kinetics and govern sensitivity solely by accelerating GTPase activity. Proc Natl Acad Sci 107:7066-7071.

Laroche G, Giguère PM, Roth BL, Trejo J, Siderovski DP (2010) RNA interference screen for RGS protein specificity at muscarinic and protease-activated receptors reveals bidirectional modulation of signaling. Am J Physiol Cell Physiol 299:C65464.

Larson ED, Vandenbeuch A, Voigt A, Meyerhof W, Kinnamon SC, Finger TE (2015) The Role of 5-HT3 Receptors in Signaling from Taste Buds to Nerves. J Neurosci $35: 15984-15995$.

Lawton DM, Furness DN, Lindemann B, Hackney CM (2000) Localization of the glutamate-aspartate transporter, GLAST, in rat taste buds. Eur J Neurosci 


\section{2:3163-3171.}

Lewandowski BC, Sukumaran SK, Margolskee RF, Bachmanov AA (2016) AmilorideInsensitive Salt Taste Is Mediated by Two Populations of Type III Taste Cells with Distinct Transduction Mechanisms. J Neurosci 36:1942-1953.

Li X, Staszewski L, Xu H, Durick K, Zoller M, Adler E (2002) Human receptors for sweet and umami taste. Proc Natl Acad Sci 99:4692-4696.

Luttrell LM, Lefkowitz RJ (2002) The role of beta-arrestins in the termination and transduction of G-protein-coupled receptor signals. J Cell Sci 115:455-465.

Martin-McCaffrey L, Hains MD, Pritchard GA, Pajak A, Dagnino L, Siderovski DP, D'Souza SJA (2005) Differential expression of regulator of G-protein signaling R12 subfamily members during mouse development. Dev Dyn 234:438-444.

Martin C, Passilly-Degrace P, Gaillard D, Merlin J-F, Chevrot M, Besnard P (2011) The lipid-sensor candidates CD36 and GPR120 are differentially regulated by dietary lipids in mouse taste buds: impact on spontaneous fat preference. PLoS One 6:e24014.

Mistretta CM, Goosens KA, Farinas I, Reichardt LF (1999) Alteration in Size, Number, and Morphology of Gustatory Papillae and Taste Buds in BDNF Null Mutant Mice Demonstrate Neural Dependence of Developing Taste Organs. J Comp Neurol 409:13-24.

Montmayeur JP, Liberles SD, Matsunami H, Buck LB (2001) A candidate taste receptor gene near a sweet taste locus. Nat Neurosci 4:492-498.

Nelson G, Chandrashekar J, Hoon MA, Feng L, Zhao G, Ryba NJP, Zuker CS (2002) 
An amino-acid taste receptor. Nature 416:199-202.

Nelson G, Hoon MA, Chandrashekar J, Zhang Y, Ryba NJ, Zuker CS (2001)

Mammalian sweet taste receptors. Cell 106:381-390.

Nelson TM, LopezJimenez ND, Tessarollo L, Inoue M, Bachmanov AA, Sullivan SL

(2010) Taste Function in Mice with a Targeted Mutation of the Pkd1/3 Gene. Chem Senses 35:565-577.

Neubig RR, Spedding M, Kenakin T, Christopoulos A, International Union of

Pharmacology Committee on Receptor Nomenclature and Drug Classification (2003) International Union of Pharmacology Committee on Receptor Nomenclature and Drug Classification. XXXVIII. Update on Terms and Symbols in Quantitative Pharmacology. Pharmacol Rev 55:597-606.

North RA (2002) Molecular physiology of P2X receptors. Physiol Rev 82:1013-67.

Oka Y, Butnaru M, von Buchholtz L, Ryba NJP, Zuker CS (2013) High salt recruits aversive taste pathways. Nature 494:472-475.

Ostrovskaya O, Xie K, Masuho I, Fajardo-Serrano A, Lujan R, Wickman K, Martemyanov KA (2014) RGS7/Gß5/R7BP complex regulates synaptic plasticity and memory by modulating hippocampal GABABR-GIRK signaling. Elife 3:e02053.

Pérez CA, Huang L, Rong M, Kozak JA, Preuss AK, Zhang H, Max M, Margolskee RF (2002) A transient receptor potential channel expressed in taste receptor cells. Nat Neurosci 5:1169-1176.

Qin Y, Sukumaran SK, Jyotaki M, Redding K, Jiang P, Margolskee RF (2018) Gli3 is a negative regulator of Tas1r3-expressing taste cells Barlow LA, ed. PLOS Genet 
14:e1007058.

Rajagopal S, Shenoy SK (2018) GPCR desensitization: Acute and prolonged phases. Cell Signal 41:9-16.

Roberts CD, Dvoryanchikov G, Roper SD, Chaudhari N (2009) Interaction between the second messengers cAMP and Ca2+ in mouse presynaptic taste cells. J Physiol $587: 1657-1668$.

Roper SD, Chaudhari N (2017) Taste buds: cells, signals and synapses. Nat Rev Neurosci 18:485-497.

Saites LN, Goldsmith Z, Densky J, Guedes VA, Boughter JD (2015) Mice Perceive Synergistic Umami Mixtures as Tasting Sweet. Chem Senses 40:295-303.

Sambi BS, Hains MD, Waters CM, Connell MC, Willard FS, Kimple AJ, Pyne S, Siderovski DP, Pyne NJ (2006) The effect of RGS12 on PDGFbeta receptor signalling to p42/p44 mitogen activated protein kinase in mammalian cells. Cell signal 18:971-981.

Sarria I, Orlandi C, McCall MA, Gregg RG, Martemyanov KA (2016) Intermolecular Interaction between Anchoring Subunits Specify Subcellular Targeting and Function of RGS Proteins in Retina ON-Bipolar Neurons. J Neurosci 36:29152925.

Schroer AB, Gross JD, Kaski SW, Wix K, Siderovski DP, Vandenbeuch A, Setola V (2018) Development of full sweet, umami, and bitter taste responsiveness requires Regulator of G protein Signaling-21 (RGS21). Chem Senses.

Sclafani A, Glendinning Jl (2003) Flavor preferences conditioned in C57BL/6 mice by 
intragastric carbohydrate self-infusion. Physiol Behav 79:783-788.

Sclafani A, Glendinning Jl (2005) Sugar and fat conditioned flavor preferences in C57BL/6J and 129 mice: oral and postoral interactions. Am J Physiol Regul Integr Comp Physiol 289:R712-R720.

Siderovski DP, Willard FS (2005) The GAPs, GEFs, and GDIs of heterotrimeric Gprotein alpha subunits. Int J Biol Sci 1:51-66.

Singh N, Pydi SP, Upadhyaya J, Chelikani P (2011) Structural Basis of Activation of Bitter Taste Receptor T2R1 and Comparison with Class A G-protein-coupled Receptors (GPCRs). J Biol Chem 286:36032-36041.

Snow BE, Betts L, Mangion J, Sondek J, Siderovski DP (1999) Fidelity of G protein beta-subunit association by the G protein gamma-subunit-like domains of RGS6, RGS7, and RGS11. Proc Natl Acad Sci 96:6489-6494.

Snow BE, Hall RA, Krumins AM, Brothers GM, Bouchard D, Brothers CA, Chung S, Mangion J, Gilman AG, Lefkowitz RJ, Siderovski DP (1998) GTPase Activating Specificity of RGS12 and Binding Specificity of an Alternatively Spliced PDZ (PSD95/Dlg/ZO-1) Domain. J Biol Chem 273:17749-17755.

Spielman AI, Nagai H, Sunavala G, Dasso M, Breer H, Boekhoff I, Huque T, Whitney G, Brand JG (1996) Rapid kinetics of second messenger production in bitter taste. Am J Physiol 270:C926-C931.

Stellar E, Hill JH (1952) The rats rate of drinking as a function of water deprivation. J Comp Physiol Psychol 45:96-102.

Striem BJ, Naim M, Lindemann B (1991) Generation of Cyclic AMP in Taste Buds of the 
Rat Circumvallate Papilla in Response to Sucrose. Cell Physiol Biochem 1:46-54.

Sukumaran SK, Lewandowski BC, Qin Y, Kotha R, Bachmanov AA, Margolskee RF

(2017) Whole transcriptome profiling of taste bud cells. Sci Rep 7:7595.

Sutton LP, Ostrovskaya O, Dao M, Xie K, Orlandi C, Smith R, Wee S, Martemyanov KA

(2016) Regulator of G-Protein Signaling 7 Regulates Reward Behavior by

Controlling Opioid Signaling in the Striatum. Biol Psychiatry 80:235-245.

Taruno A, Vingtdeux V, Ohmoto M, Ma Z, Dvoryanchikov G, Li A, Adrien L, Zhao H,

Leung S, Abernethy M, Koppel J, Davies P, Civan MM, Chaudhari N, Matsumoto I,

Hellekant G, Tordoff MG, Marambaud P, Foskett JK (2013) CALHM1 ion channel

mediates purinergic neurotransmission of sweet, bitter and umami tastes. Nature 495:223-226.

Terzi D, Cao Y, Agrimaki I, Martemyanov KA, Zachariou V (2012) R7BP Modulates Opiate Analgesia and Tolerance but not Withdrawal. Neuropsychopharmacology $37: 1005-1012$.

Tordoff MG (2007) Taste Solution Preferences of C57BL/6J and 129X1/SvJ Mice: Influence of Age, Sex, and Diet. Chem Senses 32:655-671.

Tordoff MG, Ellis HT, Aleman TR, Downing A, Marambaud P, Foskett JK, Dana RM, McCaughey SA (2014) Salty taste deficits in CALHM1 knockout mice. Chem Senses 39:515-528.

Trubey KR, Culpepper S, Maruyama Y, Kinnamon SC, Chaudhari N (2006) Tastants evoke cAMP signal in taste buds that is independent of calcium signaling. Am $\mathrm{J}$ Physiol Cell Physiol 291:C237-C244. 
Ugawa S, Yamamoto T, Ueda T, Ishida Y, Inagaki A, Nishigaki M, Shimada S (2003) Amiloride-insensitive currents of the acid-sensing ion channel-2a (ASIC2a)/ASIC2b heteromeric sour-taste receptor channel. J Neurosci 23:3616-3622.

Uhlik MT, Temple B, Bencharit S, Kimple AJ, Siderovski DP, Johnson GL (2005) Structural and evolutionary division of phosphotyrosine binding (PTB) domains. J Mol Biol 345:1-20.

Vandenbeuch A, Anderson CB, Kinnamon SC (2015a) Mice lacking pannexin 1 release ATP and respond normally to all taste qualities. Chem Senses 40:461-467.

Vandenbeuch A, Anderson CB, Parnes J, Enjyoji K, Robson SC, Finger TE, Kinnamon SC (2013) Role of the ectonucleotidase NTPDase2 in taste bud function. Proc Natl Acad Sci 110:14789-14794.

Vandenbeuch A, Larson ED, Anderson CB, Smith SA, Ford AP, Finger TE, Kinnamon SC (2015b) Postsynaptic P2X3-containing receptors in gustatory nerve fibres mediate responses to all taste qualities in mice. J Physiol 593:1113-1125.

von Buchholtz L, Elischer A, Tareilus E, Gouka R, Kaiser C, Breer H, Conzelmann S (2004) RGS21 is a novel regulator of G protein signalling selectively expressed in subpopulations of taste bud cells. Eur J Neurosci 19:1535-1544.

Wang $\mathrm{H}$, Iguchi N, Rong Q, Zhou M, Ogunkorode M, Inoue M, Pribitkin EA, Bachmanov AA, Margolskee RF, Pfeifer K, Huang L (2009) Expression of the voltage-gated potassium channel KCNQ1 in mammalian taste bud cells and the effect of its nullmutation on taste preferences. J Comp Neurol 512:384-398.

Watson N, Linder ME, Druey KM, Kehrl JH, Blumer KJ (1996) RGS family members: 
GTPase-activating proteins for heterotrimeric G-protein alpha-subunits. Nature 383:172-175.

Willard MD, Willard FS, Li X, Cappell SD, Snider WD, Siderovski DP (2007) Selective role for RGS12 as a Ras/Raf/MEK scaffold in nerve growth factor-mediated differentiation. EMBO J 26:2029-2040.

Wong GT, Gannon KS, Margolskee RF (1996) Transduction of bitter and sweet taste by gustducin. Nature 381:796-800.

Woodard GE, Jardín I, Berna-Erro A, Salido GM, Rosado JA (2015) Regulators of GProtein-Signaling Proteins: Negative Modulators of G-Protein-Coupled Receptor Signaling. Int Rev Cell Mol Biol 317:97-183.

Woolf PJ, Linderman JJ (2003) Untangling ligand induced activation and desensitization of G-protein-coupled receptors. Biophys J 84:3-13.

Xie K, Allen KL, Kourrich S, Colón-Saez J, Thomas MJ, Wickman K, Martemyanov KA (2010) Gbeta5 recruits R7 RGS proteins to GIRK channels to regulate the timing of neuronal inhibitory signaling. Nat Neurosci 13:661-663.

Yang R, Crowley HH, Rock ME, Kinnamon JC (2000) Taste cells with synapses in rat circumvallate papillae display SNAP-25-like immunoreactivity. J Comp Neurol 424:205-215.

Zhang Y, Hoon MA, Chandrashekar J, Mueller KL, Cook B, Wu D, Zuker CS, Ryba NJP (2003) Coding of sweet, bitter, and umami tastes: Different receptor cells sharing similar signaling pathways. Cell 112:293-301.

Zhao GQ, Zhang Y, Hoon MA, Chandrashekar J, Erlenbach I, Ryba NJP, Zuker CS 
(2003) The receptors for mammalian sweet and umami taste. Cell 115:255-266.

Zukerman S, Ackroff K, Sclafani A (2011) Rapid post-oral stimulation of intake and flavor conditioning by glucose and fat in the mouse. Am J Physiol Regul Integr Comp Physiol 301:1635-1647. 